\title{
2003 Volcanic Activity in Alaska and Kamchatka: Summary of Events and Response of the Alaska Volcano Observatory
}

by Robert G. McGimsey, Christina A. Neal, and Olga Girina

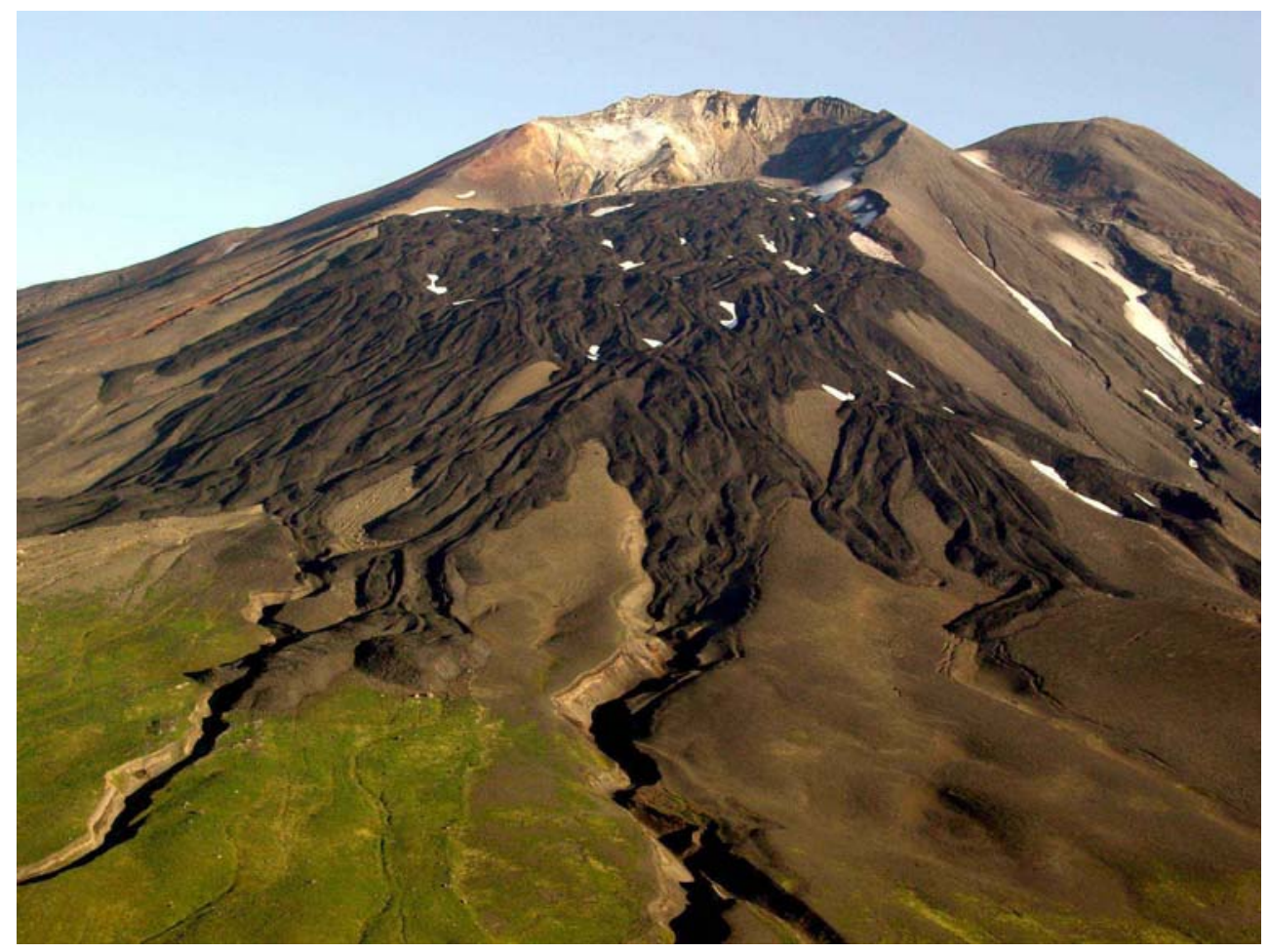

Open-File Report 2005-1310

U.S. Department of the Interior U.S. Geological Survey 


\section{Volcanic Activity in Alaska and Kamchatka: Summary of Events and Response of the Alaska Volcano Observatory}

By Robert G. McGimsey ${ }^{1}$, Christina A. Neal ${ }^{1}$, and Olga Girina ${ }^{2}$

${ }^{1}$ Alaska Volcano Observatory, 4200 University Dr., Anchorage, AK 99508-4664

${ }^{2}$ Kamchatka Volcanic Eruptions Response Team, Institute of Volcanic Geology and Geochemistry, Piip Blvd, 9 PetropavlovskKamchatsky, 683006, Russia

AVO is a cooperative program of the U.S. Geological Survey, University of Alaska Fairbanks Geophysical Institute, and the Alaska Division of Geological and Geophysical Surveys. AVO is funded by the U.S. Geological Survey Volcano Hazards Program and the State of Alaska

Any use of trade, firm, or product names is for descriptive purposes only and does not imply endorsement by the U.S. Government

Open-File Report 2005-1310 


\section{TABLE OF CONTENTS}

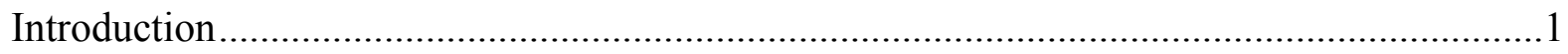

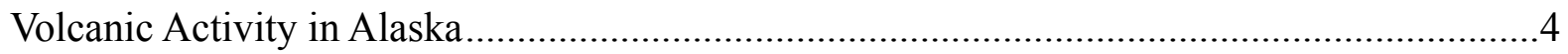

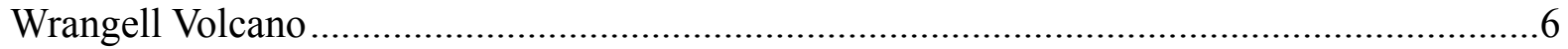

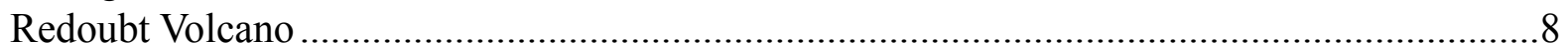

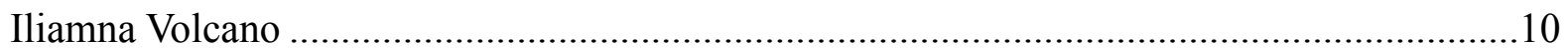

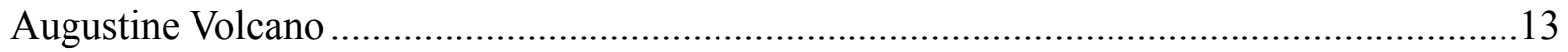

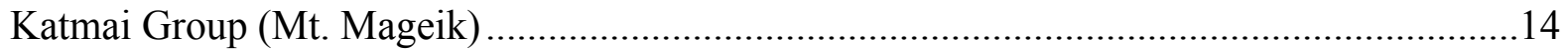

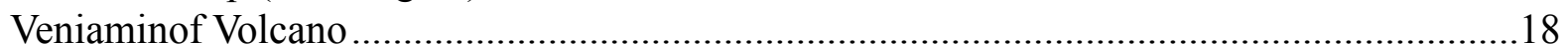

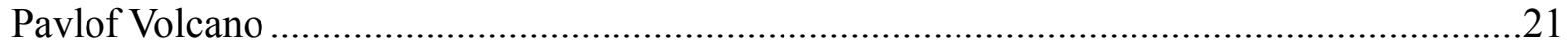

Mt. Hague Vent of Emmons Lake Caldera ...................................................................22

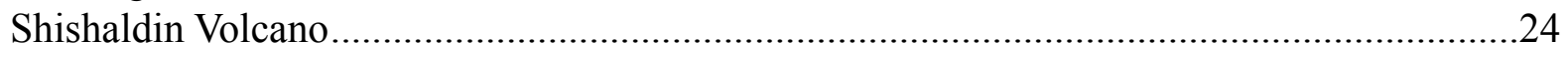

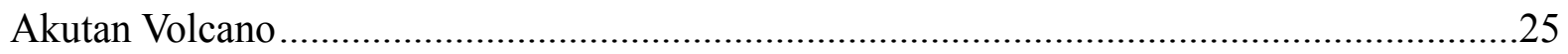

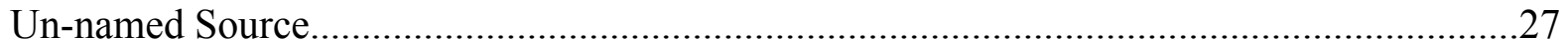

Volcanic activity, Kamchatka Peninsula, and the Northern Kurile Islands, Russia.................28

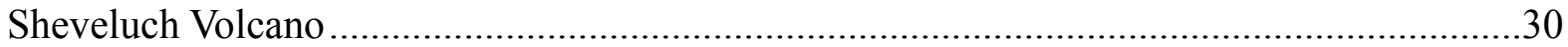

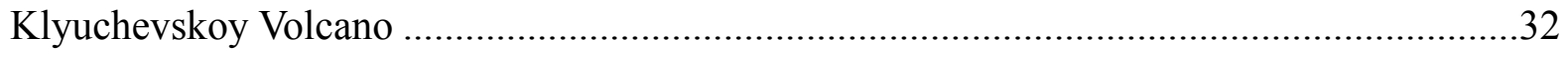

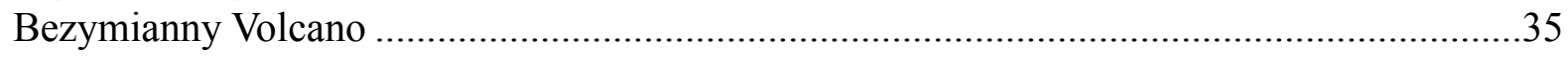

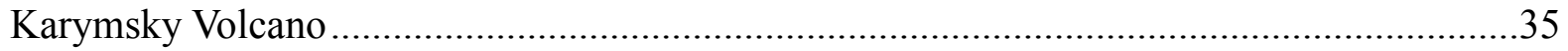

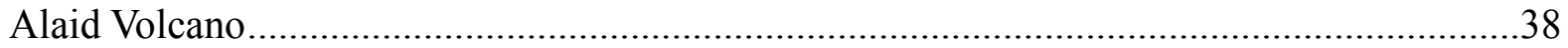

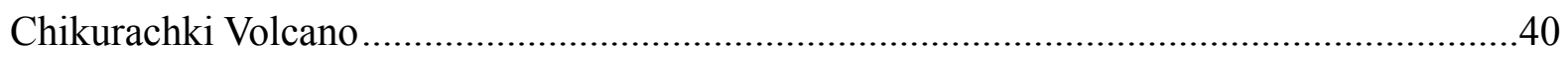

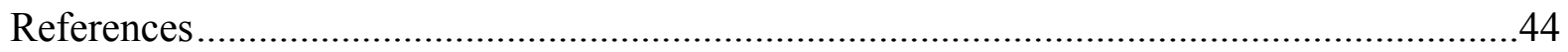

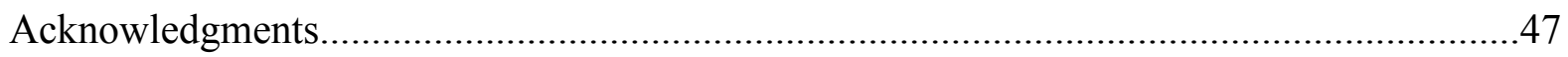

Glossary of Selected Terms and Acronyms (some may not occur in this report) ....................52

Figures

1. Locations of historically active Alaskan volcanoes ..............................................................

2. Volcanoes monitored with a seismic network as of the end of 2003 ................................. 4

3. Location of Kamchatka, Kurile, and Alaska volcanoes and proximity to air routes ............5

4. Anomalous steam or weather cloud over Mount Wrangell.................................................

5. View of Redoubt Volcano from the north ………............................................................

6. Redoubt, Drift River, and oil loading and storage facility ..............................................10

$7 A, B, C$. Fumarole field and avalanches on Iliamna volcano ................................................12

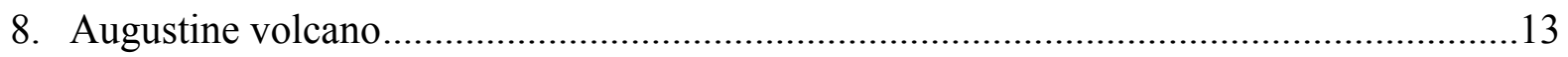

9. Mount Mageik................................................................................................................ 14

10. Satellite view of re-suspended ash forming a cloud over Kodiak Island..........................16

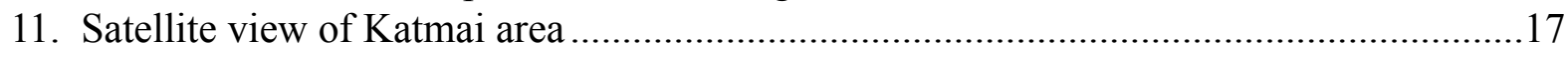

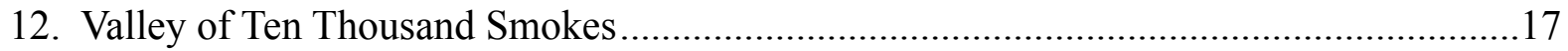


13. Veniaminof caldera

14. Satellite view of Veniaminof caldera and 2002 ash deposit..............................................20

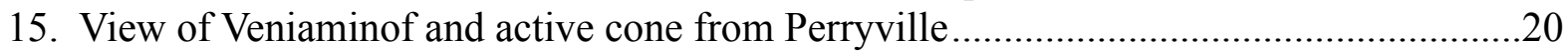

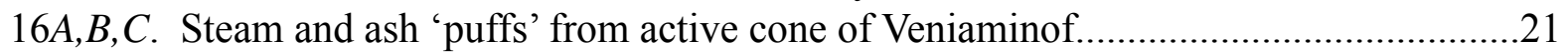

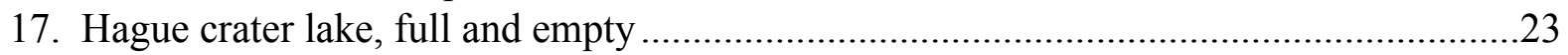

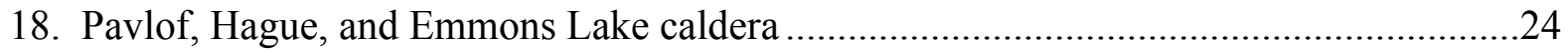

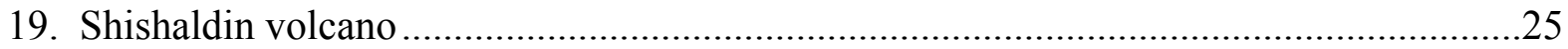

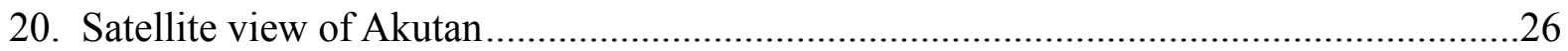

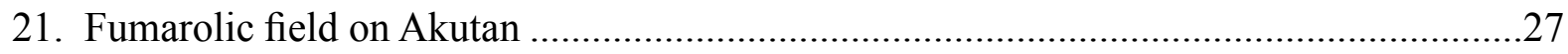

22. Map of the Kamchatka Peninsula and northern Kurile Islands .......................................29

23. A cloud of steam and volcanic gas emanating from Sheveluch Volcano............................31

24. Satellite image of Sheveluch and Klyuchevskoy Group volcanoes in Kamchatka ...........31

25. Small ash explosion above the summit of Klyuchevskoy Volcano ...................................33

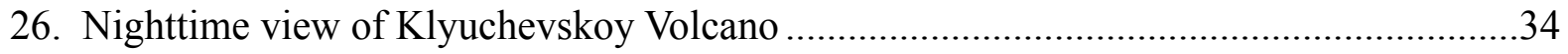

27. Explosive ash plume rising from Karymsky Volcano........................................................36

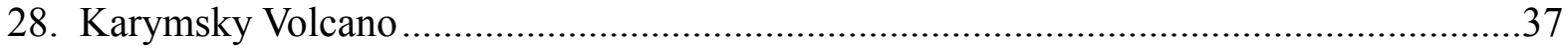

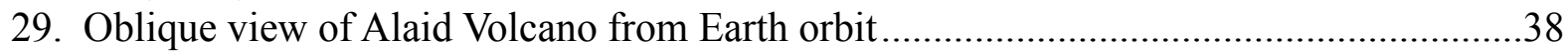

30. Satellite image of ash cloud from 1981 eruption of Alaid Volcano ...................................39

31. Map of northern Kurile Islands and southern portion of Kamchatka Peninsula................40

32. Satellite image of erupting Chikurachki Volcano ……....................................................42

Tables

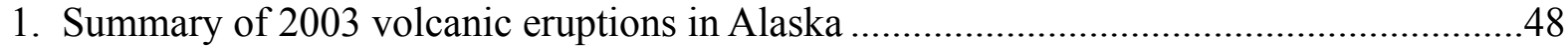

2. Summary of 2003 suspect volcanic events in Alaska .......................................................4

3. Summary of 2003 volcanic activity on Kamchatka Peninsula and Kurile Islands .............49

4. Summary of 2003 suspect volcanic eruptions in Kamchatka and Kurile Islands...............49

5. Chronology of modern seismic and other monitoring of Kamchatka as of Dec. 2003 ......50

6. Level of Concern Color Code for volcanic activity........................................................51

COVER PHOTO: Gareloi Volcano, elevation 5,161 ft. $(1,573 \mathrm{~m})$, in the western Aleutian Islands, Alaska. Levied lava flows from an eruption in the 1980s drape the south flank of the southern crater. Gareloi has erupted about a dozen times since its discovery in 1741. The Alaska Volcano Observatory installed a seismic network and mapped the volcano during the ship-based western Aleutian campaign of 2003. Photo by G. McGimsey, September 25, 2003. 


\section{INTRODUCTION}

The Alaska Volcano Observatory (AVO) monitors the more than 40 historically active volcanoes of the Aleutian Arc. Of these, 24 were considered monitored in real time with shortperiod seismic instrument networks as of the end of 2003 (figs. 1, 2) (Dixon and others, 2004). The AVO core monitoring program also includes daily analysis of satellite imagery, observation over flights, and compilation of pilot reports and reports from local residents and mariners. In 2003 , AVO responded to eruptive activity or suspected volcanic activity at or near 10 volcanic centers (fig. 1; tables 1, 2): Wrangell, Redoubt, Iliamna, Augustine, Mageik, Veniaminof, Pavlof, Emmons Lake (Hague), Shishaldin, and Akutan volcanoes.

In addition to responding to eruptive activity at Alaska volcanoes, AVO assisted in the dissemination of information for the Kamchatka Volcanic Eruption Response Team (KVERT) about the 2003 activity of 6 Russian volcanoes: Sheveluch, Klyuchevskoy, Bezymianny, Karymsky, Alaid, and Chikurachki volcanoes (fig. 22; tables 3,4). Due to prevailing wind directions, erupting Kamchatkan, Kurile Island, and Alaskan volcanoes pose a serious potential threat to aircraft in the North Pacific (fig. 3).

This report summarizes volcanic activity and AVO responses during 2003, as well as information on the reported activity at Russian volcanoes. Only those reports or inquiries that resulted in a "significant" investment of staff time and energy (here defined as several hours or more for reaction, tracking, and follow-up) are included. AVO typically receives dozens of reports throughout the year of steaming, unusual cloud sightings, or eruption rumors. Most of these are resolved quickly and are not tabulated here as part of the 2003 response record. On rare occasions, AVO issues an information release to dispel rumors of volcanic activity, explain a phenomenon, or warn of a non-eruptive hazard; an example of this occurred on Sunday, September 21, 2003 when strong winds in the Katmai area swept ash from the Valley of Ten Thousand Smokes 1912 deposits, forming a large downwind cloud (see fig. 10). Some of the material fell on Kodiak Island and was mistaken by locals for ash from a volcanic eruption. The phrase "suspect volcanic activity" (SVA), used to characterize several responses, is an eruption report or report of unusual activity that is subsequently determined to be normal or enhanced fumarolic activity, weatherrelated phenomena, or a non-volcanic event. A good example in 2003 was an advisory issued by Alaska Aviation Weather Unit (AAWU) warning of an ash cloud at 35,000 ft (10,670 m) moving across North Pacific Air Corridor routes. AVO's rapid response and analysis of satellite data revealed the cloud was meteorological in origin (this report).

The Catalog of Active Volcanoes of the World (CAVW) numbers are provided for referencing the Smithsonian Institution files (Simkin and Siebert, 1994). Descriptions of volcanic activity and AVO responses are presented in geographical order from northeast to southwest along the Aleutian volcanic arc. All elevations reported are above sea level (ASL) unless noted, and time is reported as Alaska Standard Time (AST), Alaska Daylight Time (ADT), Kamchatka Standard Time (KST), or Kamchatka Daylight Time (KDT) (see glossary). We have chosen to preserve English units of measurements when used in primary observations of distance or elevation such as those commonly received via pilot reports and aviation authorities in the United States. A summary of volcanic activity is presented in Table 1. SVA that required significant responses are summarized in Table 2. Table 3 summarizes volcanic activity and responses in Kamchatka. Information about 2003 responses is compiled from AVO weekly updates and information releases, 
internal bimonthly reports, the AVO 2003 "Chron book" - a chronological collection of daily or weekly staff notes for a particular year-and the Smithsonian Institution Global Volcanism Network Bulletin $(\mathrm{GVN})$, which uses AVO as the source for reports on Alaska volcanoes.

AVO's response to reported remote volcanic activity varies depending on the source and content of the observation. After receiving a report and possibly conducting a follow-up investigation of the factual information, AVO usually contacts the National Weather Service (NWS) and Federal Aviation Administration (FAA) or local residents for corroboration and/or formal notification. For a verified significant eruption or unrest, an established call-down procedure is initiated to formally notify other government agencies, air carriers, facilities at risk, and the media. If an eruption or unrest is no longer suspected, appropriate notification calls are made and a notation is made in AVO files. A special information release may be distributed if eruptive activity is confirmed, and the events are further summarized in the AVO weekly update distributed each Friday via electronic mail and facsimile.

AVO's definition of an 'historically active' volcano is one for which written records exist of significant unrest or eruptive activity. Prior to the Russian arrival in Alaska in 1741, accounts of volcanic activity were passed down by native oral traditions; no written records existed. By the mid-1700s, Russian explorers and fur trappers began plying Alaskan waters with regularity and records of volcanic activity began to appear in ships' logs, captains' diaries, and scientific publications and notes. Thus, of the more than 80 volcanic centers spread across the Aleutian Arc, Alaska Peninsula, and a few other remote locations in Alaska, only 41 have documented historical activity. On figure 1 we include several volcanoes (italicized) that do not meet this criteria, but which have been deemed potentially active based on documented volcanic activity within the past several thousand years. A good example is Mt. Churchill, located in eastern Alaska [\#1 on figure 1], which is the source of the two of the most voluminous eruptions on earth in the last 2,000 years, but which has had no historical activity (McGimsey and others, 1992; Richter and others, 1995a).

For information about any of Alaska's volcanoes, please visit the AVO website at http:// www.avo.alaska.edu. 


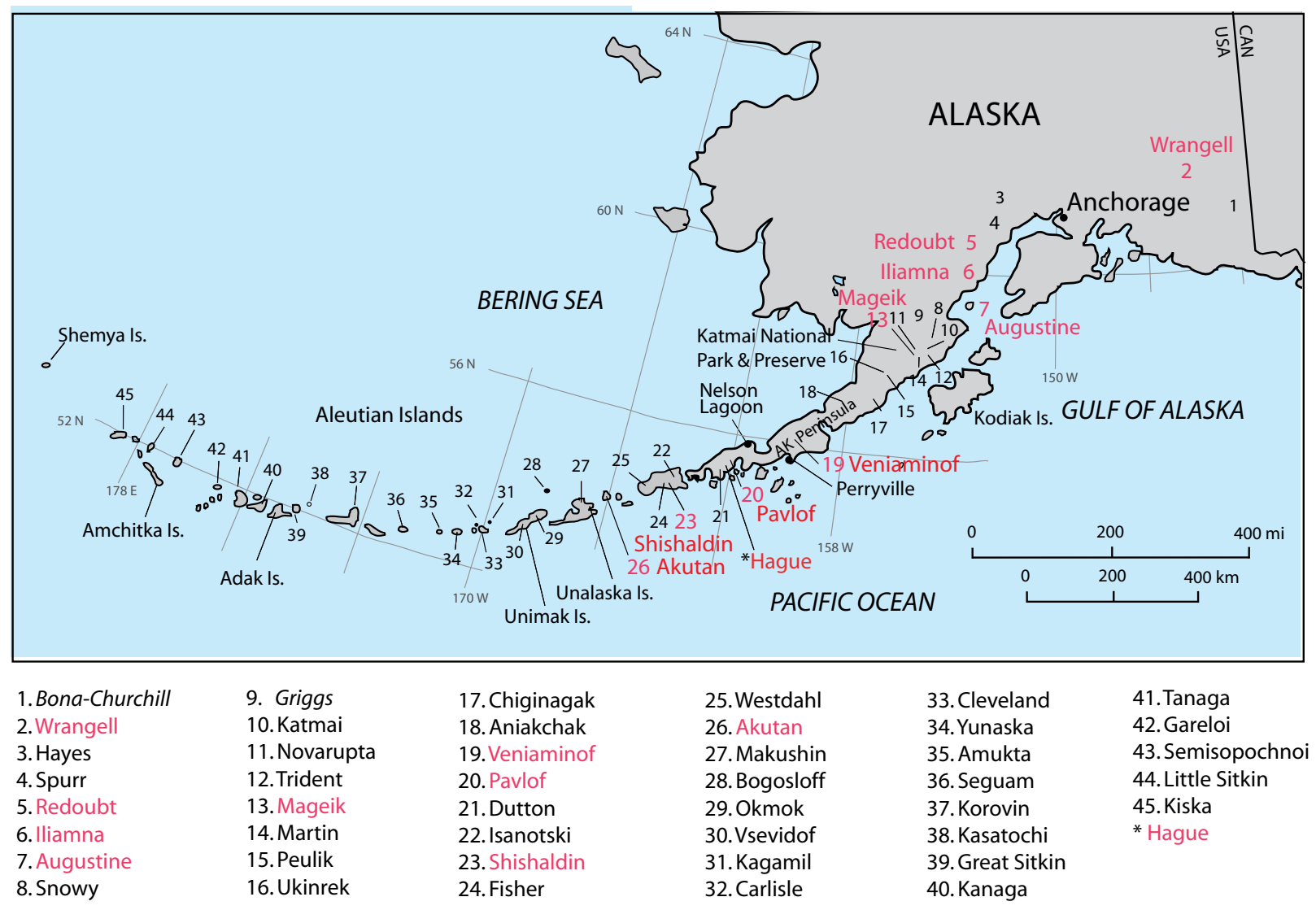

Figure 1. Location of historically active volcanoes in Alaska and place names used in this summary. Volcanoes mentioned in this report are in bold red. Volcanoes with no documented historical unrest but currently considered hazardous based on late-Holocene eruptive activity are italicized. 


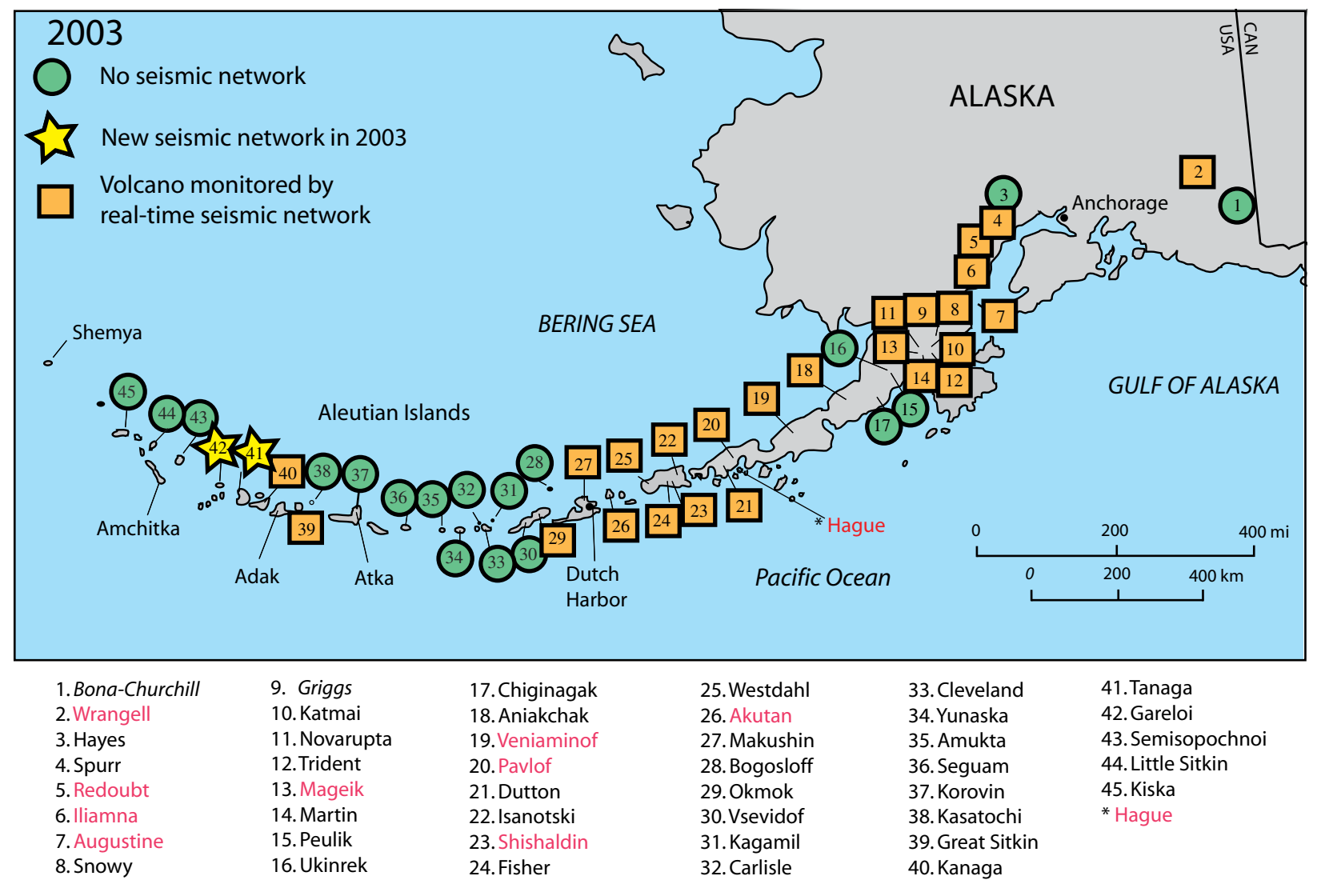

Figure 2. Map showing those volcanoes monitored with a seismic network as of the end of 2003. Volcanoes with no documented historical unrest but currently hazardous based on late-Holocene eruptive activity are footnoted. Volcanoes mentioned in this report shown in bold red. 


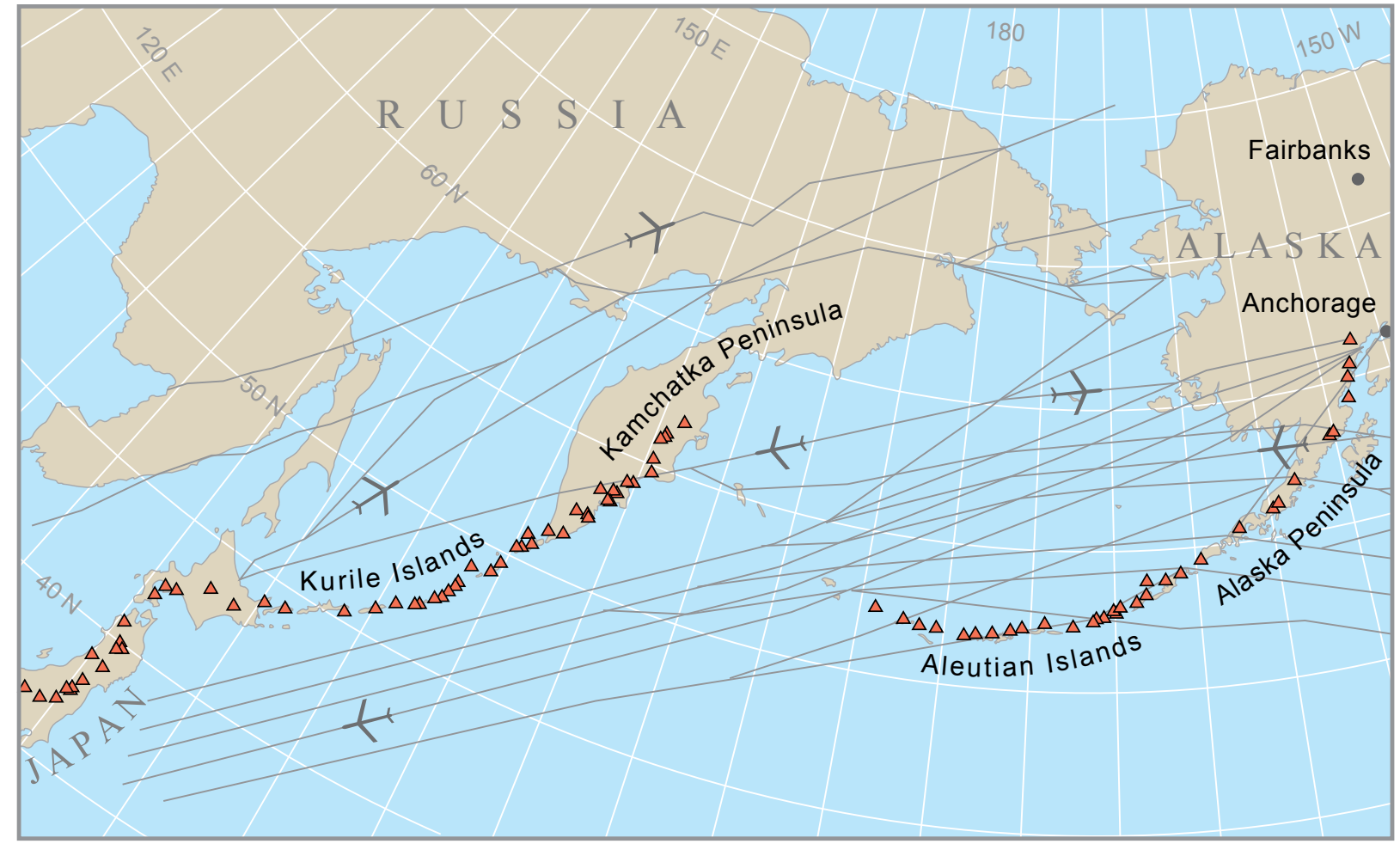

Figure 3. Location of Russian and Alaska volcanoes and their proximity to North Pacific and Russian Far East air routes. 


\section{VOLCANIC ACTIVITY, NORTHEAST TO SOUTHWEST ALONG ALEUTIAN ARC}

\section{WRANGELL VOLCANO}

CAVW \#1105-02

$62^{\circ} 00^{\prime} \mathrm{N} \quad 144^{\circ} 00^{\prime} \mathrm{W}$

$14,164 \mathrm{ft} \quad(4,317 \mathrm{~m})$

SUSPECT VOLCANIC ACTIVITY

Anomalous clouds over the volcano

Danny Rosenkrans, geologist for the Wrangell-St. Elias National Park and Preserve, contacted AVO on June 13, 2003 with photographs taken by a local resident on June 11, 2003 showing an unusual, towering, cloud over the summit area of Mt. Wrangell (fig. 4). Although the cloud might simply have been a common cumulus cloud fortuitously located at or near the summit, the lack of other cumulus clouds in the area over nearby Mts. Drum and Sanford suggest that instead, calm weather conditions permitted steam emissions from the known summit fumaroles to coalesce and form the plume-like cloud over Wrangell. AVO receives several reports per year from pilots and local residents who observe what they consider to be larger than normal steam clouds situated over the summit. 


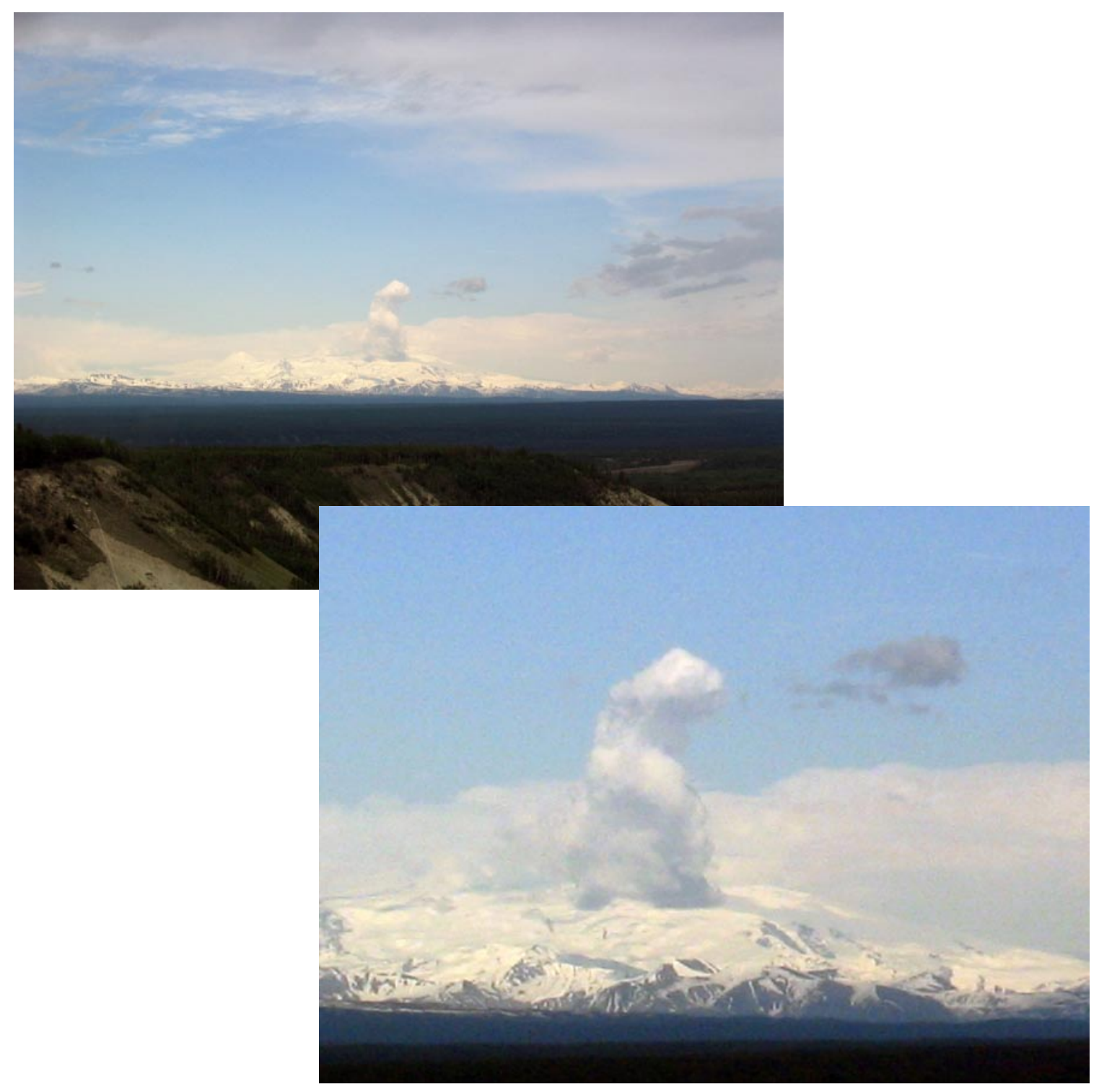

Figure 4. Views of anomalous, towering cloud over Mt. Wrangell volcano on June 11, 2003, 6:36 pm ADT. No unusual seismicity or satellite thermal anomalies were present at the time of this photo. Photograph by Copper Center resident Pinky Becker, used with permission.

On September 18, 2003 the Center Weather Service Unit (CWSU) called at 12:50 pm ADT with a Pilot Weather Report (PIREP) of a "2,000-to 2,300-foot-high steam plume" over Mt. Wrangell. The pilot reported no ash or sulfur smell. AVO scientists checked satellite imagery and seismograms and found nothing unusual.

Mt. Wrangell is a large, glacier-covered shield volcano in the Wrangell-St. Elias National Park and Preserve of eastern Alaska (Nye, 1991; Richter and others, 1995b). The summit caldera is ice-filled with three, small, geothermally active craters on the west rim, historically the source of intermittent steam venting. Resultant steam plumes can be quite vigorous and sometimes reach thousands of feet above terrain, occasionally entraining fine fragmental debris and producing discoloration of the summit area. This, in addition to wind redistribution of debris from the summit area, is often mistaken for eruptive activity (Neal and McGimsey, 1997; McGimsey 
and Wallace, 1999; McGimsey and others, 2004; Neal and others, 2005). Four real-time seismic monitoring stations are located on the volcano. Additionally, AVO relies on local observers, pilots, and satellite imagery to monitor activity at the volcano. Except for a vigorous steam and ash emission and possibly a small lava flow in 1902, no historical eruptions are known to have occurred at Wrangell volcano (Richter and others, 1995b).

\section{REDOUBT VOLCANO}

CAVW \#1103-03

$60^{\circ} 28^{\prime} \mathrm{N} \quad 152^{\circ} 45^{\prime} \mathrm{W}$

$10,197 \mathrm{ft} \quad(3,108 \mathrm{~m})$

\section{SUSPECT VOLCANIC ACTIVITY}

Anomalous weather cloud over the volcano

On November 25, 2003, an employee on the $18^{\text {th }}$ floor of the Conoco Phillips Building in downtown Anchorage reported a "white plume" over the general vicinity of Redoubt. Seismograms and spectrograms revealed nothing unusual other than typical wind noise. AVO staff called the CWSU of the FAA to request a PIREP from any planes flying over Redoubt and a short while later learned that there was "no steam but plenty of blowing snow". Photographs sent to AVO from the original observer at Conoco Phillips show an abrupt cloud edge forming over the general Redoubt area, and billowing downwind to the southeast. The clouds were a weather phenomenon that was mistaken for possible unrest at the volcano. AVO frequently receives similar reports about the Cook Inlet volcanoes during the spring and fall.

Redoubt Volcano is a glacier-clad, steep-sided stratocone, breached to the north, with an ice-filled summit crater and deeply incised valley glacier (Drift Glacier) that drains the crater (fig. 5). The volcano comprises pyroclastic deposits and lava flows constructed upon Mesozoic granitic rocks of the Alaska-Aleutian Range batholith (Till and others, 1993). The most recent eruption occurred December 14, 1989 through April 1990, and was characterized by 23 episodes of dome construction and destruction-some explosively, and some by gravitational collapse. The resulting pyroclastic flows mixed with ice and snow to produce voluminous lahars that threatened an oil storage and loading facility (fig. 6) located along the shore of Cook Inlet, $35 \mathrm{~km}$ (22 mi) downstream along the Drift River Miller and Chouet, 1994). 


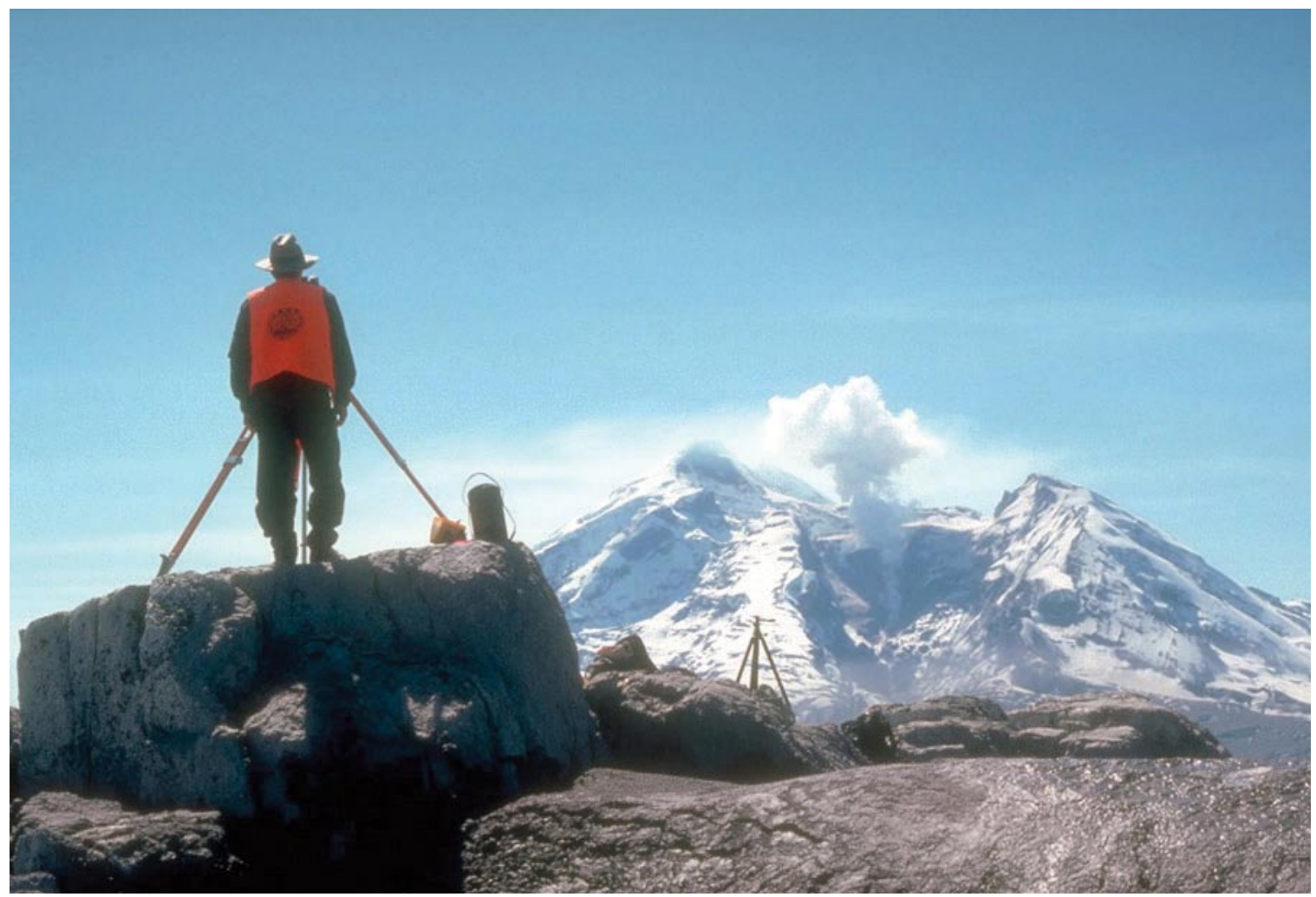

Figure 5. John Ewert (Cascade Volcano Observatory) using a laser surveying instrument to measure distances to reflective prisms or targets installed on the flanks of Redoubt Volcano in the distance during the 1989-1990 eruption. View is to the south. Photograph by G. McGimsey, May 4, 1990. 


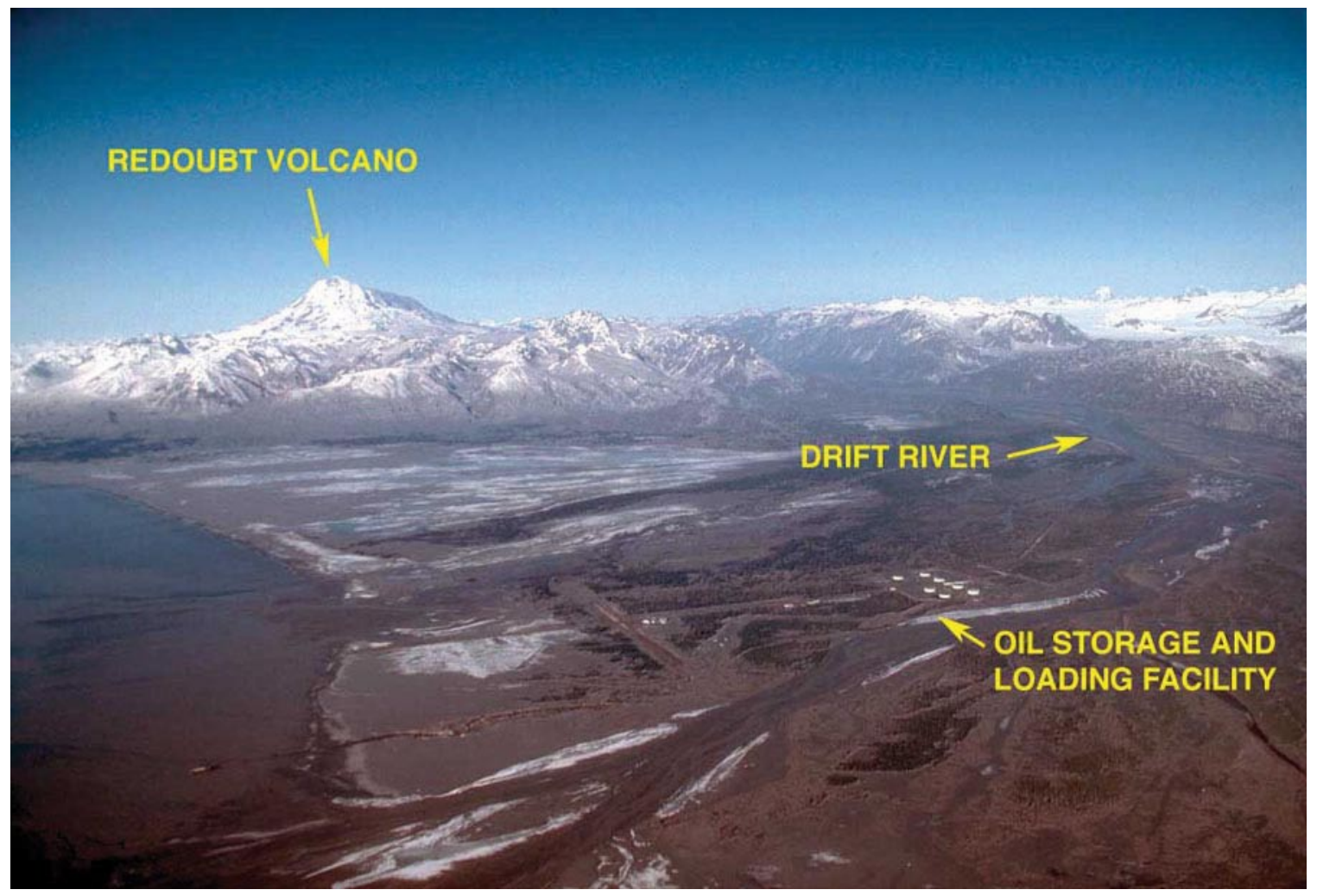

Figure 6. One of the principal facilities at risk during the 1989 to 1990 eruptions of Redoubt Volcano was the Drift River Oil Terminal located at the mouth of the Drift River, $35 \mathrm{~km}(22 \mathrm{mi})$ northeast of the volcano. This aerial view, looking southwest, shows the 1.9 million barrel capacity oil storage tanks. Redoubt Volcano is on the skyline at left. Photograph by G. McGimsey, April 13, 1990.

\begin{tabular}{l} 
ILIAMNA VOLCANO \\
CAVW \#1103-02 \\
$60^{\circ} 02^{\prime} \mathrm{N} \quad 153^{\circ} 04^{\prime} \mathrm{W}$ \\
$\begin{array}{ll}10,017 \mathrm{ft} & (3,053 \mathrm{~m}) \\
& \\
\text { SUSPECT VOLCANIC ACTIVITY } \\
\text { Avalanche recorded on seismic stations }\end{array}$ \\
\hline
\end{tabular}

On July 25, 2003, an avalanche of snow, ice, and rock occurred at Iliamna volcano, a site of frequent spring and summer avalanches (Neal and others, 1995; McGimsey and Wallace, 1999; McGimsey and others, 2004). The event lasted 4 minutes and was recorded on seismometers located as far away as $75 \mathrm{~km}$ (46 mi) on Augustine volcano. The avalanche presumably initiated from the same vicinity as in previous years, a steep portion of the east-southeast flank adjacent to an extensive fumarolic field and large zone of altered rock (fig. 7).

Iliamna is a dissected ice- and snow-covered stratocone that lies $225 \mathrm{~km}$ southwest of Anchorage in the Aleutian Range. A prominent fumarole field near the summit produces a nearly constant steam plume, which is often mistaken for eruptive activity. The fumaroles high on the south and east-northeast flanks occur where large scars reveal that most of the upper edifice consists of highly altered, unstable volcanic rock. The eastern scar has been the source of frequent 
non-volcanic gravitational collapses that produce mixed avalanches of ice, snow, rock, and mud that typically extend several kilometers down the flank; some are large enough to be visible from the Kenai Peninsula (Neal and others, 1995; McGimsey and Wallace, 1999). Although Iliamna has had no significant eruptive activity within the past 200 years (Waythomas and Miller, 1999), two strong, shallow, seismic swarms in 1996 indicate that the volcano remains restless. AVO maintains a 6-station seismic network on the volcano. 


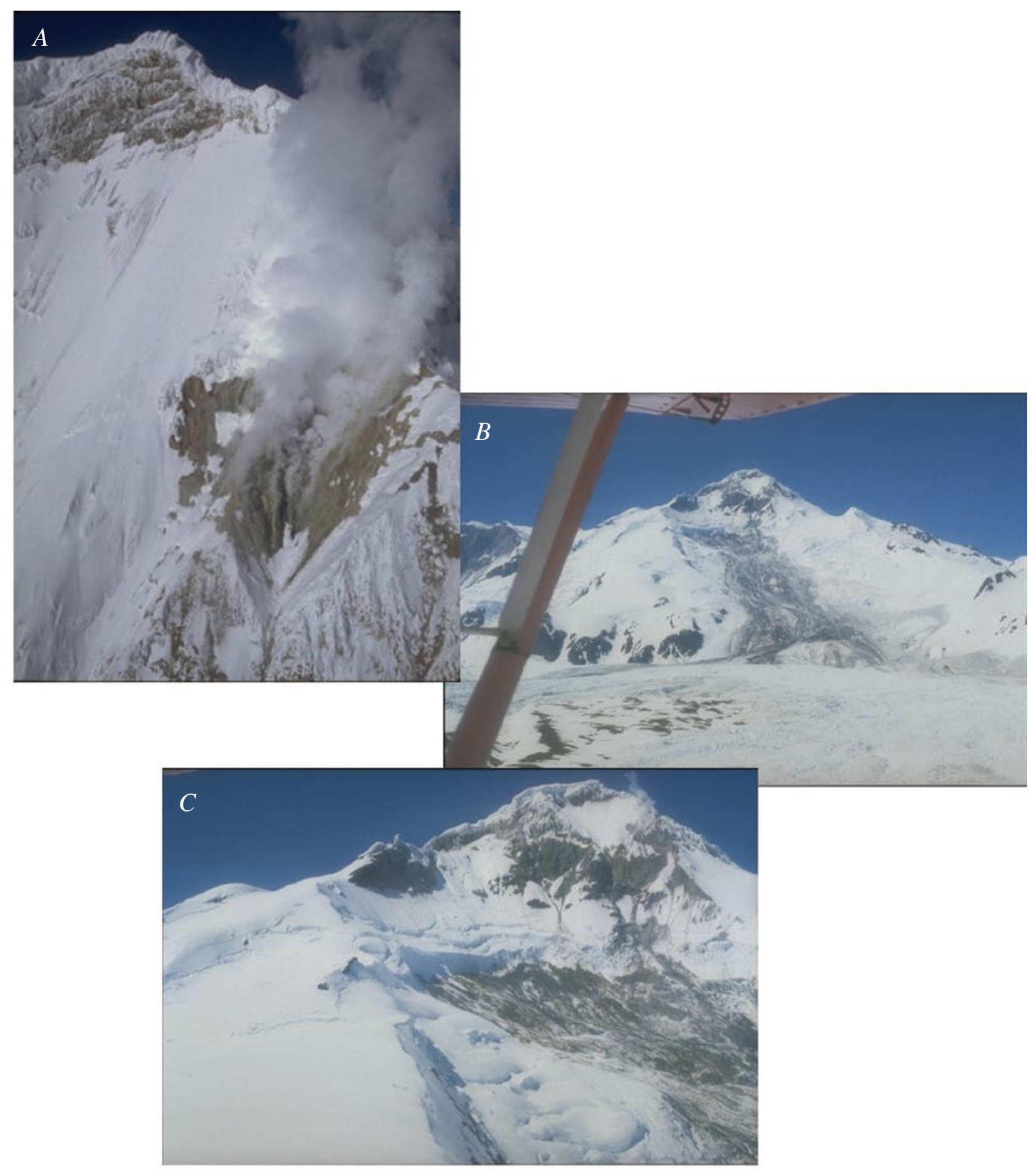

Figure 7. A: Permanent fumarole field on the upper east flank of Iliamna; photo by Guy Tytgat, 1994. B: Large snow, ice, and rock avalanche on the east flank of Iliamna that occurred July 1, 1994; the 2003 avalanche presumably occurred in this same location, as have other previous avalanches; photo by National Park Service. C: Close-up view of the headwall area of the 1994 avalanche and location relative to the permanent fumarole field; photo by National Park Service. Refer to Neal and others (1995) for details of the 1994 avalanche. 


\begin{tabular}{l}
\hline AUGUSTINE VOLCANO \\
CAVW \#1103-01 \\
$59^{\circ} 23^{\prime} \mathrm{N} \quad 153^{\circ} 26^{\prime} \mathrm{W}$ \\
$4,134 \mathrm{ft} \quad(1,260 \mathrm{~m})$ \\
SUSPECT VOLCANIC ACTIVITY \\
Report of increased steaming \\
\hline
\end{tabular}

AVO received a pilot report through Kenai Flight Service of increased steaming at Augustine volcano about mid-day on September 9, 2003. Concomitant to this report we received an inquiry about Augustine from the Homer Police Department. A check of the seismograms and spectrograms revealed nothing unusual.

Augustine volcano forms an island situated at the mouth of Cook Inlet (fig. 8). The stratocone has steep flanks comprising volcaniclastic debris and is topped with a large dome from the 1986 eruption as well as a cluster of dome remnants from previous historical eruptions. The nearest city is Homer, located approximately $100 \mathrm{~km}(62 \mathrm{mi})$ northeast across Cook Inlet. Augustine is the most frequently active of the Cook Inlet volcanoes with at least 7 historical eruptions (Miller and others, 1998).

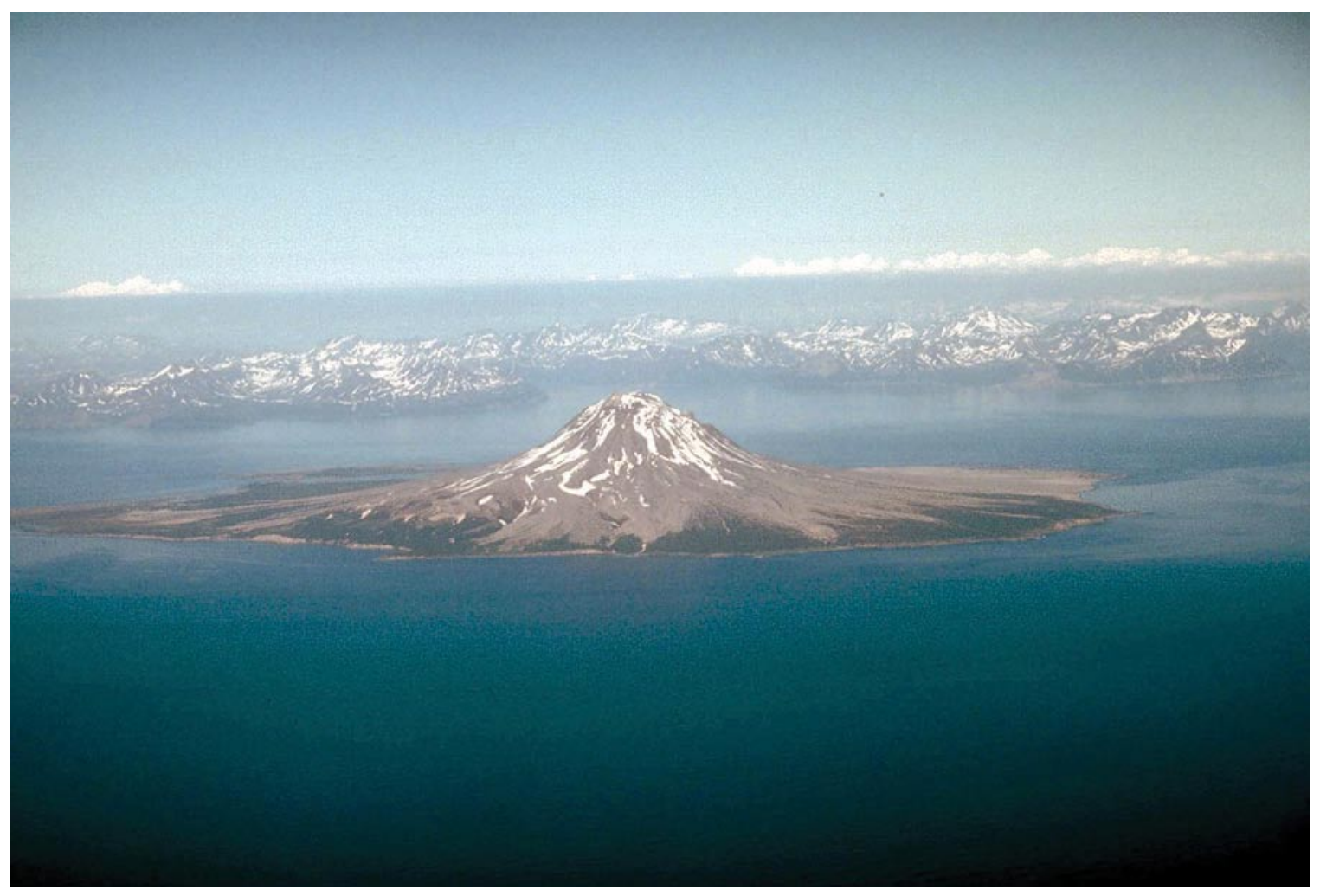

Figure 8. A symmetrical apron of pyroclastic debris extends from the summit of Augustine Volcano to sea level. The western shore of Cook Inlet can be seen in the distance. View is to the west. Photograph by C. Neal, June 4, 1990. 


\begin{tabular}{|l|}
\hline KATMAI GROUP (MT. MAGEIK) \\
CAVW \#1102-15 \\
$58^{\circ} 10^{\prime} \mathrm{N} \quad 155^{\circ} 21^{\prime} \mathrm{W}$ \\
$6,103 \mathrm{ft} \quad(1,860 \mathrm{~m})$ \\
\\
[Note: For the purposes of this report, the Katmai Group includes: Kukak, Snowy, Katmai, \\
Trident, Novarupta, Mageik, and Martin volcanoes (all closely situated within Katmai National \\
Park and Preserve on the Alaska Peninsula.)] \\
SUSPECT VOLCANIC ACTIVITY \\
Reports of steaming; cloud of re-suspended ash mistaken for eruption cloud \\
\hline
\end{tabular}

AVO received a PIREP of steaming in the Katmai area - specifically at coordinates $58^{\circ} 16^{\prime}, 154^{\circ} 50^{\prime}$ - that was rising to an estimated 17,000 ft. ASL on February 15, 2003. The AAWU called to consult as to whether or not to issue a Significant Meteorological Information Statement (SIGMET). A check of the webicorders and spectrograms revealed no unusual seismicity at any of the Katmai Group volcanoes and no advisory was forthcoming. Based on the coordinates reported and the past reports of steaming, the most likely source was Mageik (fig. 9). Nearby Martin also typically issues a vigorous steam plume.

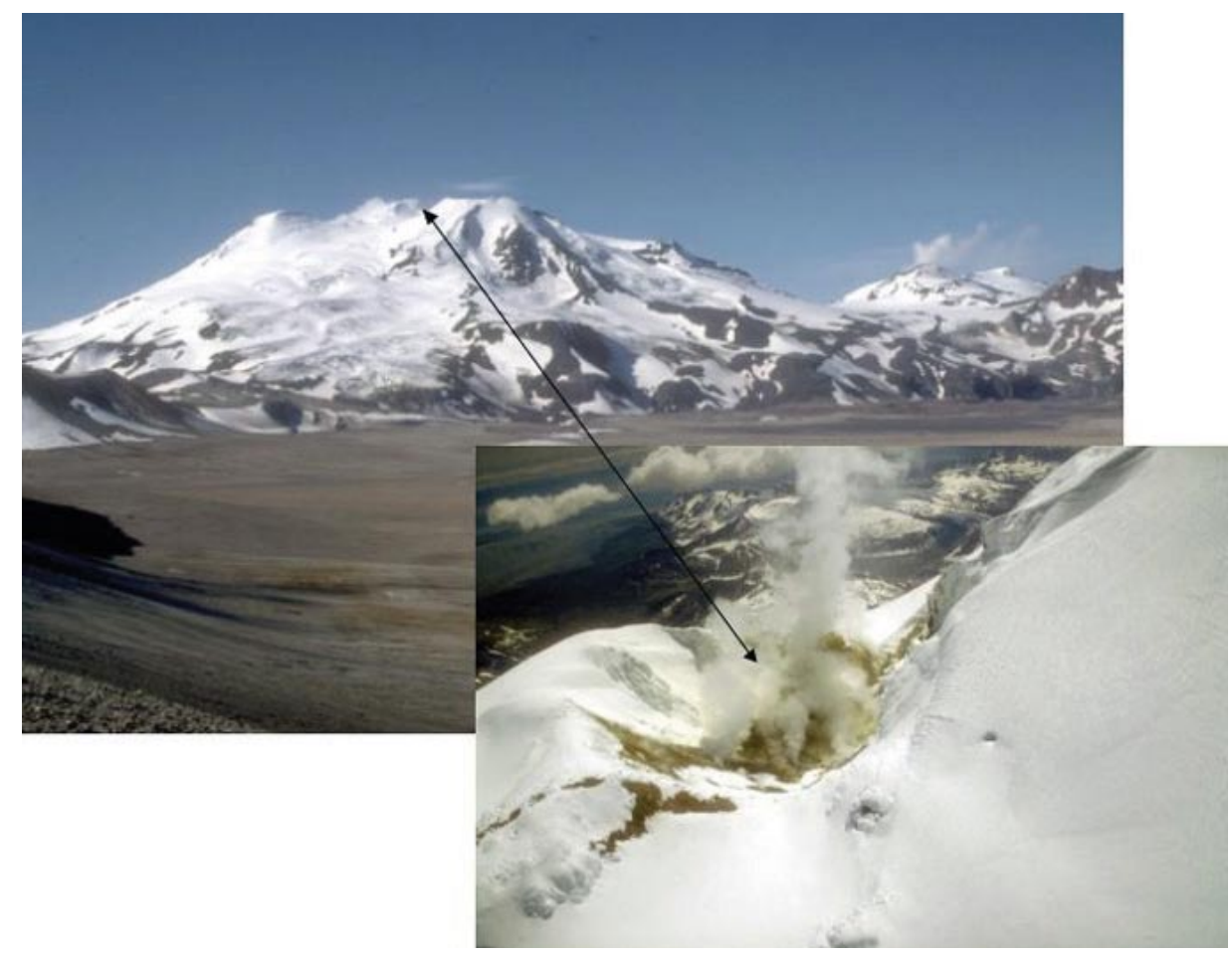

Figure 9. Mount Mageik (left skyline) and Mount Martin (right skyline) volcanoes as viewed to the southwest from across the Valley of Ten Thousand Smokes (VTTS), Katmai National Park and Preserve,

Alaska. Both are emitting steam plumes from their summits. Photograph by G. McGimsey, July 15, 1990. Inset photograph shows an acidic, hot $\left(70^{\circ} \mathrm{C}\left[158^{\circ} \mathrm{F}\right]\right)$ crater lake nestled within a summit depression of Mount Mageik volcano where persistent, vigorous fumaroles are present. No historical magmatic eruptions from Mounts Mageik or Martin have been confirmed (Fierstein and Hildreth, 2000). Photograph by C. Neal, June 4, 1990. 
An observer in the town of Naknek (about $110 \mathrm{~km}$ [70 mi.] from Mageik) called on April 8, 2003 to report two 'significant' steam plumes coming from 2 mountains in the VTTS the previous evening. Having lived in the area for 40 years, he stated that he had never seen anything as large as these plumes, although he estimated the plumes to be about 3,000 ft above the mountaintops. AVO staff checked the webicorders and spectrograms of the greater Katmai network and found nothing out of the ordinary. The observer was advised that he was likely seeing vigorous steam plumes emanating from Martin and Mageik, a common occurrence in the Katmai area.

On September 21, 2003, strong northwesterly winds sweeping through the VTTS in Katmai National Park entrained ash from the 1912 deposits to form a substantial cloud that was carried over Shelikof Strait, Kodiak Island, and the Gulf of Alaska (fig. 10). Particle fallout on Kodiak Island was mistaken as material from an eruption cloud.

Upon receiving the reports from Kodiak, AVO scientists analyzed satellite imagery and area seismic data and determined that the phenomenon was non-eruptive in origin. The National Weather Service (NWS) was contacted to confirm the existence of strong winds in the area, and then AVO issued an Information Release at 2:30 pm ADT (22:30 UTC) explaining the cloud's source and cautioning that despite the non-eruptive origin, the cloud-composed of remobilized volcanic ash — nonetheless posed a potential hazard to aircraft.

The VTTS formed during a 60-hour eruption on June 6-8, 1912 during the cataclysmic eruption from the Novarupta vent (fig.11). The caldera-producing eruption was the largest on earth in the $20^{\text {th }}$ century, resulting in $11 \pm 3 \mathrm{~km}^{3}\left(2.6 \mathrm{mi}^{3}\right)$ ignimbrite that filled a pre-eruption glacial valley to a maximum depth of $200 \mathrm{~m}\left(660 \mathrm{ft}\right.$.), and $17 \mathrm{~km}^{3}\left(4 \mathrm{mi}^{3}\right)$ of fall deposits, collectively representing $13 \mathrm{~km}^{3}\left(3 \mathrm{mi}^{3}\right)$ of magma volume (Hildreth and others, 2003)(fig. 12). 


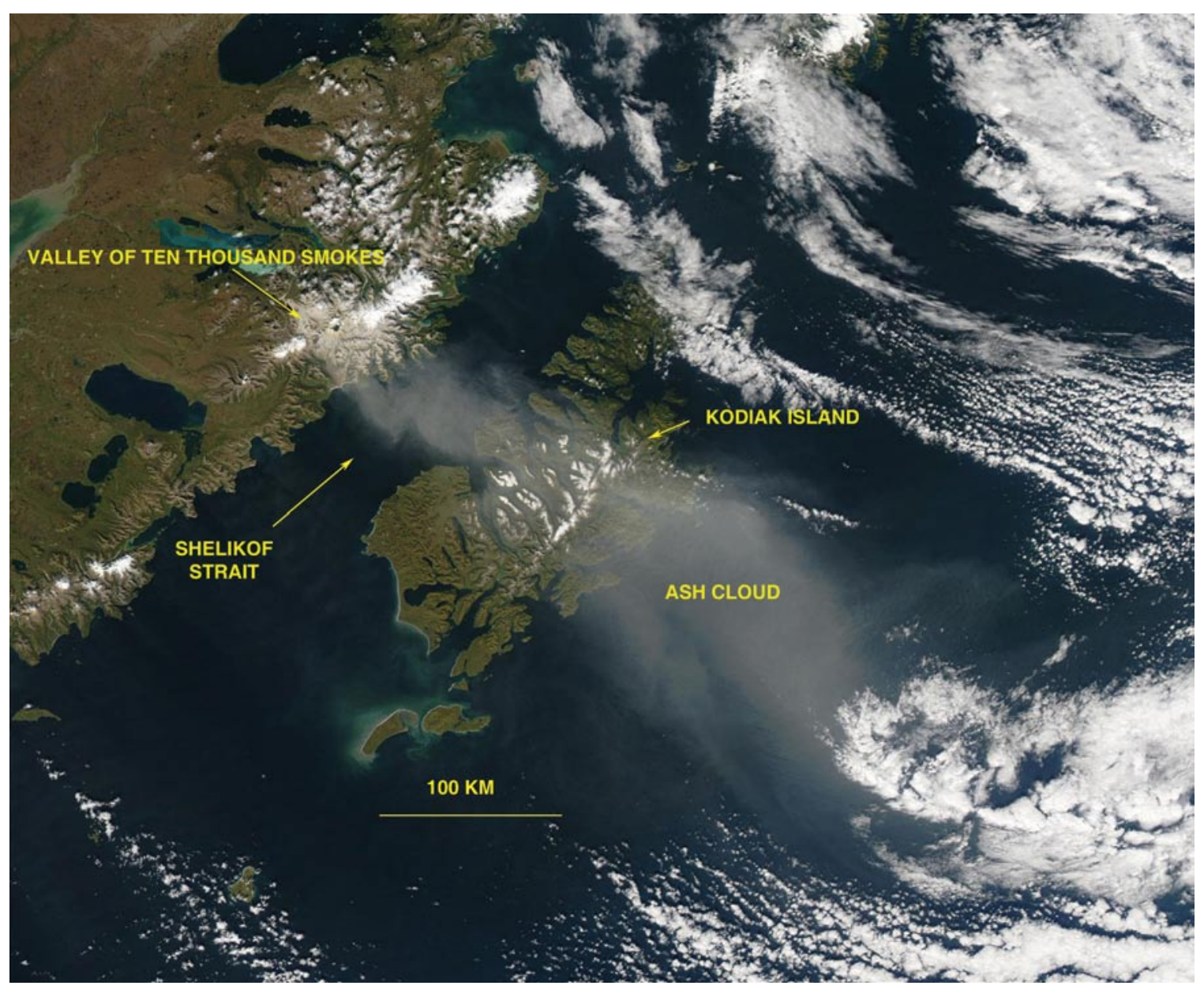

Figure 10. Moderate Resolution Imaging Spectroradiometer (MODIS) satellite image acquired on September 3, 2003 showing the non-eruptive ash plume formed by strong northwesterly winds sweeping through the Valley of Ten Thousand Smokes (VTTS) in Katmai National Park and Preserve. The re-suspended ash extends from the VTTS across Shelikof Strait and Kodiak Island, and into the Gulf of Alaska. Refer to Figure 1 for area location. North is towards the top. 


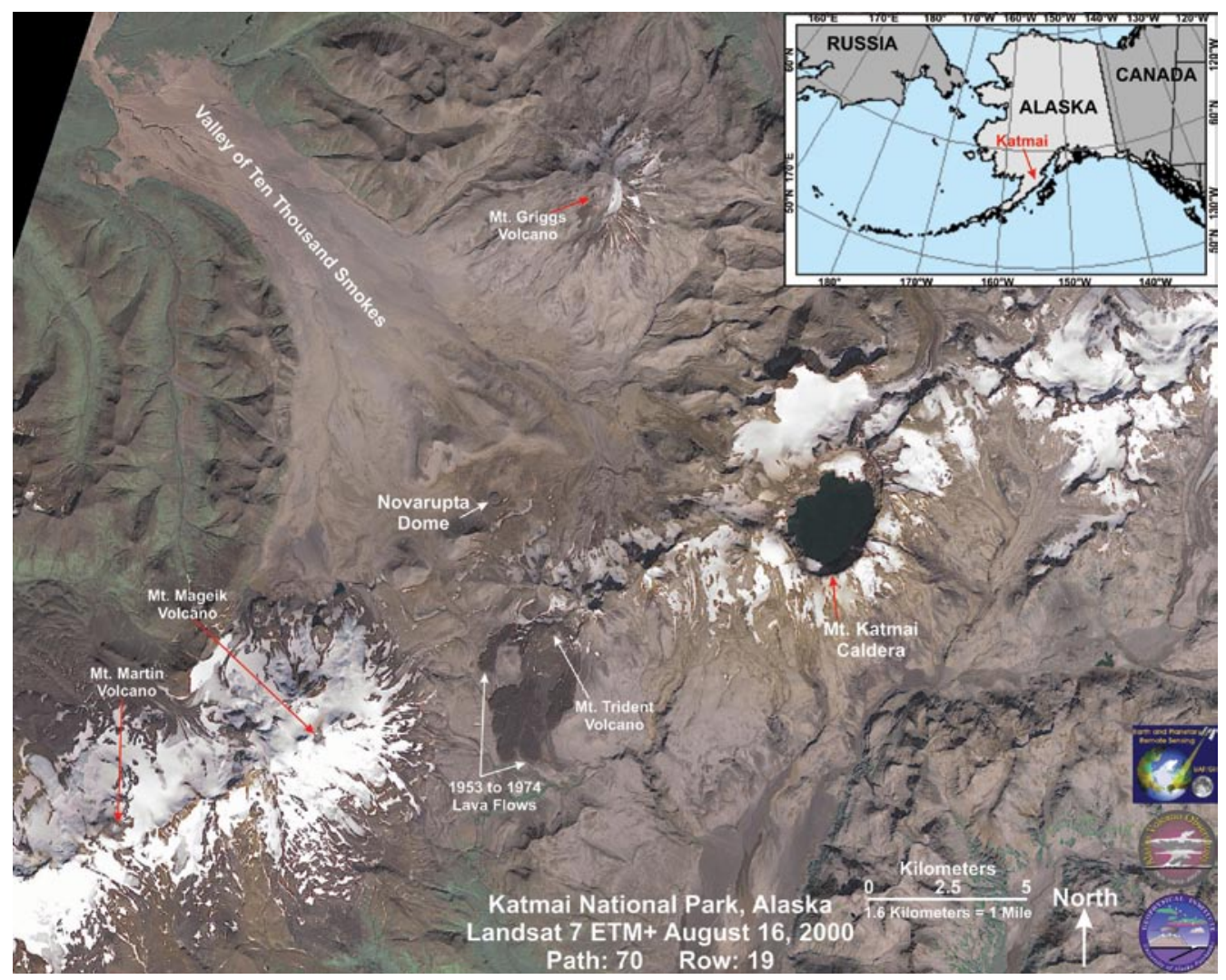

Figure 11. Landsat 7 satellite image acquired on August 16, 2000 showing the VTTS, Novarupta dome (vent), and Katmai Caldera. Image courtesy of Steve Smith, AVO.

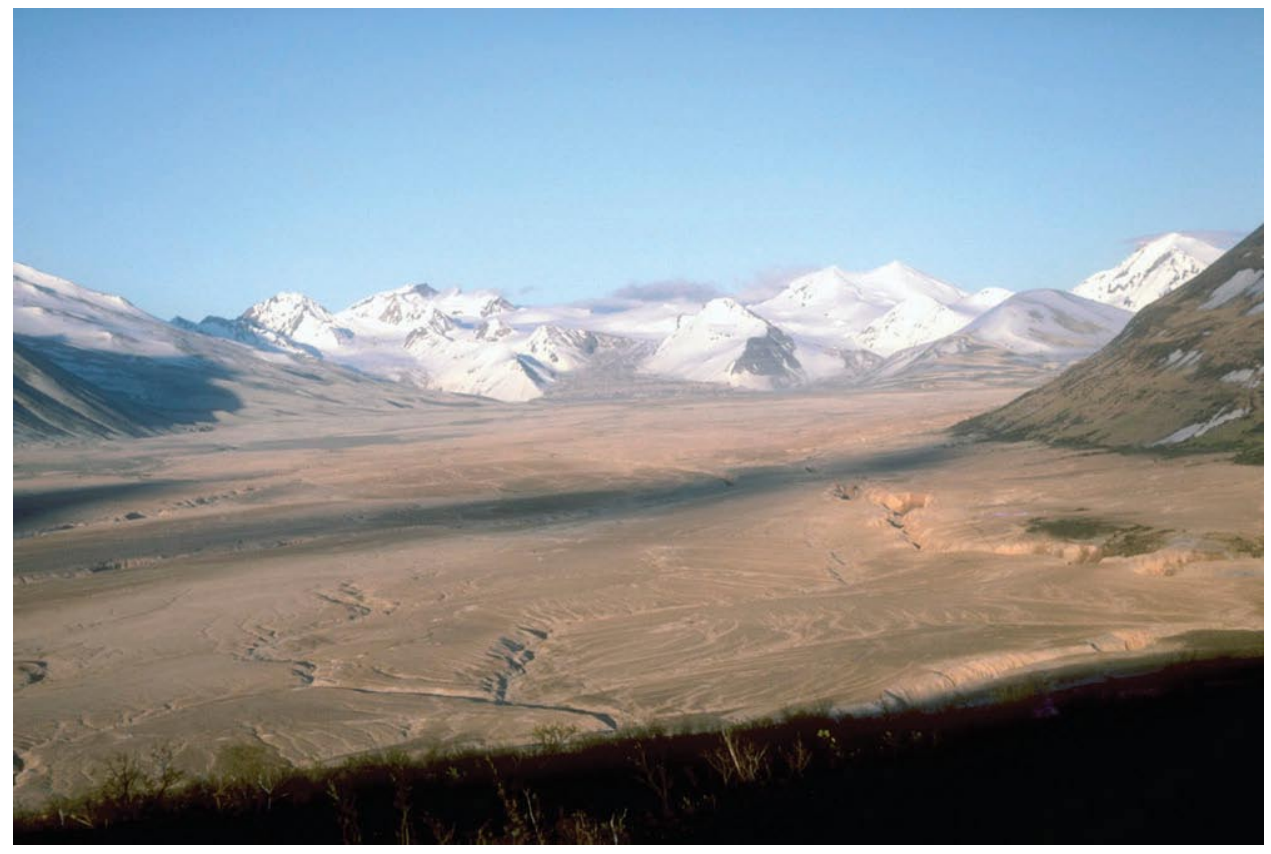

Figure 12. View southeast up the VTTS from the Overlook Cabin in Katmai National Park and Preserve, Alaska. The valley is filled with up to $200 \mathrm{~m}$ (660 ft) of ash-flow deposits from the 1912 eruption of Novarupta volcano. The rim of Katmai Caldera is on the skyline at left. Strong winds blowing up the valley sweep up loose ash to form large dust plumes resembling eruption clouds. Photograph by G. McGimsey, June 10, 1991. 


\section{VENIAMINOF VOLCANO}

CAVW \#1102-07

$56^{\circ} 10^{\prime} \mathrm{N} \quad 159^{\circ} 23^{\prime} \mathrm{W}$

$8,226 \mathrm{ft} \quad(2,507 \mathrm{~m})$ [high point on caldera rim]

\section{LOW-LEVEL, PHREATIC (?) ERUPTIONS}

Intermittent, low-level, dilute ash and steam plumes from the historically active, intracaldera cone; continued activity that started in September, 2002; fallout limited to within ice-filled caldera

Following several days of increasingly frequent and energetic seismic events recorded on multiple stations of the Veniaminof network (installed in summer 2001), AVO increased the Level of Concern Color Code to YELLOW on September 11, 2002 (Neal and others, 2005). By September 24, 2002, 'puffs' of faint gray clouds were observed originating from the intracaldera cone, which has been the source of all known historical eruptions at Veniaminof (fig. 13; Miller and others, 1998). Intermittent observations of similar activity along with 'rumbling' were reported by residents of Perryville (located $35 \mathrm{~km}$ or $22 \mathrm{mi}$ south of the volcano) through early October, although no clear correlative signals were apparent on seismograms from the area network. A localized gray ash deposit in the caldera was noted on MODIS satellite imagery taken on October 2, 2002, but no thermal anomaly was detected (fig. 14). Seismicity and reports of steaming from the intracaldera cone gradually declined through the remainder of the fall, and the color code was downgraded to GREEN on November 18, 2002.

Seismicity began to gradually increase again in mid-December, 2002, and Perryville residents reported seeing the intracaldera cone "covered with ash and...darkened snow all around the cone". On January 3, 2003, AVO belatedly received a report from the caretaker of a lodge located northwest of the volcano describing his observations from about mid-December, 2002, during clear weather, of distinct puffs of steam coming from the intracaldera cone. AVO upgraded the Level of Concern Color Code to YELLOW on Monday, January 6, 2003. Several weeks of poor weather conditions followed before clear views revealed that intermittent episodes of steam and diffuse ash emissions from the active cone continued (fig. 15). AVO seismologists detected the onset of small, volcano-tectonic earthquakes on Veniaminof seismic stations beginning on the morning of January 29, 2003 and a commensurate decline in amplitudes and numbers of low-frequency events (S. Moran, written communication). Elevated seismicity continued, and on March 11, a 4-hour period of continuous seismic tremor was observed followed by 17 hours of discrete seismic events and 3-4-minute-long tremor bursts. This culminated with another 4-hour period of continuous tremor on March 12, which was followed by a distinct decline in seismicity over the next several days. The last report of emissions from the active cone was from Mark Battaion in Perryville on March 23, 2003 (fig. 16).

With seismicity having dropped to near background levels, and no further reports of steaming from the active cone, AVO downgraded the color code to GREEN on April 18, 2003. The volcano remained quiet throughout the remainder of 2003 but activity resumed in February 2004.

Veniaminof is a huge ( $35 \mathrm{~km}$ wide [22 mi]) andesitic stratovolcano with an ice-filled, 10$\mathrm{km}$ diameter (6 mi) summit caldera located on the Alaska Peninsula, $775 \mathrm{~km}(480 \mathrm{mi})$ southwest 
of Anchorage and $35 \mathrm{~km}$ (22 mi) north of Perryville (fig. 1). Veniaminof has erupted at least 12 times in the past 200 years (Miller and others, 1998). The most recent eruption occurred in 199395 from the prominent intracaldera cinder and spatter cone (Neal and others, 1995; McGimsey and Neal, 1996). The eruption was characterized by intermittent, low-level emissions of steam and ash, and the production of a small lava flow that melted a pit in the caldera ice at the base of the erupting cone. Previous historical eruptions have produced ash plumes that reached $6,000 \mathrm{~m}$ $(20,000 \mathrm{ft})$ above sea level and ash fallout that affected areas within about $40 \mathrm{~km}(25 \mathrm{mi})$ of the volcano.

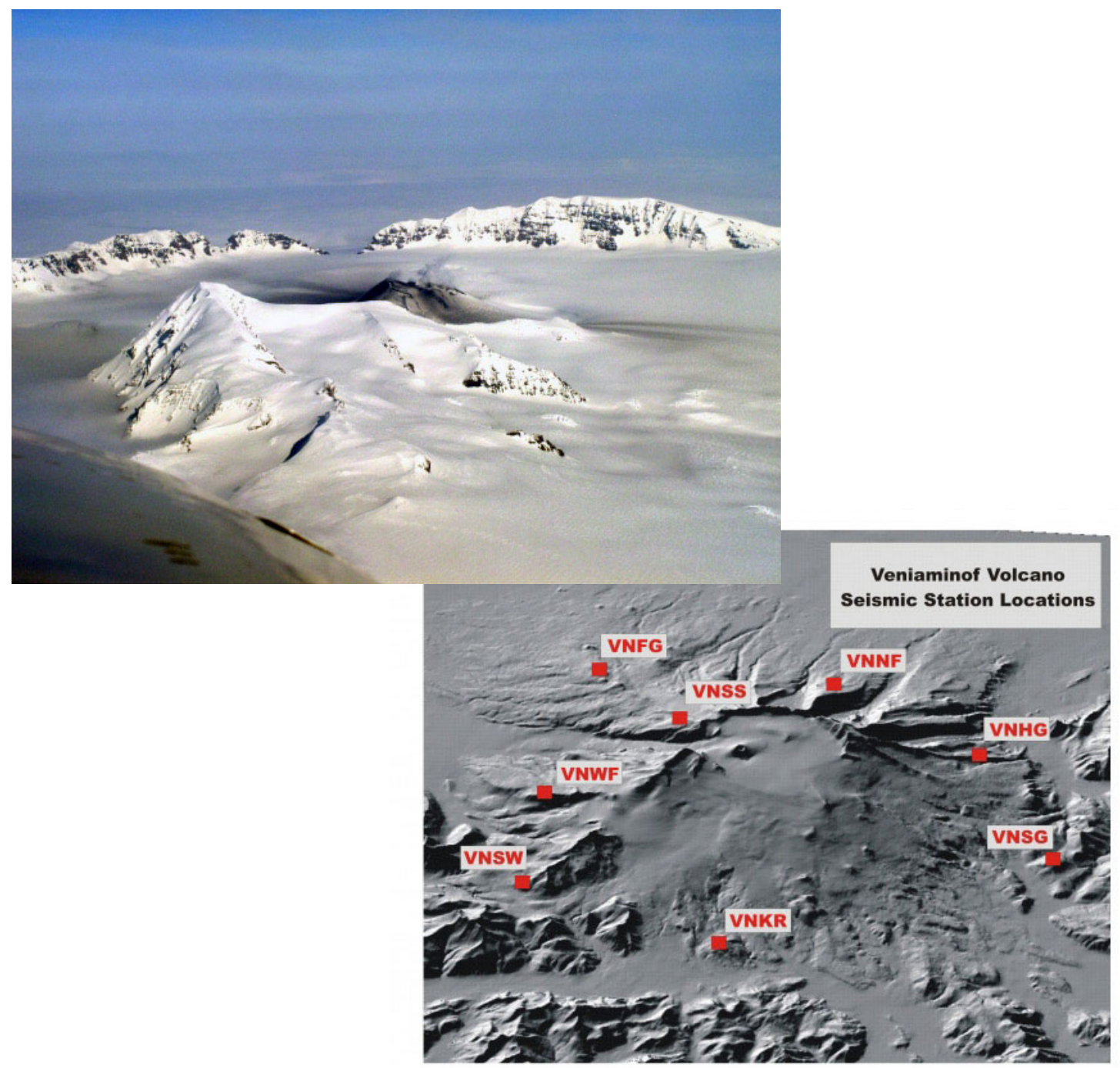

Figure 13. A: View to the northeast of Veniaminof caldera and the historically active intracaldera cone; photo by Nathan Fratzke, 2004. Used with permission. B: Oblique shaded-relief digital elevation model (DEM) of Veniaminof caldera showing locations of seismic stations. For scale, the caldera is about $10 \mathrm{~km}$ $(6 \mathrm{mi})$ in diameter. 


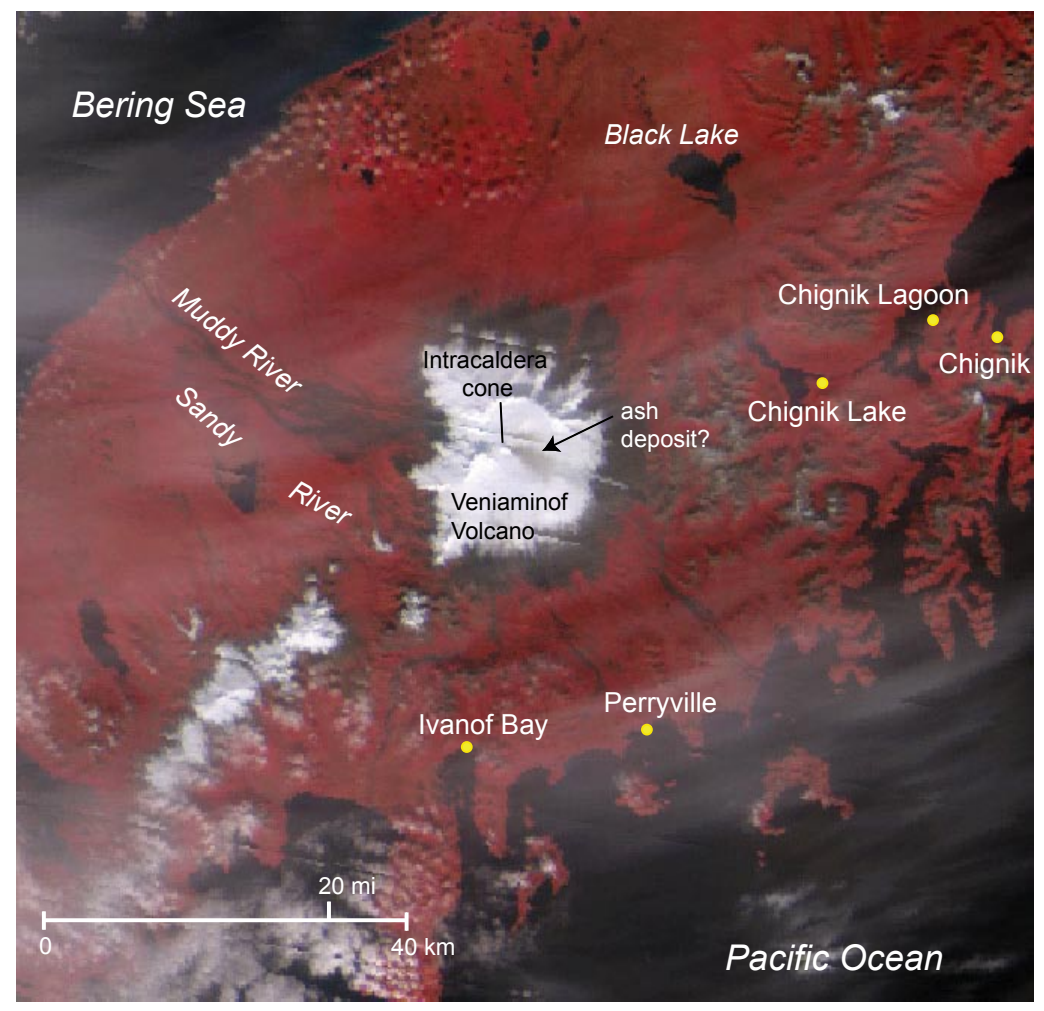

Figure 14. MODIS image of Veniaminof caldera taken on October 2, 2002. Thick arrow points to a light deposit of gray ash on the caldera floor. Note location of the village of Perryville referred to in text.

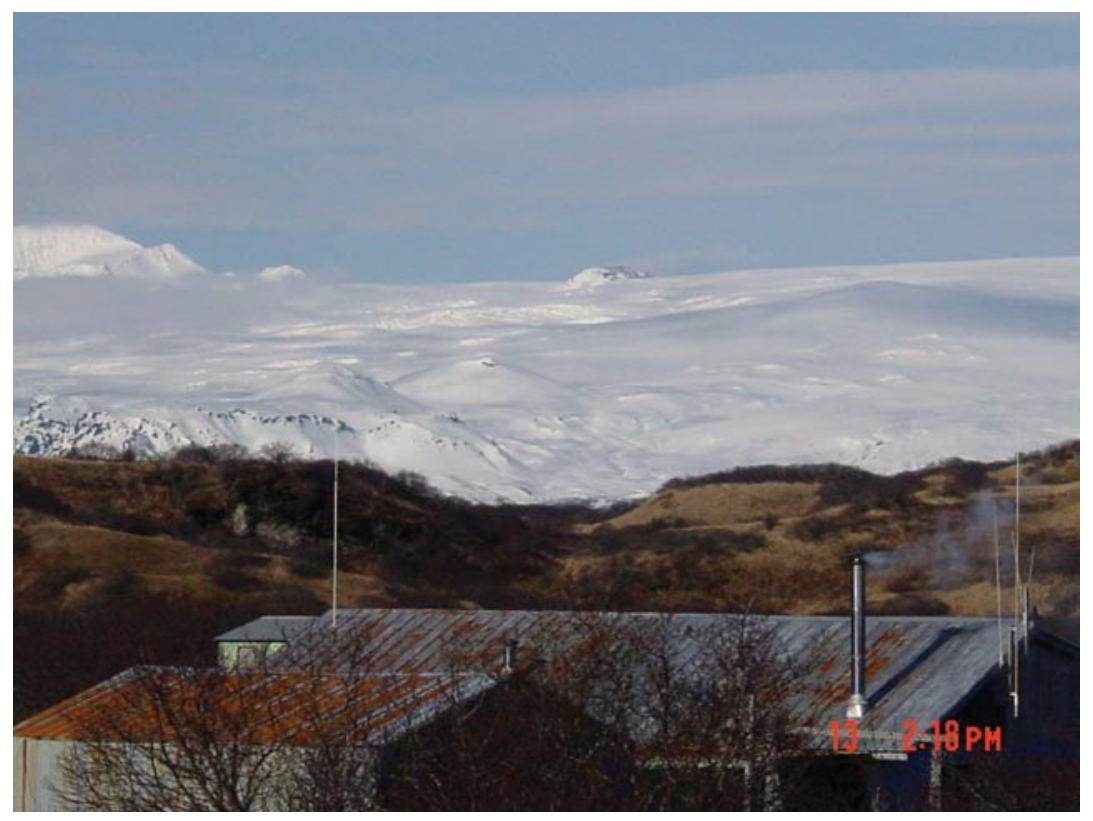

Figure 15. View northwestward from the village of Perryville over the southeastern rim of Veniaminof caldera. The active intracaldera cone-emitting a weak steam plume-is visible in center just above the skyline. 


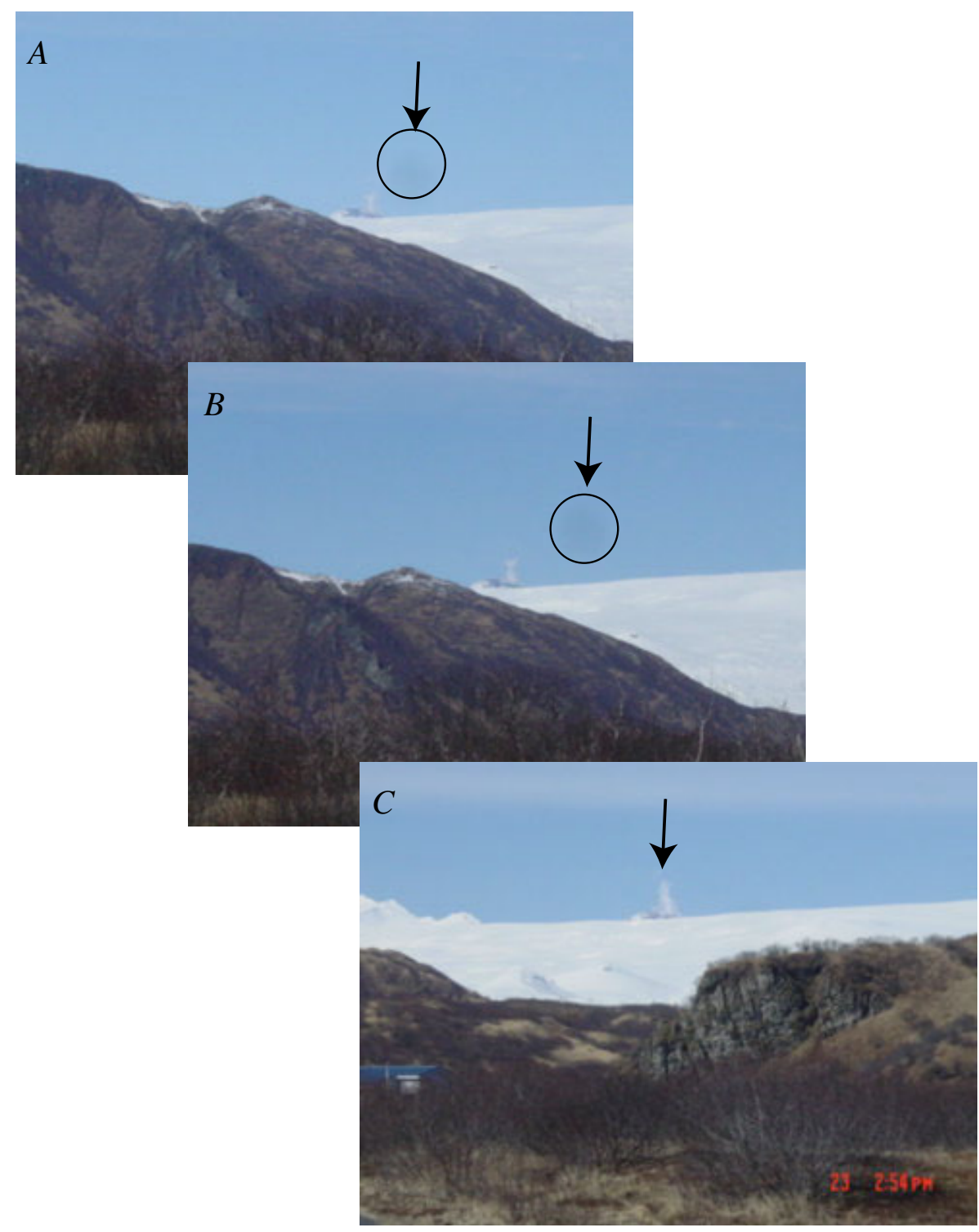

Figure 16. A-B: Arrows point to a thin ash plume ['puff'] rising from Veniaminof's active cone. C: A steam burst from the intracaldera cone. Photographs by Mark Battaion, March 23, 2003. Used with permission.

\section{PAVLOF VOLCANO}

CAVW \#1102-03

$55^{\circ} 25^{\prime} \mathrm{N} \quad 161^{\circ} 53^{\prime} \mathrm{W}$

$8,264 \mathrm{ft} \quad(2,519 \mathrm{~m})$

SUSPECT VOLCANIC ACTIVITY

Eruption report

A barge operator reported seeing Pavlof volcano erupting about 10 AM AST on March 16,2003 . A check of spectrograms revealed no activity. CWSU staff was informed of the report; 
they had already reviewed the latest satellite imagery and saw no ash signature (the area was cloudy with a ceiling of around 3,000 ft.). AVO remote sensing specialists corroborated that there was no indication of activity.

Strong fumaroles on the flank, and in the crater, of nearby Mt. Hague vent of Emmons Lake Caldera occasionally produce steam clouds that from certain vantage points appear to originate at Pavlof. A similar occurrence was documented in 2001 (McGimsey and others, 2005) and in 2002 (Neal and others, 2005).

Pavlof, the most frequently active of Alaska's volcanoes (40 eruptions since 1790), is a snow- and ice-covered, conical stratovolcano; a high ridge extends to the southwest and joins the rim of Emmons Lake Caldera (fig. 18). Located $60 \mathrm{~km} \mathrm{(37} \mathrm{mi)} \mathrm{northeast} \mathrm{of} \mathrm{Cold} \mathrm{Bay} \mathrm{and} 75 \mathrm{~km}$ (47 mi) southwest of Nelson Lagoon, near the southwest end of the Alaska Peninsula (fig. 1), the volcano lies above the zone of fastest and most orthogonal convergence along the Aleutian Arc. Pavlof's last eruption began in September 1996, and continued into January 1997. The strombolian eruption was characterized by lava fountains, lava flows, lahars, and ash plumes to more than $35,000 \mathrm{ft}(\sim 10.6 \mathrm{~km})$ ASL causing temporary disruption of air traffic (Neal and McGimsey, 1997). AVO maintains a six-station seismic network installed in 1996 and continues to closely monitor the seismicity and satellite imagery for impending signs of unrest.

\section{MT. HAGUE VENT OF EMMONS LAKE CALDERA \\ CAVW \#1102-02 \\ $55^{\circ} 22^{\prime} \mathrm{N} \quad 161^{\circ} 59^{\prime} \mathrm{W}$ \\ $4,400 \mathrm{ft} \quad(1,341 \mathrm{~m})$ \\ SUSPECT VOLCANIC ACTIVITY \\ Crater lake drains; refills}

On July 7, 2003, AVO scientists conducting seismic network maintenance near Mt. Hague on the rim of Emmons Lake Caldera noticed that the crater lake typically present was almost completely gone and all that remained was a few isolated pools surrounded by several vigorously venting fumaroles, and yellow sulfur deposits in the center of the crater (fig. 17). Mud cracks suggested that the lake had drained or evaporated rather recently. A photograph taken a week later, August 16, 2003, shows a full lake (fig. 17). Photographs taken of the crater lake on August 16, 2002 also show the lake filled with water. 

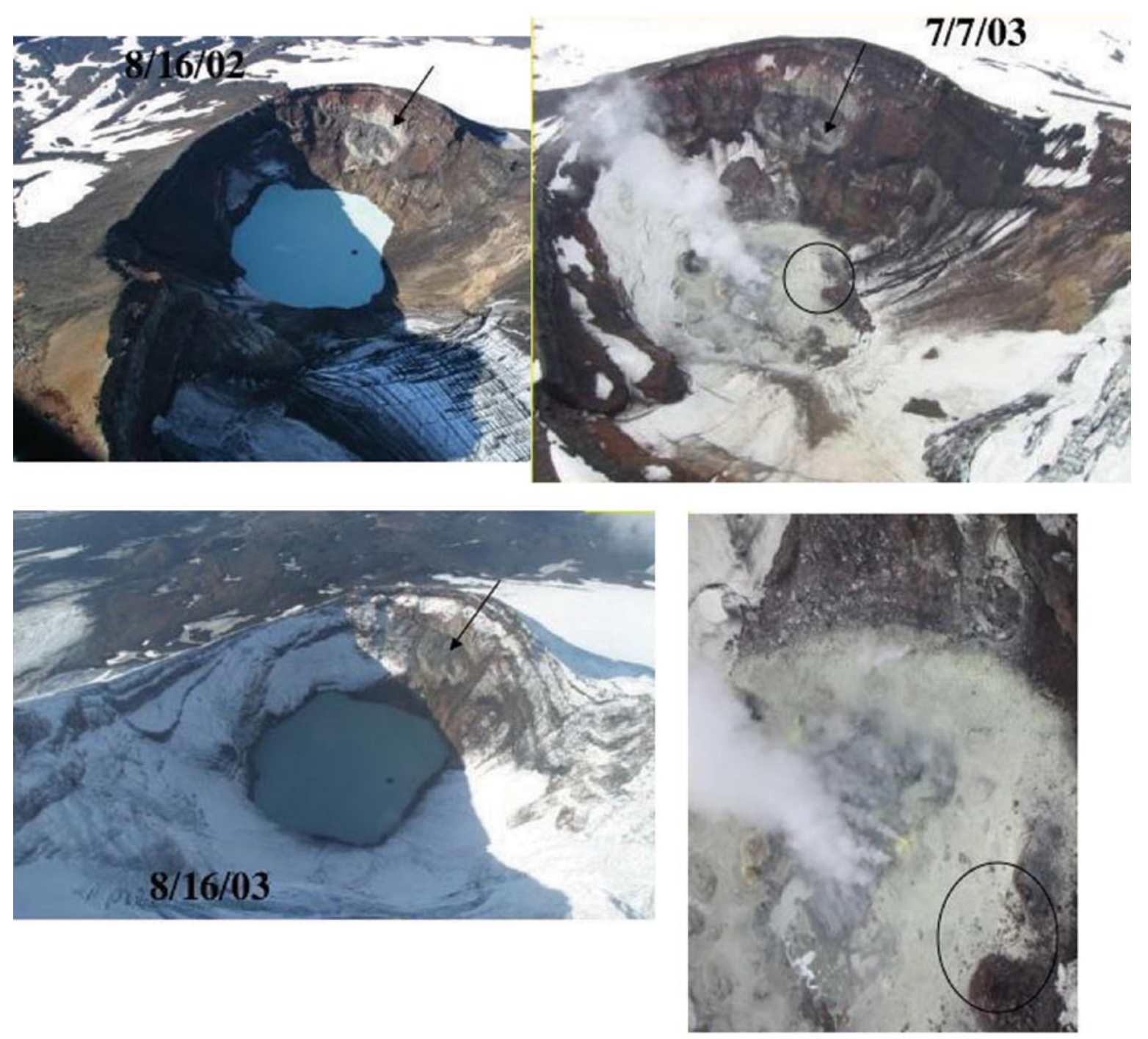

Figure 17. Photographic series showing the crater lake at Mt. Hague. The lake is full in 2002, empty in July 2003, and full again by August 2003. The arrows reference the same feature in the crater wall; the circles indicate a reference point on the crater floor in the July 2003 photographs. The 2002 and August 2003 photographs are by C. Waythomas, USGS; the July 2003 photographs are by G. Tytgat, UAFGI.

The Hague crater lake apparently has a history of draining and refilling. Sporadic checks of the crater since 1973 have found it empty about as often as full (T. Miller, written communication, 2003). The most recent observations [2003] verify that the lake is capable of reforming within days or weeks.

Hague is a stratocone within the Pleistocene Emmons Lake Caldera (fig. 18). Although no historic eruptions are attributed to Hague, the summit crater contains strong, active fumaroles and lava flows on its flanks appear very fresh (Kennedy and Waldron, 1955). Additionally, a fumarolic area on the east flank of Hague has been continuously active. Steam plumes from Hague fumaroles are occasionally mistaken for activity at nearby Pavlof volcano, Alaska's most frequently active volcano (Miller and others, 1998). 


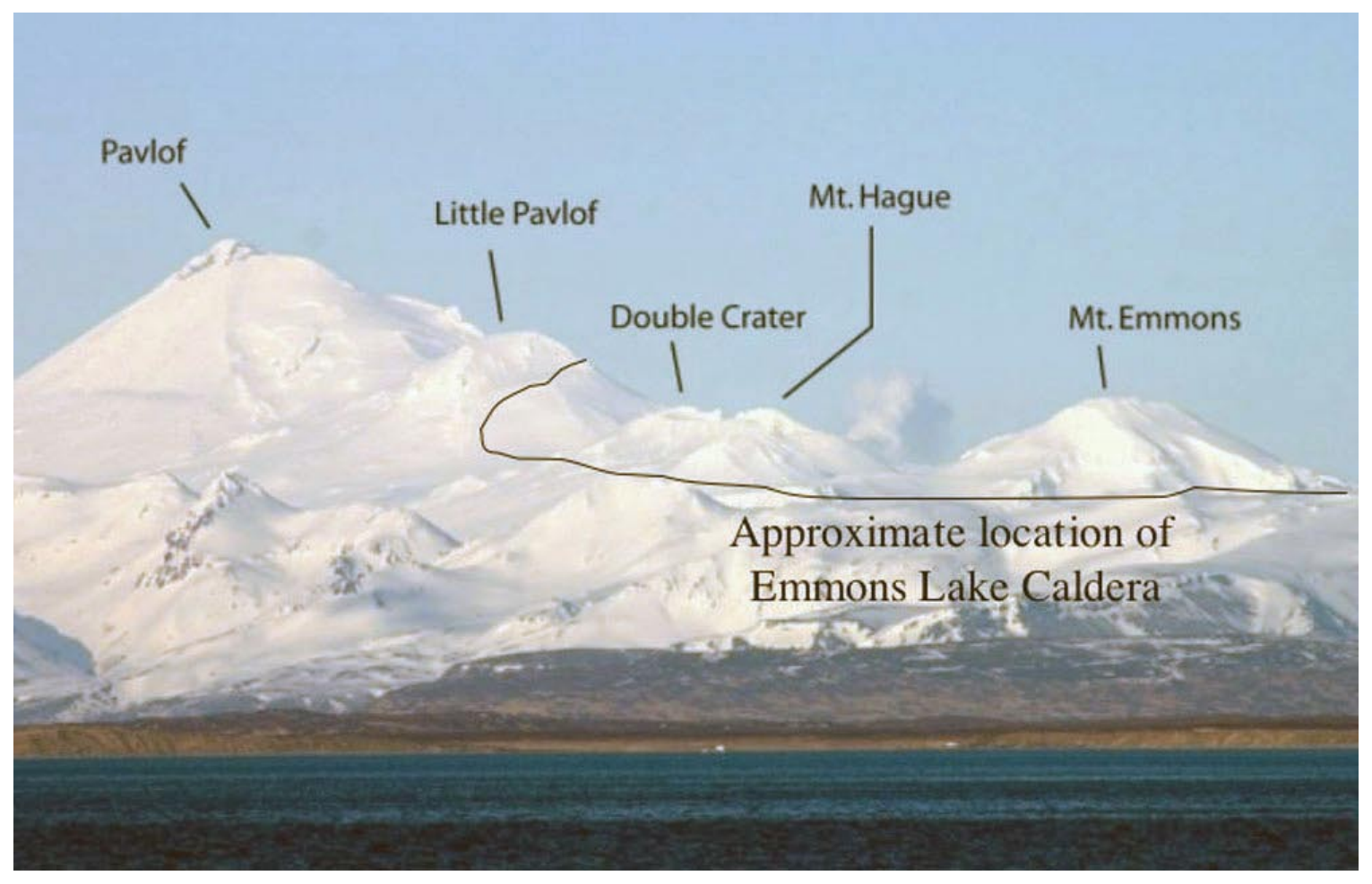

Figure 18. View of Pavlof, Little Pavlof, Double Crater, Mt. Hague, and Mt. Emmons, looking south. Steam appears to be originating from the vicinity of Mt. Hague-either from Hague's crater lake (fig. 17), or its east flank fumarole field. Photograph by Nathan Foster, April 16, 2005. Used with permission.

\section{SHISHALDIN VOLCANO \\ CAVW \#1101-36 \\ $54^{\circ} 45^{\prime} \mathrm{N} \quad 163^{\circ} 58^{\prime} \mathrm{W}$ \\ $9,373 \mathrm{ft} \quad(2,857 \mathrm{~m})$ \\ SUSPECT VOLCANIC ACTIVITY \\ Steam plumes}

The AAWU called AVO on January 31, 2003 to relay an 11:00 AST (2000 UTC) PIREP from the Cold Bay Flight Service Station of a steam plume from Shishaldin with tops to 16,000 $\mathrm{ft}(4,875 \mathrm{~m}) \mathrm{ASL}$ and moving to the north. The pilot reported no sulfur smell. AVO staff checked the seismic data for Shishaldin and found no change at the time of the PIREP.

Another PIREP was reported to AVO on the morning of September 12, 2003 concerning a steam plume observed rising $500 \mathrm{ft}(\sim 150 \mathrm{~m})$ above the top of Shishaldin. The time of the report was 11:07 ADT (19:07 UTC) and neither satellite nor seismic data indicated anything unusual. This information was subsequently reported back to AAWU.

Shishaldin Volcano, located about 1,100 km ( 680 mi) southwest of Anchorage near the center of Unimak Island, is a spectacular symmetric stratocone that forms the highest peak in the 
Aleutian Islands (fig. 19). It is one of the most active volcanoes in the Aleutian arc with at least 27 eruptions since 1775 (Miller and others, 1998). The last eruptive period occurred in 1999 and consisted of Strombolian fountaining that culminated in a subplinian eruption, with an ash cloud rising to 45,000 ft. ASL ( 13,700 m) (Nye and others, 2002; McGimsey and others, 2004). Strombolian eruptions and ash and steam emissions characterize most of the documented eruptive activity at Shishaldin Volcano. Nearly constant fumarolic activity within the summit crater produces a steam plume that can occasionally be quite vigorous and typically results in numerous false eruption reports. The nearest community is False Pass, $32 \mathrm{~km}$ (20 mi) east-northeast of the volcano.

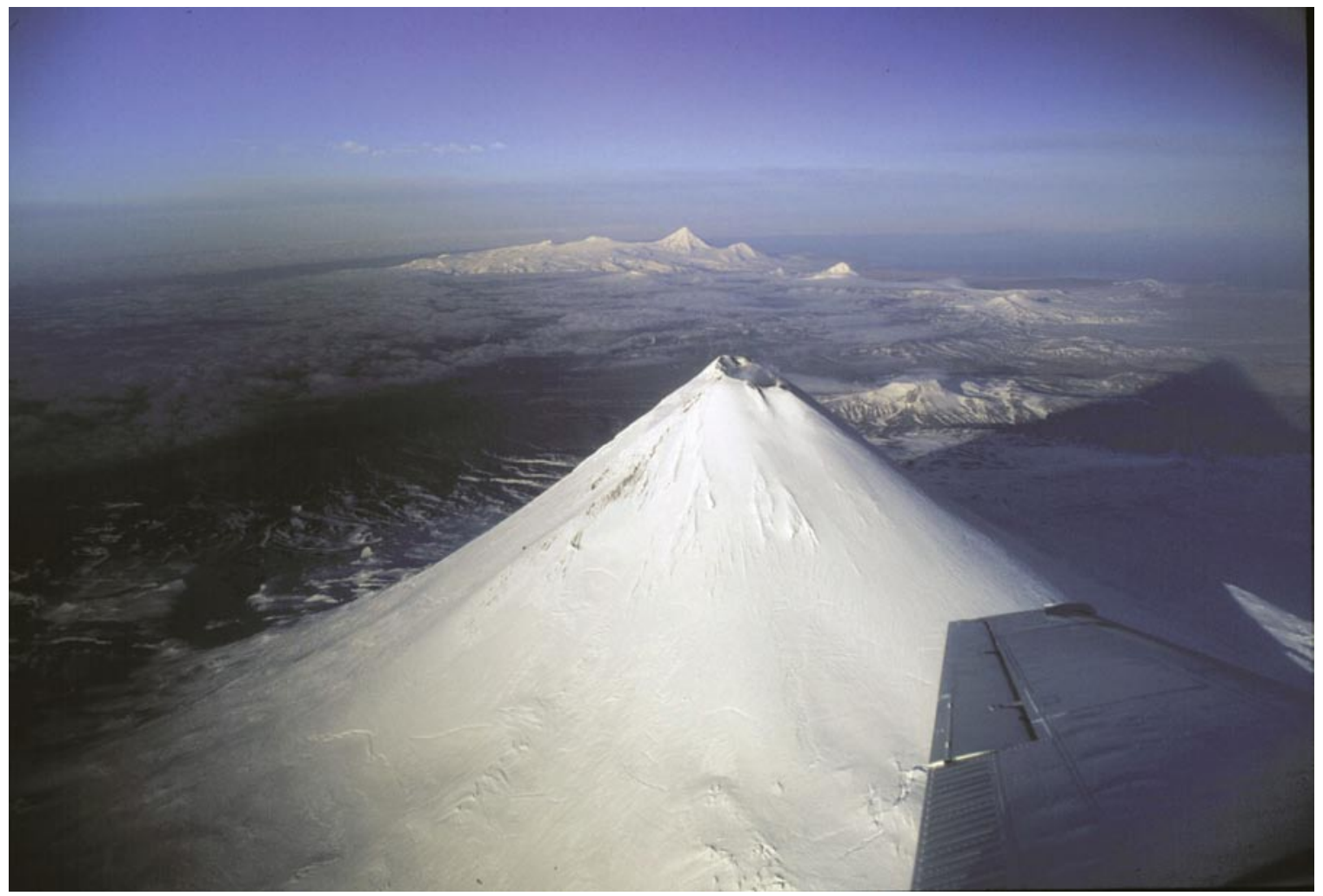

Figure 19. Oblique aerial view from the east of Shishaldin Volcano. Westdahl Volcano in the distance. Photo by C.A. Neal, March 27, 1995.

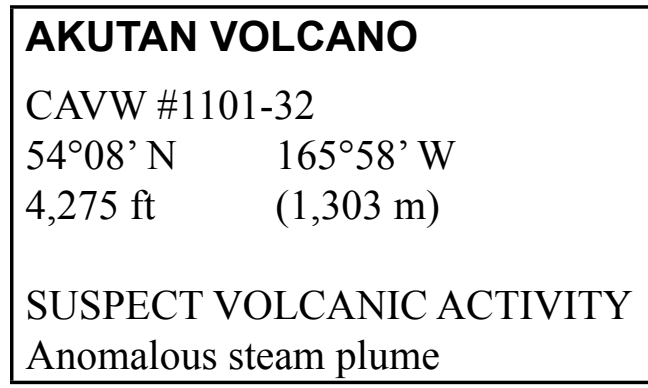

AVO received reports on October 15, 2003 from several sources - both on land and at 
sea- of increased steaming from the northeast flank of the volcano. All reports indicate that the steaming was located at about the 1,500 to $2,000 \mathrm{ft}$. elevation ( $\sim 500$ to $600 \mathrm{~m})$, and not from the summit crater or cone. A review of seismic data indicated nothing unusual. Hot Springs Bay Valley, which contains a string of thermal springs, heads on the northeast flank of Akutan, and a well-documented and long-lived fumarolic field exists at about the 1,500 ft. level (Richter and others, 1998) (figs. 20 and 21). Under favorable meteorological and visibility conditions, steam coalescing from this field can produce persistent steam clouds. AVO staff further reviewed recent seismic data and queried local residents in Akutan village. Nothing unusual was found and no further reports came forth.

Akutan is a small stratocone on the western portion of Akutan Island. The volcano is truncated by a 2-km-wide (1.2 mi) summit caldera that contains a small lake, intracaldera cone, and a stagnant glacier (Richter and others, 1998) (fig. 20). It is one of the most active of the Alaskan volcanoes with more than 20 recorded eruptions since 1790 (Miller and others, 1998). The last eruption was in 1992 (McGimsey and others, 1995) and an intense seismic swarm in March 1996 was probably the result of a magmatic intrusion (Lu and others, 2000).

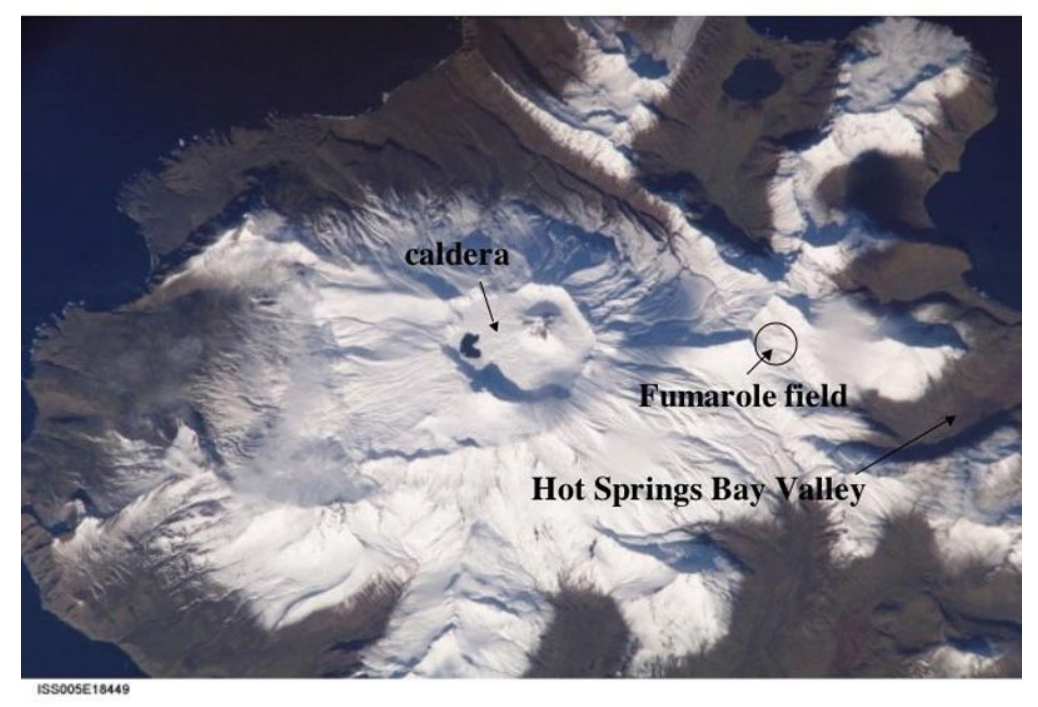

Figure 20. Photograph from space of Akutan volcano. The caldera is approximately $2 \mathrm{~km}(1.2 \mathrm{mi})$ in diameter. Image courtesy of the Image Analysis Laboratory, NASA Johnson Space Center, Earth Sciences and Image Analysis, NASA-Johnson Space Center. 25 Mar. 2005. "Astronaut Photography of Earth." Image ID ISS005E18449. 


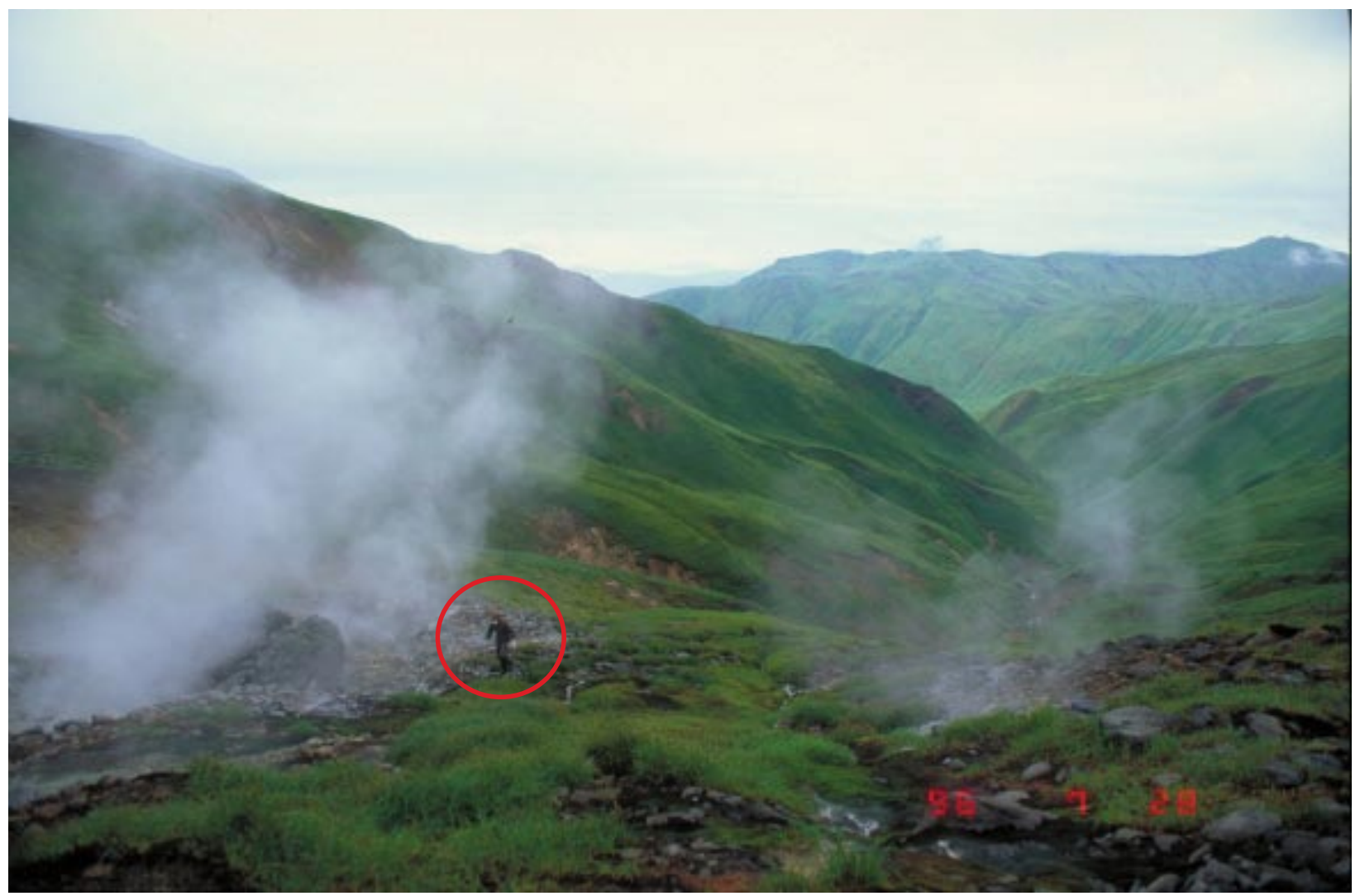

Figure 21. Bob Symonds (circled) collecting gas samples from fumaroles at the head of Hot Springs Bay, Akutan Volcano, July 28, 1996. Photograph by G. McGimsey, USGS.

\section{UN-NAMED SOURCE}

$53^{\circ} \mathrm{N} \quad 172^{\circ} \mathrm{E}$

SUSPECT VOLCANIC ACTIVITY

Suspected ash cloud

On Sunday evening, February 2, 2003, the AAWU issued a SIGMET regarding what was believed to be a dissipating ash cloud located over the western Aleutian Islands. The coordinates indicated a cloud location southwest of Attu, a non-active volcanic island, 50 nautical miles either side of a line from 53N 172E to $48 \mathrm{~N} 168 \mathrm{E}$; the cloud was estimated to be up to $35,000 \mathrm{ft}$ ASL $(\sim 10,670 \mathrm{~m})$. AVO analysis of satellite imagery indicated no ash signature and AVO concluded the cloud was an orographic weather cloud. The AAWU subsequently issued an update advising that the cloud was not volcanic in origin. 


\section{VOLCANIC ACTIVITY, KAMCHATKA PENINSULA, and the NORTHERN KURILE ISLANDS, RUSSIA}

Active volcanoes on Russia's Kamchatka Peninsula and along the Kurile Island chain pose a serious threat to aircraft in the North Pacific. By agreement with the Institute of Volcanic Geology and Geochemistry (IVGG) and the Kamchatka Experimental and Methodical Seismological Department (KEMSD, Geophysical Service), both Institutes of the Russian Academy of Sciences in Petropavlovsk, Kamchatka (fig. 22), AVO assists with global distribution of information about eruptions in Russia (Kirianov and others, 2002). The Kamchatkan Volcanic Eruption Response Team (KVERT), consisting of scientists from both IVGG and KEMSD, issues a weekly email information release that is rebroadcast by AVO to our web site and to hundreds of recipients. When volcanic activity intensifies at any Kamchatkan volcano requiring notification of aviation and other interests, KVERT sends additional updates as needed. The year 2003 marked the $10^{\text {th }}$ anniversary of KVERT operation, a milestone celebrated at an international workshop in Petropavlovsk (Neal, 2003).

Scientists with the KEMSD portion of KVERT monitor most of the frequently active volcanoes in Kamchatka and the northern Kurile Islands with one or more short period seismometers (table 5; fig. 22). In addition, KEMSD and KVERT receive visual reports and photographs of activity from scientific observers in the communities of Klyuchi (pop. 10-15,000, 45 km southwest of Sheveluch) and Kozyrevsk (pop. 2-3,000, 30 km west of Klyuchevskoy). On occasion, KVERT also receives reports from a scientific research station maintained by the Institute of Volcanology near Karymsky Volcano. Pilot reports are increasingly available from the local Civil Aviation Meteorological Center at Yelizovo Airport $20 \mathrm{~km}$ northwest of Petropavlovsk. As of the end of 2003, KEMSD operated three real-time, web-based camera systems. Images of Sheveluch, Klyuchevskoy, and Bezymianny volcanoes were available from these systems via the Internet at this URL: http://data.emsd.iks.ru/video/video.htm

Since the late 1990s, AVO satellite remote sensing scientists have shared analysis of satellite images of Kamchatka volcanoes with KVERT staff. KEMSD scientists also conduct retrieval and analysis of NOAA 16 and NOAA 17 images in Petropavlovsk-Kamchatsky via the Federal State Unitary Enterprise Kamchatkan Center of Communication and Monitoring that manages a NOAA AVHRR receiving station in Petropavlovsk. This information is incorporated into KVERT monitoring reports and hazard warnings. KVERT also received occasional processed MODIS images from colleagues at the Far East Geological Information Center of the Ministry of Natural Resources in Yuzhno-Sakhalin. In 2003, KVERT developed an agreement with this group to receive processed images of Kamchatkan and northern Kurile volcanoes on a fairly regular basis.

In 2003, there were continued high levels of volcanic activity at volcanoes in Kamchatka. In particular, AVO relayed KVERT information about unrest at Sheveluch, Klyuchevskoy, Bezymianny, and Karymsky volcanoes (fig. 22). KVERT also responded to a brief explosive eruption at Chikurachki Volcano on Paramushir Island in the northern Kuriles (during this eruption, KVERT formally declared responsibility for reporting eruptions on the Northern Kurile islands of Paramushir and Atlasova; mention of Chikurachki in the weekly updates began on May 9 and continued until July 11 by which time the eruption had apparently ended.)

For each of these periods of heightened activity, AVO relayed information received from KVERT to aviation and weather authorities in the U.S, Canada, and elsewhere through standard 
notification procedures. On occasion AVO staff communicated directly with KVERT to clarify information and assist users in interpreting data coming from KVERT.

The following summaries contain reported events according to Kamchatkan local dates and Coordinated Universal Time (UTC), which equals ADT +8 hrs and AST +9 hrs unless otherwise noted. The equivalent local Kamchatkan time (herein referred to as Kamchatkan Daylight or Standard time) is always 21 hours ahead of Alaska time. This compilation is derived from a number of sources including KVERT weekly updates, unpublished AVO internal files and documentation, and Global Volcanism Program Volcanic Activity reports.

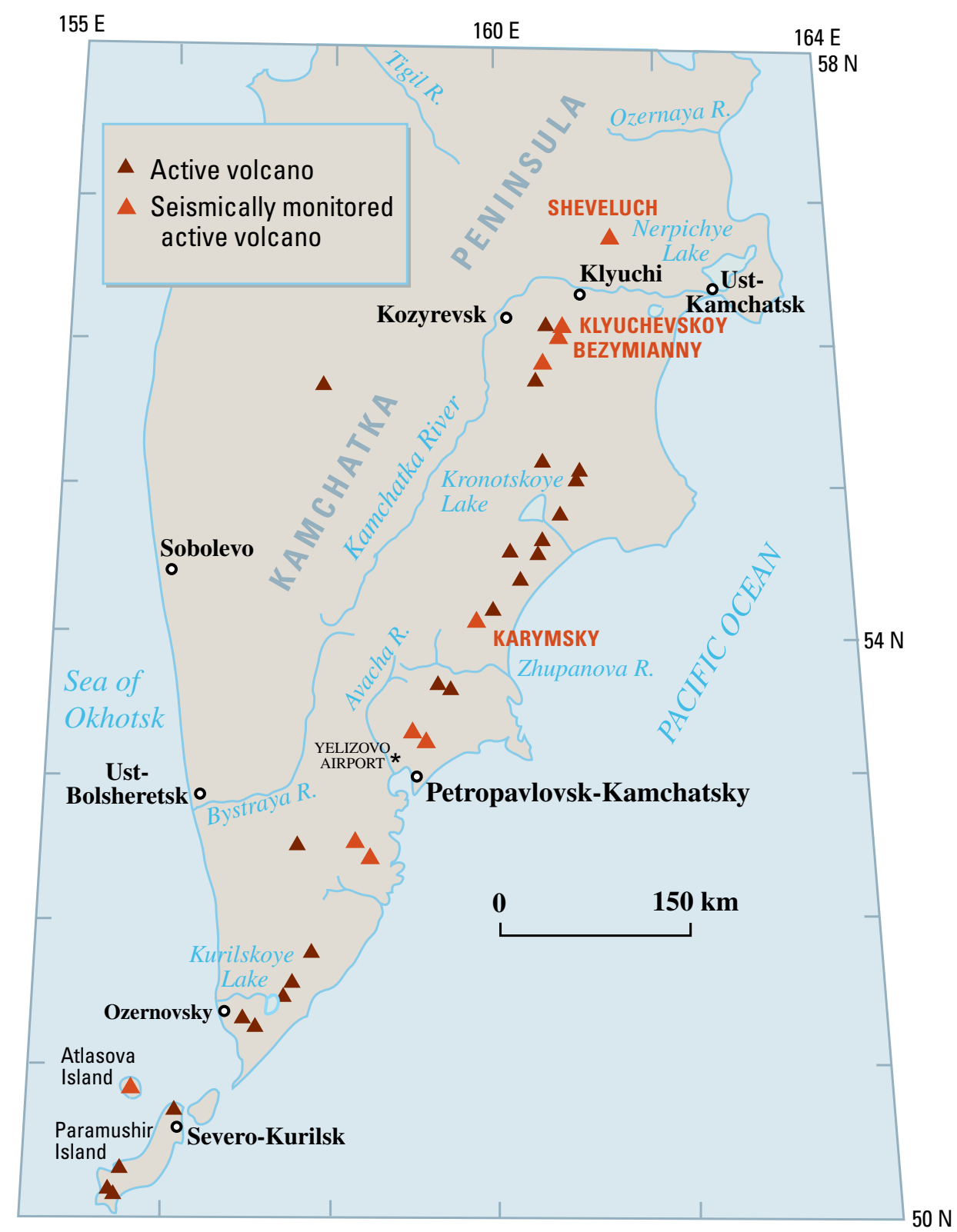

Figure 22. Map of the Kamchatka Peninsula and northern Kurile Islands. Volcanoes discussed in this report are labeled in red. 


\section{SHEVELUCH VOLCANO}

CAVW\# 1000-27

$56^{\circ} 38^{\prime} \mathrm{N} \quad 161^{\circ} 21^{\prime} \mathrm{E}$

$3,283 \mathrm{~m} \quad(10,768 \mathrm{ft})$

elevation of the lava dome $\sim 2500 \mathrm{~m}(\sim 8,200 \mathrm{ft})$

CONTINUED DOME GROWTH AND COLLAPSE

Occasional ash explosions and/or dome collapse and associated pyroclastic flows, ash plumes, ash falls

Eruptive activity related to primarily endogenous (?) growth of the lava dome at Sheveluch Volcano continued intermittently through 2003, but at a lower level of intensity than in 2002. KVERT maintained Level of Concern Color Code YELLOW for the entire year however, their weekly updates noted, "... at any time, with little warning, explosions could produce pyroclastic flows and ash plumes as high as $7-10 \mathrm{~km}(23-33,000 \mathrm{ft})$ as well as localized ash falls."

At the beginning of 2003, the active dacite lava dome within the Sheveluch amphitheater stood $494 \mathrm{~m}(1,620 \mathrm{ft})$ tall, $\sim 1,500 \mathrm{~m}(4,920 \mathrm{ft})$ across at the base, and contained some $274 \mathrm{mil}-$ lion $\mathrm{m}^{3}$ (358 million $\mathrm{yd}^{3}$ ) of lava (Yury Demyanchuk, unpublished data, 2003; fig. 23). Periodic explosions from the dome were often captured on a digital camera in the community of Klyuchi located $46 \mathrm{~km}$ southwest of the volcano (http//data.emsd.iks.ru/videosvl/videosvl.htm). Seismicity related to these explosions was recorded on the nearest seismic station located $8.5 \mathrm{~km}$ southwest of the crater. The most energetic of these produced single pulses of ash that rose between 1 and $6 \mathrm{~km}(3,300$ and 20,000 ft) above the dome or as high as $8.5 \mathrm{~km} \mathrm{(5} \mathrm{mi)} \mathrm{ASL} \mathrm{(28,000} \mathrm{ft).}$ These estimated elevations are based on direct measurements of the ash column or, when weather or darkness precluded visual confirmation, inferred from interpretations of seismicity. Many explosions were also accompanied by partial collapse of the lava dome, producing pyroclastic flows that traveled across the debris fan extending southwest from the crater. Light ash fall in the immediate vicinity of the volcano occurred during most of these events and during the more significant explosions, ash deposits extending several 10s of $\mathrm{km}$ downwind were visible in satellite imagery (fig. 24). 


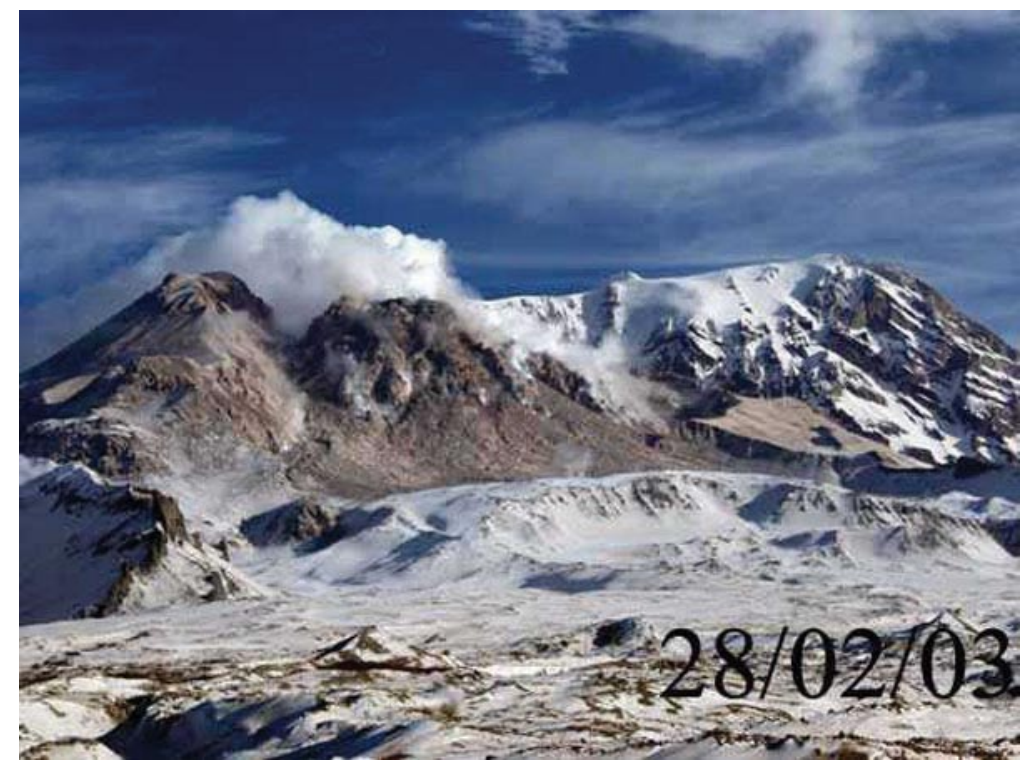

Figure 23. A cloud of steam and volcanic gas emanates from the summit of the active lava dome within the amphitheater of Sheveluch Volcano on February 28, 2003. View is to the northeast across the pyroclastic debris fan formed by successive collapse events from the lava dome. The dome is approximately $500 \mathrm{~m}$ high in this image (Yury V. Demyanchuk, written communication 2003). Image courtesy Yury V. Demyanchuk, KEMSD.

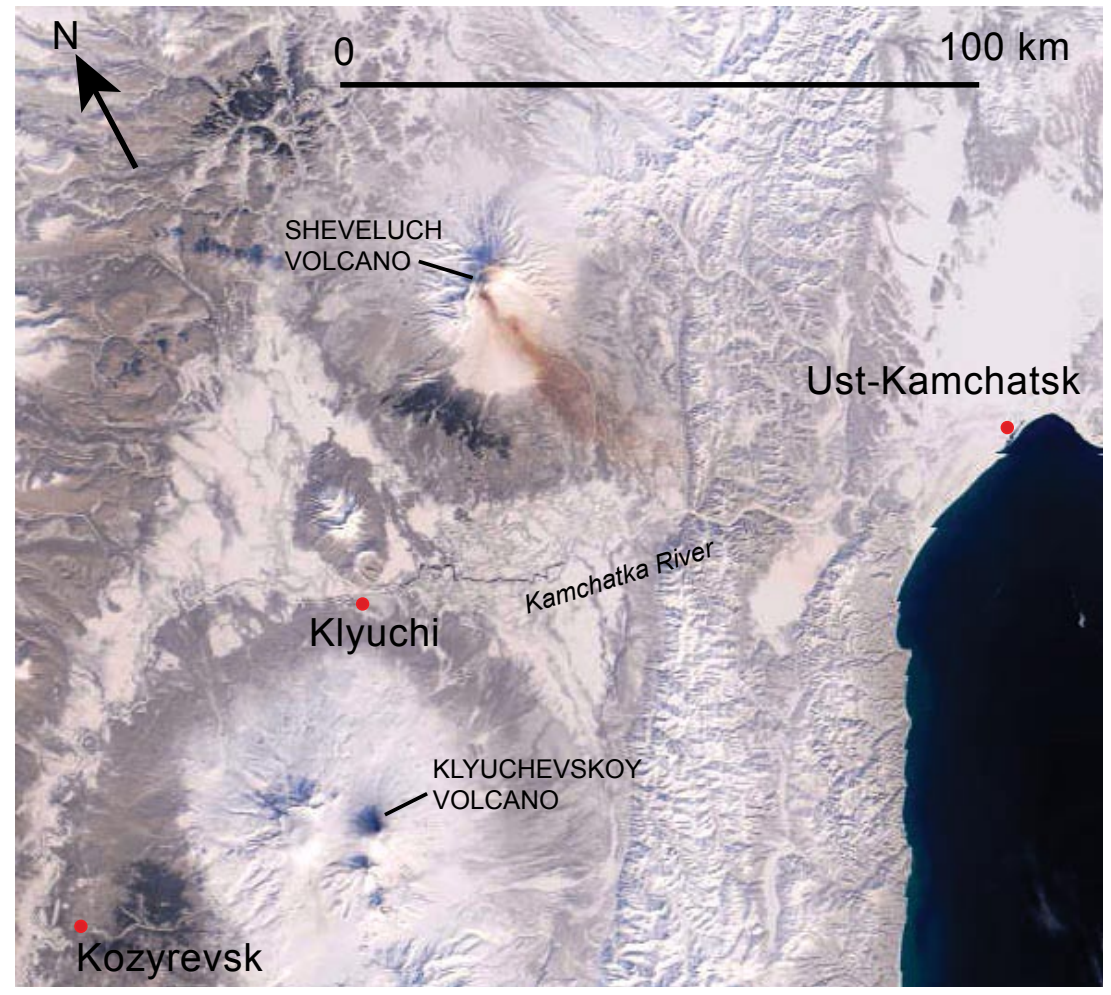

Figure 24. MODIS image of Sheveluch (top) and the Klyuchevskoy Group (bottom) of volcanoes in Kamchatka on March 28, 2003 (image ID 2003087005501.250m). A recent ash fall deposit extending south from the active lava dome at Sheveluch shows up as a distinctive brown fan-shaped pattern on the snow-covered terrain. Body of water at lower right is Kamchatka Bay. The Kamchatka River separates Sheveluch from Klyuchevskoy. 
In mid-February and early March, several energetic explosions from the lava dome sent

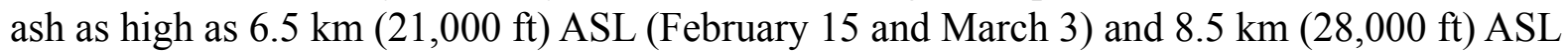
(March 8). A lahar produced during the March 3 event traveled at least $40 \mathrm{~km}$ (25 mi) south to the Kamchatka River significantly damaging a road and threatening access to the village of Ust-Kamchatsk (fig. 24). Yury Demyanchuk of KEMSD reported ash fall as far as $30 \mathrm{~km}$ (19 mi) northwest of the volcano and described round ash and snow balls up to $10 \mathrm{~cm}$ (4 in) across rolling across the tundra in strong surface winds.

The number of these explosions observed and detected seismically varied from as many as 25 per week in early January 2003 to several per week in June. By the end of June, the number of explosions had diminished and seismicity remained at or just above background levels through the end of the year. No incandescence was reported in the vicinity of the active lava dome. However, as viewing conditions allowed, satellite imagery of Sheveluch detected a persistent thermal anomaly in AVHRR imagery.

During periods of lower seismicity and in between explosive events, a fumarolic plume was occasionally visible over the lava dome rising typically to altitudes of 50-2,000 m (160$6,500 \mathrm{ft}$ ) above the dome (fig. 23). At times, these plumes were visible extending downwind many $10 \mathrm{~s}$ of $\mathrm{km}$ based on ground observer reports; some were visible on satellite imagery if conditions allowed. On April 27, AVHRR imagery showed a gas and steam plume trailing 110 $\mathrm{km}$ (68 mi) downwind from the lava dome.

Sheveluch Volcano is one of the largest and most active volcanoes in Kamchatka with at least 60 large eruptions during the Holocene (Bogoyuvlenskaya and others, 1985; Ponomareva and others, 1998). The northernmost active volcano on the Peninsula, historical eruptive activity has been characterized by extrusion of a dacite lava dome and periodic explosive collapse, often producing coarse pyroclastic avalanches. Its current protracted, episodic phase of lava dome growth began in August of 1980.

\section{KLYUCHEVSKOY VOLCANO}

CAVW\# 1000-26

$56^{\circ} 03^{\prime} \mathrm{N} \quad 160^{\circ} 38^{\prime} \mathrm{E}$

$4,750 \mathrm{~m} \quad(15,589 \mathrm{ft})$

\section{VULCANIAN, STROMBOLIAN ERUPTION}

Periods of elevated seismicity, ash explosions, strombolian fountaining, incandescence and associated ash fall, ash clouds.

In 2003, the ongoing eruption at Klyuchevskoy Volcano increased in intensity and frequency of ash-producing events. The volcano began the year at Level of Concern Color Code YELLOW following a brief, energetic episode of ash production in late December when KVERT briefly declared color code ORANGE (Neal and others, 2005). KVERT again declared ORANGE on January 6, 2003, after noting a thermal anomaly in satellite imagery and a flowage deposit on the flank of the volcano. Seismicity remained above background, however, no eruption ensued and KVERT reverted to YELLOW on January 10.

Over the next several months, Klyuchevskoy seismicity remained above background with several to tens of earthquakes detected below the volcano each day. Spasmodic tremor was also 
recorded on seismic stations surrounding the volcano, and a persistent fumarolic plume rose 50 meters to $1.5 \mathrm{~km}(160-4,900 \mathrm{ft})$ above the summit and trailed as far as $60 \mathrm{~km}(37 \mathrm{mi})$ downwind. Possible new deposits of ash on the flanks of the volcano were noted in satellite imagery in late February. In late March, the amplitude of tremor increased. Explosions containing ash were

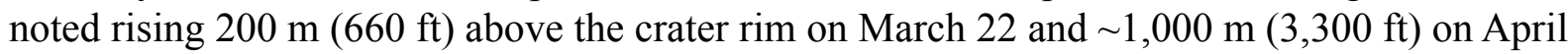
17 (fig. 25). In Mid-April, the frequency of these ash explosions accelerated, culminating in a significant explosion on May 13 that prompted a pilot report of ash to $8.5 \mathrm{~km}(28,000 \mathrm{ft})$ ASL. Based on the increasing activity and height of the May 13 ash plume, KVERT declared color code ORANGE on May 14 where it remained for the remainder of 2003.

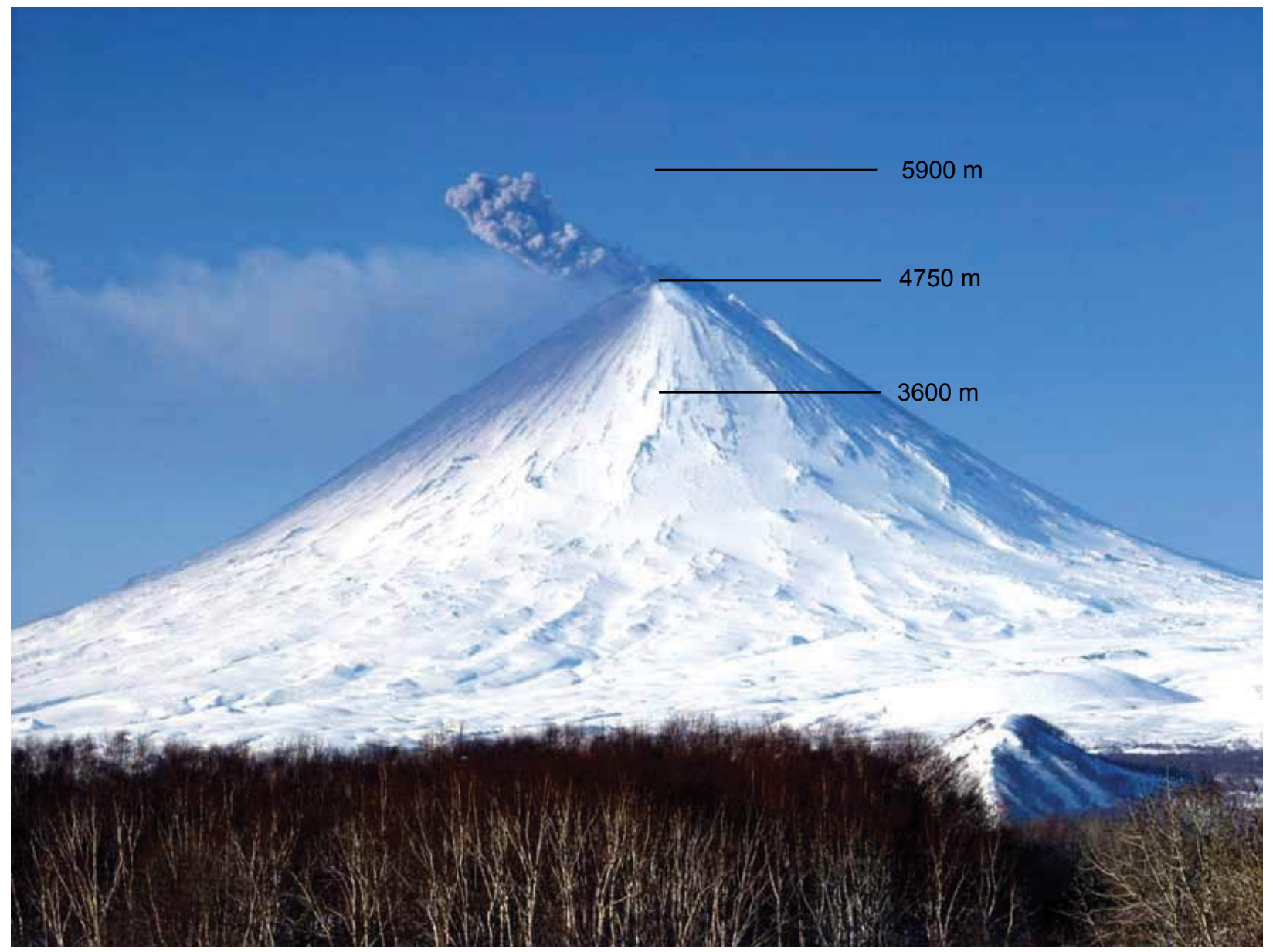

Figure 25 Small ash plume rises $\sim 1,000 \mathrm{~m}(3,300 \mathrm{ft})$ above the summit of Klyuchevskoy Volcano on April 17,2003 . View is to the south from Klyuchi. Image courtesy Yury V. Demyanchuk, KEMSD.

During these more vigorous vulcanian explosions, dilute ash clouds trailed downwind as far as $250 \mathrm{~km}$ as detected in satellite imagery. Beginning on May 16, a strong thermal anomaly associated with the summit crater was noted and on May 17, observers reported glow from incandescent material in the Klyuchevskoy crater, the first time since the major eruption in 1994 (Miller and Casadevall, 2000). 
Explosions sent ash plumes rising hundreds of meters to $2 \mathrm{~km}$ above the cone intermittently through the end of the year. New ash on the flanks of the volcano and pulsing glow at night (fig. 26), sometimes accompanied by rumbling and explosions, were reported by scientific observers. In late August, KVERT received word of strombolian activity hurling bombs hundred meters above the crater rim. During quiescent intervals, a gas and steam plume rose up to several $\mathrm{km}$ above the crater and drifted downwind. A persistent thermal anomaly was noted in AVHRR imagery when weather conditions allowed. Seismicity remained well above background for the entire year.

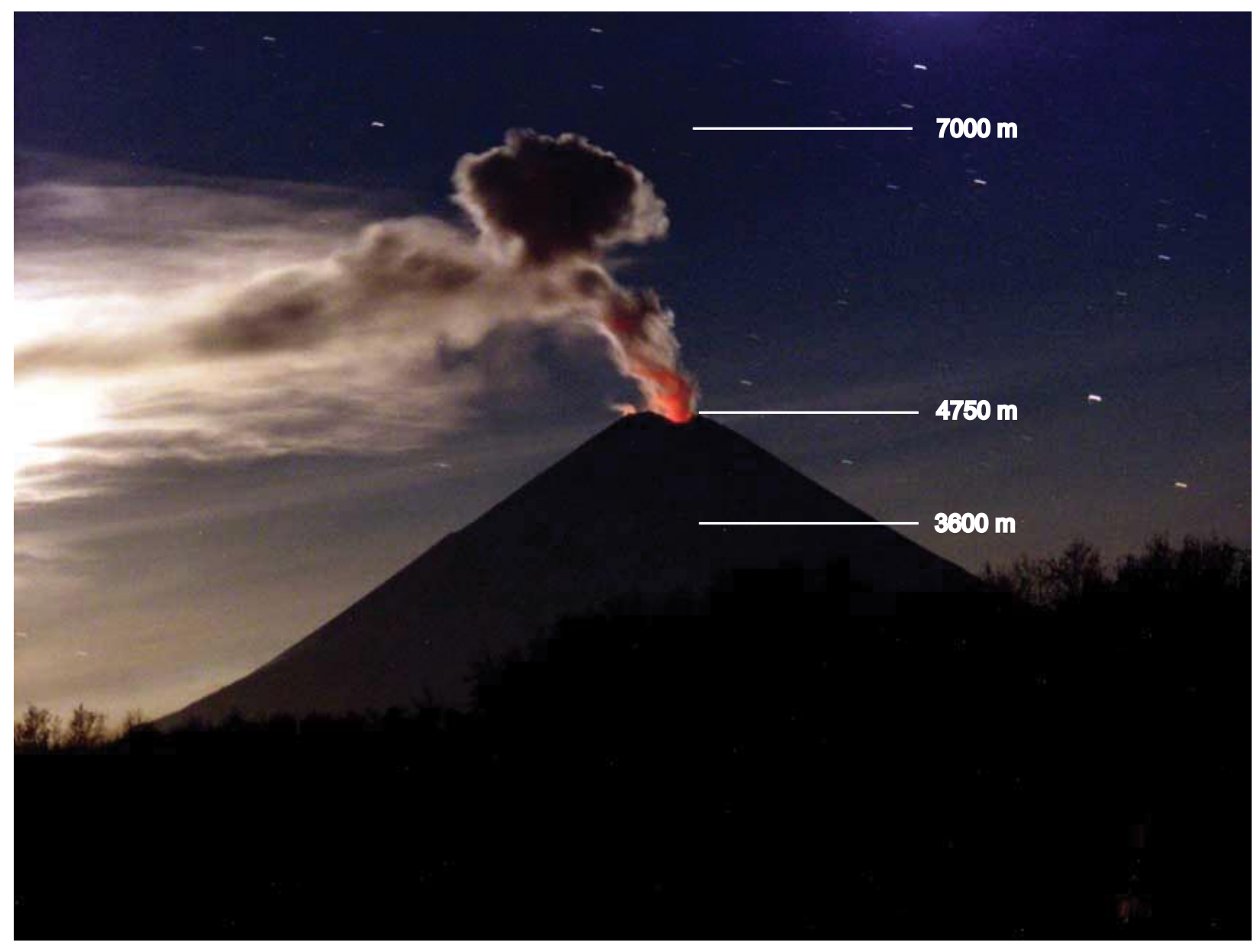

Figure 26. Nighttime view of Klyuchevskoy Volcano on October 4, 2003. Incandescence related to strombolian activity within the summit crater reflects in the fumarolic plume rising $\sim 2,000 \mathrm{~m}(6,600 \mathrm{ft})$ over the summit of the volcano. View is to the southwest from Klyuchi. Image courtesy Yury V. Demyanchuk, KEMSD.

Klyuchevskoy is a classic, symmetrical stratovolcano and, at 4,750 m (15,580 ft), it is the highest of the active European and Asian volcanoes. Klyuchevskoy is frequently active with vulcanian to strombolian explosions and occasional lava flow production from the main vent in the steep-walled summit crater or from flank vents (Khrenov et al., 1991). Explosive eruptions are recorded in nearly every decade and at multiple times during most years since the early $1700 \mathrm{~s}$ 
(Simkin and Siebert, 1994). Its most recent significant eruption was September 30-October 1, 1994, when an explosive event sent an ash cloud more than 1,000 km to the south and east across the North Pacific (Miller and Casadevall, 2000).

\section{BEZYMIANNY VOLCANO}

CAVW\# 1000-25

$55^{\circ} 58^{\prime} \mathrm{N} \quad 160^{\circ} 36^{\prime} \mathrm{E}$

$2,800 \mathrm{~m} \quad(9,187 \mathrm{ft})$

CONTINUED LAVA DOME GROWTH

Minor dome growth in early January following late December 2002 event; significant explosion in late July follows reappearance of thermal anomaly.

Declining seismicity following the late December 2002 event at Bezymianny (Neal and others, 2001) led KVERT to reduce the Level of Concern Color Code from YELLOW to GREEN on January 3, 2003. Despite this, their weekly update notes that active extrusion likely continued at the lava dome within the summit amphitheater. A weak thermal anomaly visible in satellite imagery persisted for the first week of January. Seismicity remained at low levels until late July.

On July 26 with only weak seismic precursors, a significant explosion sent ash to an estimated $8 \mathrm{~km}(26,000 \mathrm{ft})$ ASL above Bezymianny. A pilot report noted ash as high as $11 \mathrm{~km}$ $(36,300 \mathrm{ft})$ and KVERT declared color code RED. KVERT scientists inferred that a pyroclastic flow had descended the flank of the volcano immediately following the explosion.

Seismicity dropped significantly and KVERT reduced the color code to ORANGE on the July 28, YELLOW on July 29, and GREEN on August 8. Satellite images continued to show a small thermal anomaly in the vicinity of the dome for several days following the explosive event.

In October 1955, Bezymianny Volcano emerged from a 900-1,000 year period of quiescence commencing an explosive eruption that culminated on March 30, 1956, with the catastrophic failure of the eastern flank and debris avalanche and lateral blast. Since then, lava extrusion has produced a dome that periodically collapses generating pyroclastic flows and short-lived ash plumes (Girina and others, 1993; Belousov and others, 2002). Seismic monitoring of the current eruption is difficult because of the ongoing, energetic seismicity of near-by Klyuchevskoy Volcano and the limited station distribution around Bezymianny.

\section{KARYMSKY VOLCANO}

CAVW\# 1000-13

$54^{\circ} 03^{\prime} \mathrm{N} \quad 159^{\circ} 27^{\prime} \mathrm{E}$

$1,486 \mathrm{~m} \quad(4,876 \mathrm{ft})$

LONG-LIVED STROMBOLIAN/VULCANIAN ERUPTION INTENSIFIES IN LATE 2003

Intermittent explosions, localized ash fall, lava extrusion, rock avalanches, degassing.

Karymsky remained at Level of Concern Color Code YELLOW for the first eight weeks of 2003. Seismicity remained largely above background with 100-200 shallow events per day 
detected on the local seismic network. Scientific observers reported gas and ash explosions rising up to $1 \mathrm{~km}(3,300 \mathrm{ft})$ above the volcano and vigorous gas and sometimes ash emission episodes lasting 5-10 minutes. Satellite images continued to show a thermal anomaly at the volcano, although the strength of the anomaly began to decline in late January. On February 28, following several weeks of near-background seismicity and the absence of a thermal anomaly in satellite imagery, KVERT reverted to color code GREEN and speculated that the 7-year-long eruption might be over.

The pause in activity lasted less than a month and KVERT returned to YELLOW on March 21 following renewed ash explosions, avalanching of debris, and ash fall within $30 \mathrm{~km}$ of the volcano. Another downgrade to GREEN lasted from April 4-April 18. From mid-April through late August, between 80 and 330 shallow explosion signals were recorded at local seismic stations each day. Accompanying ash clouds rose typically 1-2.5 km (3,300-8,200 ft) above the volcano and were either directly observed or inferred on the basis of seismic signal characteristics (fig. 27). A particularly strong seismic event on July 16 may have resulted from avalanching related to a new lava flow on the flank of the volcano.

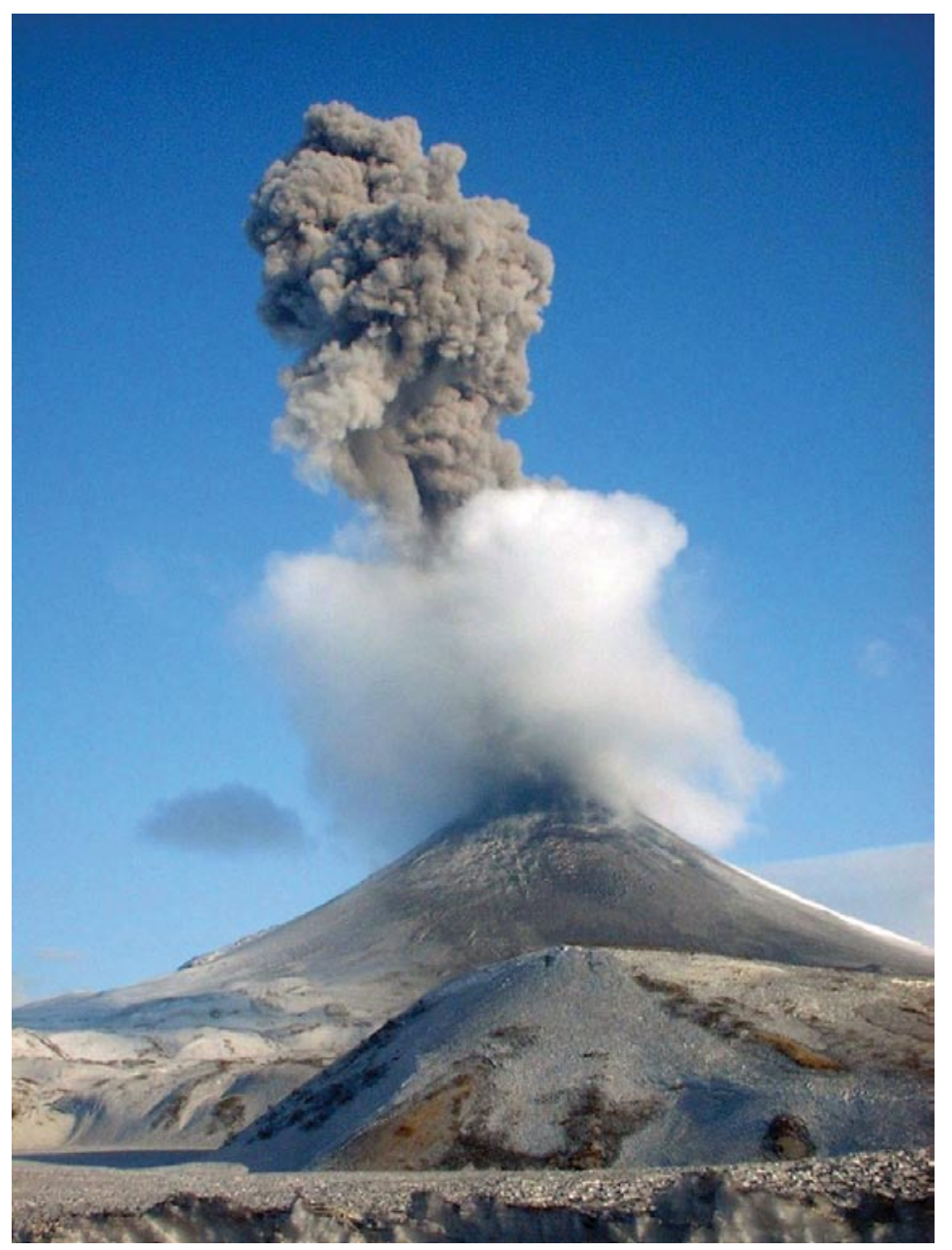

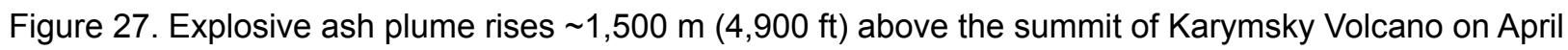
24, 2003. Ash fall from earlier events blankets snow in the foreground. View is to the northwest. Image courtesy V. Bachtiarov, KEMSD. 
Ash fall from the more vigorous of explosions extended tens of $\mathrm{km}$ downwind and avalanches of debris down the steep flanks of the volcano were common (fig. 28). A thermal anomaly coincident with the cone was visible on AVHRR satellite images whenever viewing conditions allowed. During quiescent periods between explosions, a gas and steam plume trailed downwind up to $115 \mathrm{~km}(70 \mathrm{mi})$.

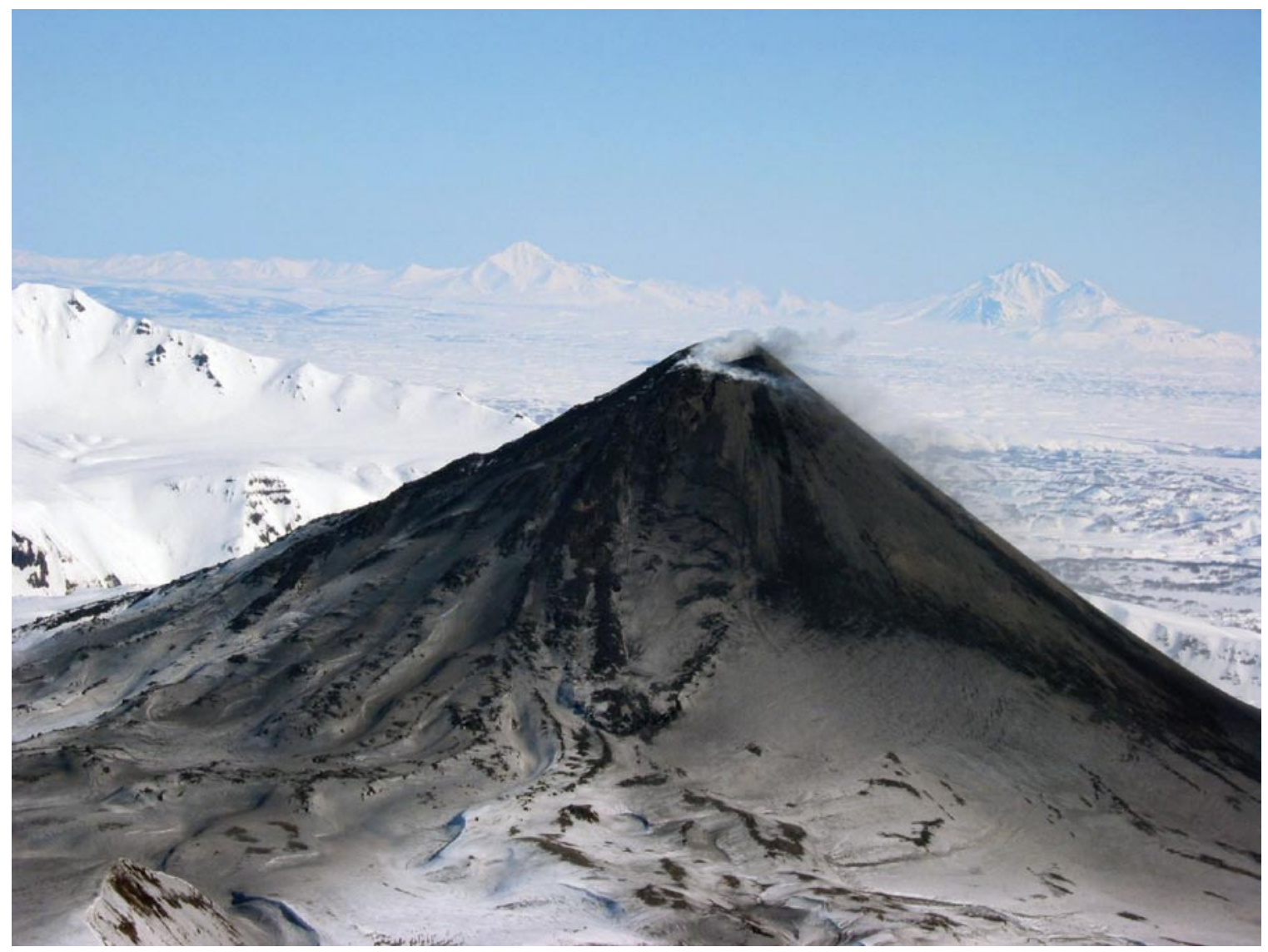

Figure 28. Helicopter view of Karymsky Volcano on April 19, 2003. A small gas and steam plume rises from the active summit crater. Ash fall from explosive events of the past several days blankets the flanks of Karymsky. View is to the northeast. Semiachik volcanoes are visible on the skyline. Photograph by C. A. Neal, USGS.

KVERT switched between YELLOW and ORANGE several times and settled on ORANGE from late October to the year's end after several explosions reached more than $3 \mathrm{~km}$ above the crater. Through December, as many as 250 explosions were recorded each day with ash plumes reaching as high as $6 \mathrm{~km}(19,700 \mathrm{ft})$ ASL. A persistent thermal anomaly and frequent ash-poor plume in satellite images attested to the ongoing eruption for the remainder of 2003.

The current phase of unrest began with increasing seismicity in mid-April 1995 and culminated in an explosive eruption that began on January 1, 1996, simultaneously at Karymsky volcano and from a vent at the north part of Karymsky Lake about $10 \mathrm{~km}$ (6 mi) distant (Belousov and Belousov, 2001; McGimsey and Wallace, 1999). Karymsky usually issues a continuous steam plume and is the most active volcano on the Kamchatkan Peninsula (Simkin and Siebert, 1994). Explosive and effusive-explosive eruptions of andesitic tephra and lava flows alternating with periods of repose are typical of Karymsky (Ivanov and others, 1991). 


\begin{tabular}{l}
\hline ALAID VOLCANO Atlasova Island, Northern Kuriles, Russia \\
CAVW\# 0900-39 \\
$50^{\circ} 52^{\prime} \mathrm{N} \quad 155^{\circ} 34^{\prime} \mathrm{E}$ \\
$2,339 \mathrm{~m} \quad(7,674 \mathrm{ft})$ \\
SUSPECT VOLCANIC ACTIVITY \\
Persistent tremor determined to be wind noise.
\end{tabular}

On November 4, 2003, KVERT raised the Level of Concern Color Code for Alaid Volcano to YELLOW based on the appearance of spasmodic tremor at the single seismic station located on the small, island volcano (fig. 29). This tremor continued steadily over the next month accompanied by small local earthquakes. Cloudy weather precluded any satellite looks at the volcano until mid-December; no anomalies indicating the presence of ash or elevated surface temperatures were noted. Upon further examination of the records, KEMSD concluded that the signal was likely a result of storm noise and did not represent anything of volcanologic significance. KVERT returned Alaid to GREEN on December 19.

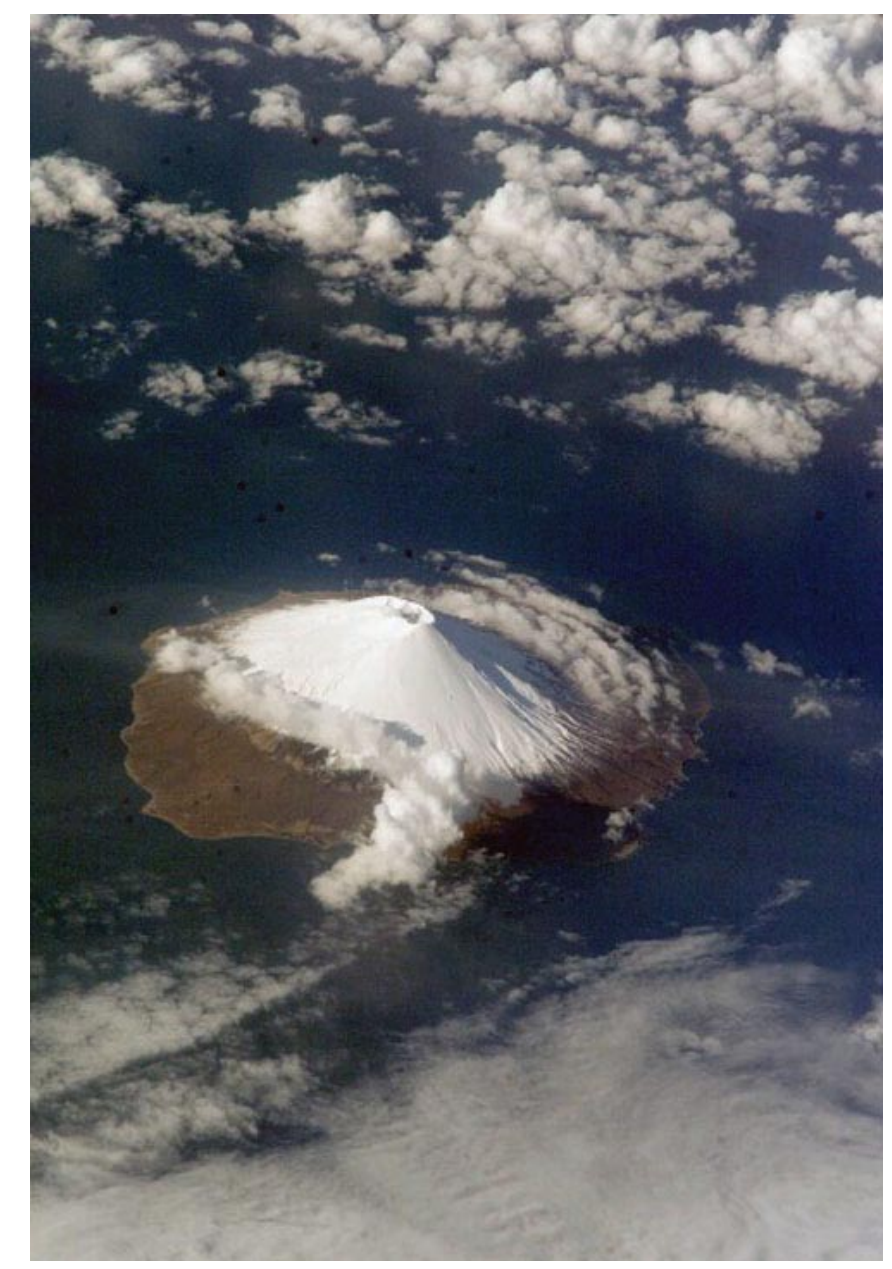

Figure 29. Oblique view (south at top) of Alaid Volcano from Earth orbit. Photograph courtesy of NASA. International Space Station image ID ISS005E19202. 
Alaid Volcano is a symmetrical stratovolcano that forms circular Atlasova Island in the Sea of Okhotsk approximately $70 \mathrm{~km}(43 \mathrm{mi})$ west of the tip of the Kamchatka Peninsula (fig. 22). Gorshkov (1970) describes a number of significant historical eruptions including a submarine eruption at the eastern shoreline of the volcano in 1933-34. Possible eruption reports in 1997 (McGimsey and Wallace, 1999) and 1996 (Neal and McGimsey, 1997) proved to be false (V. Kirianov, written communication 2000). The last known eruption of Alaid was in 1981 and is said to be among the largest of historical eruptions in the Kuriles (Simkin and Siebert, 1994). Although poorly documented, satellite imagery of the 1981 event shows an ash plume stretching across much of the north Pacific, demonstrating the hazard this volcano poses to air traffic in the region (fig. 30). KEMSD monitors the volcano with a single telemetered short-period seismometer installed in August 2001. Difficult access to this remote site has prevented maintenance visits resulting in several long data gaps (table 5.)

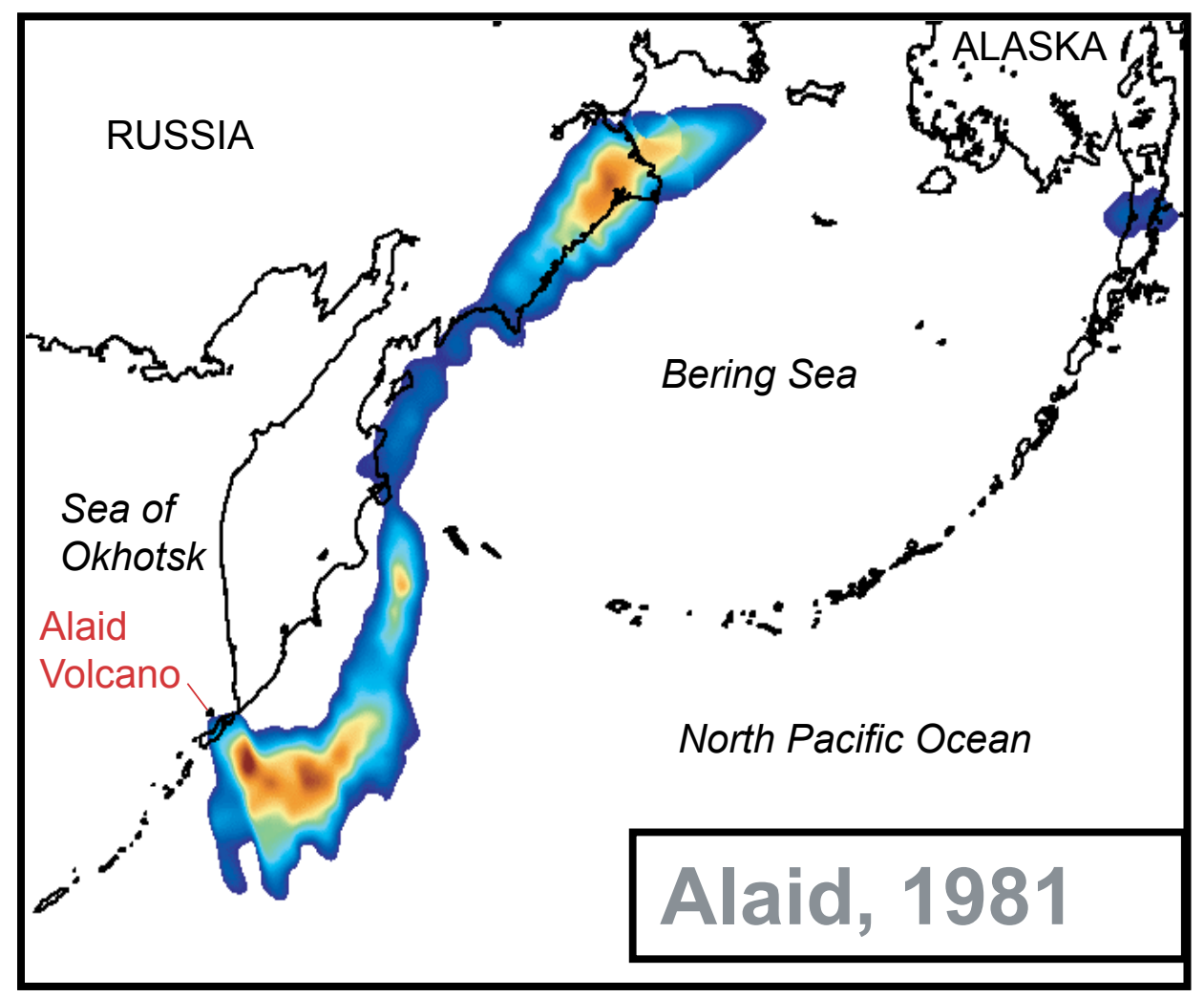

Figure 30. TOMS aerosol index image collected on April 28, 1981 showing the ash and gas cloud generated by the eruption of Alaid Volcano in the northern Kurile Islands. Graphic courtesy D. Schneider, USGS. 


\section{CHIKURACHKI VOLCANO Paramushir Island, Northern Kuriles, Russia}

CAVW\# 0900-36

$50^{\circ} 20^{\prime} \mathrm{N} \quad 155^{\circ} 27^{\prime} \mathrm{E}$

$1,816 \mathrm{~m} \quad(5,958 \mathrm{ft})$

\section{STROMBOLIAN /VULCANIAN ERUPTION}

Short-lived eruption January 25 through April or May. Ash fall as far as $130 \mathrm{~km}(80 \mathrm{mi})$ from the volcano; ash plumes reach an estimated $6 \mathrm{~km}(19,700 \mathrm{ft})$ ASL.

AVO staff scientist Dave Schneider first noted an unmistakable eruption plume from Chikurachki Volcano in the northern Kuriles during routine analysis of North Pacific GMS satellite imagery at approximately 11:00 am ADT on the morning of April 18, 2003. Subsequently, we learned that KVERT had received a report of possible eruptive activity at Chikurachki 24 hours earlier and had contacted the local Aviation Meteorological Center. However, since an eruption could not be confirmed, no hazard warning was issued. Reports received later indicated that explosions had indeed been heard in parts of Paramushir Island, and ash fall had occurred on April 17 in the towns of Podgorny and on Cape Vasilev; fig. 31.]

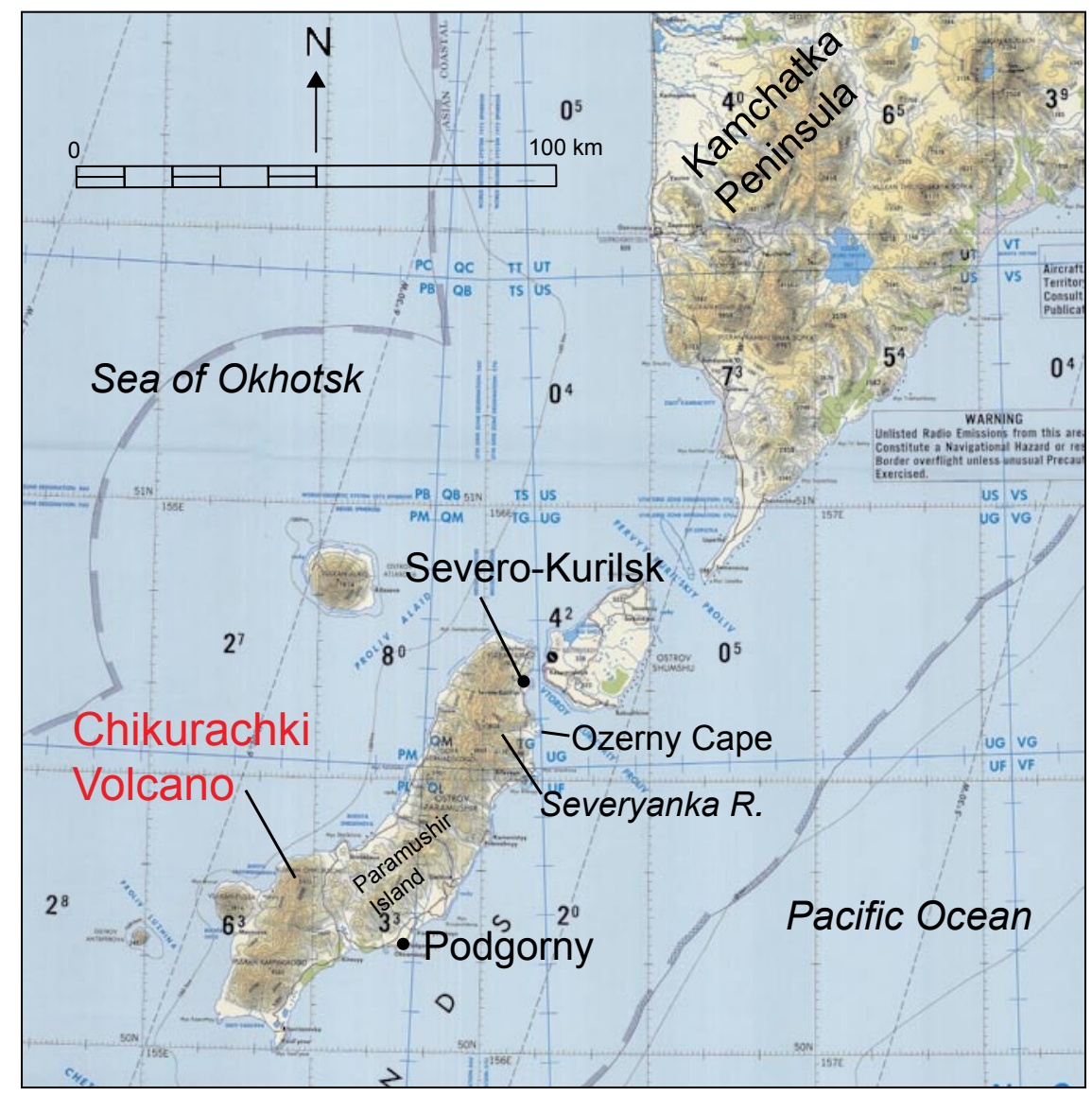

Figure 31. Map of northern Kurile Islands and southern portion of Kamchatka Peninsula. From National Oceanic and Atmospheric Administration Tactical Pilotage Chart ONC-E10C, scale 1:500,000. 
Following protocol, AVO conducted an initial call-down notification to aviation and meteorological authorities regarding this eruption prior to receipt of a KVERT Information Release. The position of this ash cloud's potential downwind trajectory across North Pacific air routes prompted much interest among the FAA, NWS, and airlines regarding the eruption. Over the course of the next several hours, a series of formal warning messages were relayed through aviation and meteorological channels. The first KVERT Information Release describing what was known about the event was released about 12 hours after the eruption began.

Based on AVO satellite analysis on the morning of April 18, at least three separate pulses of activity produced ash clouds that moved southeast. Model estimates of ash cloud height suggested a maximum elevation of 25,000 feet ASL. By late morning, a continuous, lower level plume of ash emanated from the volcano and extended south; ash was traceable to a distance of $250 \mathrm{~km}$ (155 mi) or more.

Over the next several weeks, observers on Paramushir Island continued to note strombolian/vulcanian explosions at the volcano sending ash up to an estimated $1 \mathrm{~km}(3,300 \mathrm{ft})$ above the summit. Frequent cloudy conditions hampered satellite tracking of the ash. However, intermittently ash clouds were visible on AVHRR and other imagery extending as far as $300 \mathrm{~km}$ (190 mi) from the volcano (fig. 32). Prevailing winds carried the ash predominantly east and southeast. At no time were plume and cloud heights estimated to be in excess of $\sim 15,000 \mathrm{ft}(4.5 \mathrm{~km})$ ASL. Only weak thermal anomalies were detected over the course of the eruptive phase suggesting minimal effusive activity at the volcano. 


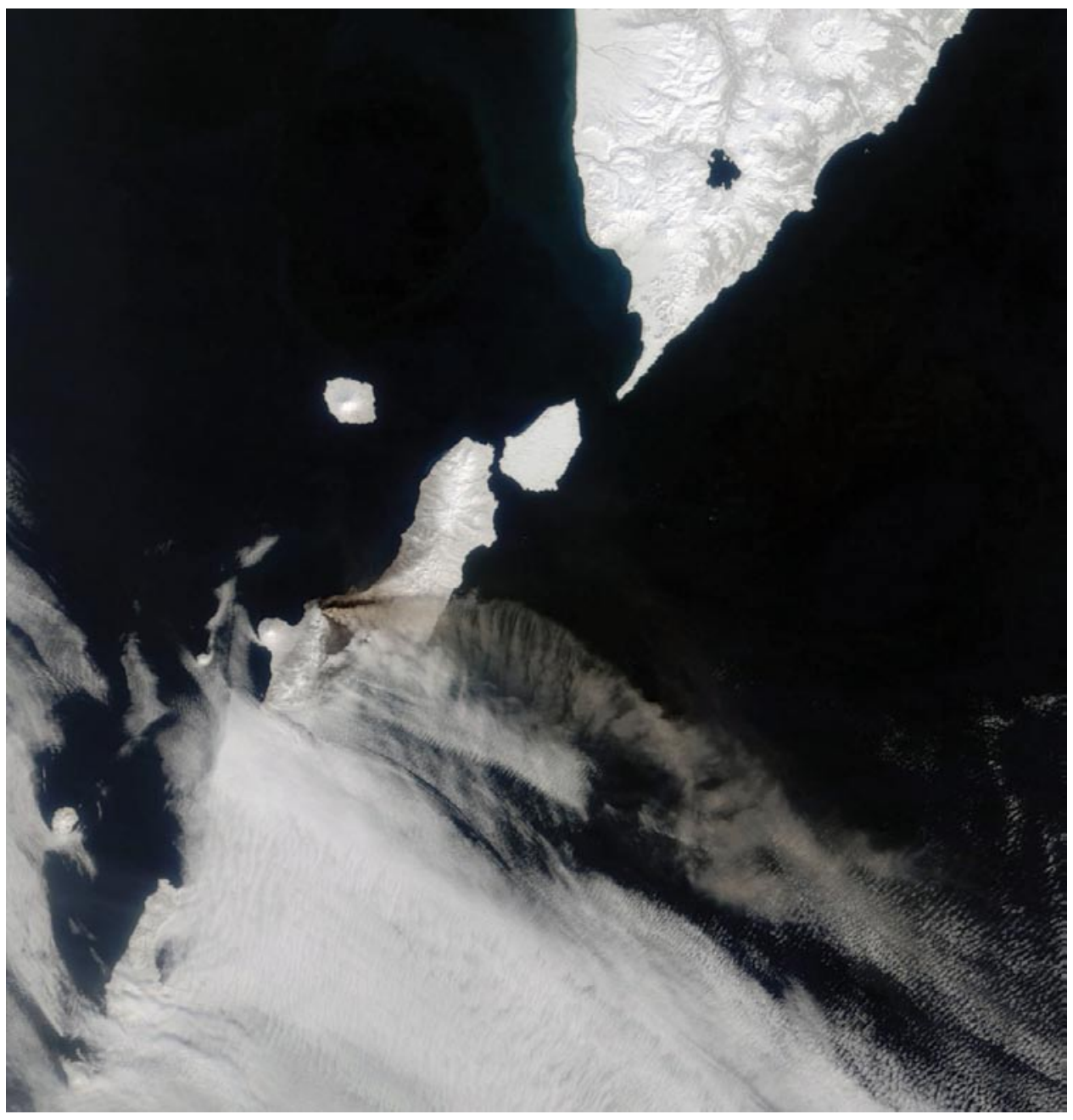

Figure 32. MODIS image of erupting Chikurachki Volcano on April 24, 2003. Ash plume emanating from the volcano trails to the southeast at least $150 \mathrm{~km}(95 \mathrm{mi})$.

No Level of Concern Color Code was used initially for this eruption because KVERT did not seismically monitor Chikurachki. However, because it was clear from observer reports and satellite imagery that this eruption was of concern to aviation, KVERT assigned a color code of ORANGE on May 9 in its weekly Information Release. Ash fall on Paramushir Island was noted at Severo-Kurilsk on a number of occasions including April 30 and May 1. Ash fall was recorded in other settlements as well: Podgorny on May 16, and in Shelekhov on May 27 (fig. 31). Reports of eruptive activity diminished into the summer months. During the week of June 23, only gas and steam were reported above the volcano. KVERT downgraded Chikurachki to YELLOW on July 4 and GREEN on July 11 . The exact end of the eruption is not precisely known. Because of its remoteness, little is known in detail about the character and local impacts of this phase of eruptive activity, however it appears quite similar to the brief eruption of 2002 (Schneider and others, 2003; Neal and others, 2005.)

Chikurachki is the highest volcano on Paramushir Island in the northern Kuriles. Direct information about the volcano is limited and intermittent because it is not monitored seismically, 
and few people live nearby. Situated $105 \mathrm{~km}$ (65 mi) southwest of the tip of the Kamchatkan Peninsula, the volcanic cone of Chikurachki is distinctively red due to the abundance of oxidized basaltic andesite scoria on its upper flanks (fig. 19; Gorshkov, 1970; Simkin and Siebert, 1994). There are at least 6 known historical eruptions attributed to Chikurachki, including its largest historical eruption of $\sim 1 \mathrm{~km}^{3}\left(0.24 \mathrm{mi}^{3}\right)$ of material in 1853 . Prior to 2002 , its most recent eruption was in 1986 producing lava flows, pyroclastic avalanches, and significant local tephra accumulation (Ovsyannikov and Muraviev, 1992). 


\section{REFERENCES}

Belousov, A. and Belousov, M., 2001, Eruptive process, effects, and deposits of the 1996 and the ancient basaltic phreatomagmatic eruptions in Karymsky lake, Kamchatka, Russia: Spec. Publications International Association of Sedimentology, v. 30, p. 35-60.

Belousov, A., Voight, B., Belousova M., and Petukhin, A., 2002, Pyroclastic surges and flows from the 8-10 May 1997 explosive eruption of Bezymianny volcano, Kamchatka, Russia, Bulletin of Volcanology, v.64, p. 455-471.

Bogoyavlenskaya G.E., Braitseva O.A., Melekestsev I.V., Kiriyanov V.Yu. and C. Dan Miller., 1985, Catastrophic eruptions of the directed-blast type at Mount St. Helens, Bezymianny and Shiveluch volcanoes. Journal of Geodynamics, v. 3, p. 189-218.

Dixon, J.P., Stihler, S.D., Power J.A., Tytgat, G., Moran, S.C., Sánchez, J., Estes, S., McNutt, S.R., Paskievitch, J., 2004, Catalog of Earthquake Hypocenters at Alaska Volcanoes: January 1 - December 31, 2003: U.S. Geological Survey Open-file Report 2004-1234, 59p.

Fierstein, J., and Hildreth, E.W., 2000, Preliminary Volcano-Hazard Assessment for the Katmai Volcanic Cluster, Alaska: U.S. Geological Survey Open-File Report 00-489, 50 p.

Girina, O.A., Bogoyavlenskaya, G.E., and Demyanchuk, Yu. V., 1993, Bezymianny eruption of August 2, 1989: Volcanology and Seismology, v. 15, no. 2, p. 135-144 (in Russian).

Gorshkov G.S., 1970 Volcanism and the Upper Mantle; Investigations in the Kurile Island Arc. New York: Plenum Publishing Corp, 385 p.

Hildreth, W. Lanphere, M.A., Fierstein, J. 2003, Geochronology and eruptive history of the Katmai volcanic cluster, Alaska Peninsula: Earth and Planetary Science Letters, v. 214, p. 93-114.

Ivanov, B., Braitseva, O.A., and Zubin, M.I., 1991, Karymsky Volcano, Chapter 21 in: Active Volcanoes of Kamchatka, S.A. Fedotov and Yu. P. Masurenkov, (eds.), Moscow Nauka Publishers (Moscow), volume 2, p. 202-203.

Khrenov, A.P., Dvigalo, V.N., Kirsanov, I.T., Fedotov, S.A., Gorel'chik, V.I., and Zharinov, N.A., 1991, Klyuchevskoy Volcano, Chapter 6 in: Active Volcanoes of Kamchatka, S.A. Fedotov and Yu. P. Masurenkov, (eds.), Moscow Nauka Publishers (Moscow), volume 1, p. 146-163.

Kennedy, G.C., and Waldron, H.H., 1955, Geology of Pavlof Volcano and vicinity, Alaska: U.S. Geological Survey Bulletin 1028-A, 19 p.

Kirianov, V.Y., Neal, C.A., Gordeev, E.I., and Miller, T.P., 2002, KVERT (Kamchatkan Volcanic Eruptions Response Team): USGS Fact Sheet 064-02 in English and Russian. Also online: http://geopubs.wr.usgs.gov/fact-sheet/fs064-02/. 
Lu, Z., Wicks, Jr., C. Power, J.A., Dzurisin, D., 2000, Ground deformation associated with the March 1996 earthquake swarm at Akutan volcano, Alaska, revealed by satellite radar interferometry: Journal of Geophysical Research, v. 105, n. B9, p. 21,483-21,496.

McGimsey, R.G., Richter, D.H., DuBois, G.D., and Miller, T.P., 1992, A postulated new source for the White River Ash, Alaska, in Bradley, D.C., and Ford, A.B., eds., Geologic studies in Alaska by the U.S. Geological Survey, 1990: U.S. Geological Survey Bulletin 1999, p. 212-218.

McGimsey, R.G., and Neal, C.A., 1996, 1995 Volcanic activity in Alaska: Summary of events and response of the Alaska Volcano Observatory: U.S. Geological Survey Open-File Report 96$738,22 \mathrm{p}$.

McGimsey, R.G., Neal, C.A., and Doukas, M.P., 1995, Volcanic activity in Alaska: Summary of events and response of the Alaska Volcano Observatory 1992: U.S. Geological Survey OpenFile Report OF 95-83, 26 p.

McGimsey, R.G., and Wallace, K.1999, 1997 Volcanic Activity in Alaska and Kamchatka: Summary of events and response of the Alaska Volcano Observatory: U.S. Geological Survey OpenFile Report 99-448, 42 p.

McGimsey, R.G., Neal, C.A., and Girina, O., 2004, 1999 volcanic activity in Alaska and Kamchatka: Summary of events and response of the Alaska Volcano Observatory: U.S. Geological Survey Open-File Report 2004-1033, 45p.

McGimsey, R.G., Neal, C.A., and Girina, O., 2005, 2001 Volcanic activity in Alaska and Kamchatka: Summary of events and response of the Alaska Volcano Observatory: U.S. Geological Survey Open-File Report 2004-1453, 53 p.

Miller, T.P., McGimsey, R.G., Richter, D.H., Riehle, J.R., Nye, C.J., Yount, M.E., and Dumoulin, J.A., 1998, Catalog of the historically active volcanoes of Alaska: U.S. Geological Survey OpenFile Report 99-448, 42 p.

Miller, T.P., and Casadevall, T. C., 2000, Volcanic Hazards to Aviation, Part VII in Encyclopedia of Volcanoes, Academic Press, H. Sigurdsson, editor, p. 915-930.

Miller, T.P., and Chouet, B.A., 1994, The 1989-1990 eruptions of Redoubt Volcano: An introduction, in Miller, T.P., and Chouet, B.A., eds., Journal of Volcanology and Geothermal Research Special Issue, v. 62, nos. 1-4, p. 1-10.

Neal, C.A., Doukas, M.P., and McGimsey, R.G., 1995, 1994 volcanic activity in Alaska: Summary of events and response of the Alaska Volcano Observatory: U.S. Geological Survey OpenFile Report 95-271, 18 p. 
Neal, Christina, and McGimsey, R. G., 1997, 1996 volcanic activity in Alaska and Kamchatka: Summary of events and response of the Alaska Volcano Observatory: U.S. Geological Survey Open-File Report OF 97-0433, 34 p.

Neal, C.A., McGimsey, R.G., and Girina, O., 2005, 2002 Volcanic activity in Alaska: Summary of events and response of the Alaska Volcano Observatory: U.S. Geological Survey Open-File Report 04-1058, $51 \mathrm{p}$.

Neal, Christina A., 2003, Kamchatka Volcanic Eruption Team Celebrates Tenth Anniversary at Workshop, meeting report in EOS, Transactions of the American Geophysical Union, v. 84, n. 41, p. 427.

Nye, C.J., 1991, Mount Wrangell, in: Volcanoes of North America, Wood, C.A., and Kienle, J., eds., Cambridge University Press, p. 89-89.

Nye, C.J., Keith, T.E.C., Eichelberger, J.C., Miller, T.P., McNutt, S.R., Moran, S., Schneider, D.J., Dehn, J., and Schaefer, J.R., 2002, The 1999 eruption of Shishaldin Volcano, Alaska; monitoring a distant eruption: Bulletin of Volcanology, v. 64, no. 8, p. 507-519.

Ovsyannikov A.A and Muraviev Ya. D., 1992, Chikurachki eruption in 1986. Volcanology and Seismology, n.5-6, p. 3-20 (in Russian).

Ponomareva, V.V., Pevzner, M.M., and Melekestsev, I.V., 1998, Large debris avalanches and associated eruptions in the Holocene eruptive history of Shiveluch Volcano, Kamchatka, Russia, Bulletin of Volcanology, v. 59, n. 7, p. 490-505.

Richter, D.H., Preece, S.J., McGimsey, R.G., and Westgate, J.A., 1995a, Mount Churchill, Alaska: source of the late Holocene White River Ash: Canadian Journal of Earth Science, v. 32, p. 741-748.

Richter, D.H., Rosenkrans, D.S., and Steigerwald, M.J., 1995b, Guide to the volcanoes of the western Wrangell Mountains, Alaska: U.S. Geological Survey Bulletin 2072, 31 p.

Richter, D.H., Waythomas, C.F., McGimsey, R.G., and Stelling, P.L., 1998, Geologic map of Akutan Island, Alaska: U.S. Geological Survey Open-File Report 98-135, 22 p. + plate.

Schneider, D.J. Girina, O.A., Neal, C.A., Kotenko, L., Terentiev, N.S., Izbekov, P., Belousov, I., Senyukov, S., and Ovsyannikov, A.A., 2003, 2003 Eruption of Chikurachki Volcano, Paramushir Island, Northern Kuriles, Russia, (abs), Eos Trans. AGU, 84(46), Fall Meet. Suppl., Abstract V42B-0348, 2003

Simkin, T., and Siebert, L., 1994, Volcanoes of the world, Tucson, Arizona, Geoscience Press, Inc., $349 \mathrm{p}$. 
Till, A.B., Yount, M.E., and Riehle, J.R., 1993, Redoubt Volcano, southern Alaska: A hazard assessment based on eruptive activity through 1968: U.S. Geological Survey Bulletin 1996, 19 p.

Waythomas, C.F., and Miller, T.P., 1999, Preliminary volcano-hazard assessment for Iliamna Volcano, Alaska: U.S. Geological Survey Open-File Report OF 99-0373, 31 p., 1 sheet, scale unknown.

\section{ACKNOWLEDGEMENTS}

Andy Calvert and Jennifer Adleman graciously reviewed this report. Christy Severtson skillfully prepared the final layout for both hard copy and web posting. We thank Sergey Senyukov for assistance with Kamchatka volcano images. 
Table 1. Summary of 2003 VOLCANIC ACTIVITY in Alaska, including actual eruptions, possible eruptions, and unusual increases in fumarolic activity. Location of volcanoes shown in Figure 1.

\begin{tabular}{|l|l|l|}
\hline Volcano & Date of Activity & Type of Activity \\
\hline Veniaminof Volcano & $\begin{array}{l}\text { September 10, 2002 through mid- } \\
\text { April, 2003 }\end{array}$ & $\begin{array}{l}\text { Increase in seismicity, steam } \\
\text { and ash clouds reported }\end{array}$ \\
\hline
\end{tabular}

Table 2. Summary of SUSPECT VOLCANIC ACTIVITY (SVA) in 2003.

[SVA is defined as a report of eruption or possible eruption that is found to be normal fumarolic activity or non-volcanic phenomena, such as weather related. Location of volcanoes shown in Figure 1.]

\begin{tabular}{|l|l|l|}
\hline Volcano & Date of Activity & Type of Activity \\
\hline Wrangell volcano & June 13, 2003 & $\begin{array}{l}\text { Anomalous steam clouds } \\
\text { reported }\end{array}$ \\
\hline Redoubt Volcano & November 25, 2003 & $\begin{array}{l}\text { Anomalous steam cloud } \\
\text { reported }\end{array}$ \\
\hline Iliamna Volcano & July 25, 2003 & Avalanche of snow and ice \\
\hline Augustine volcano & September 9, 2003 & Report of increased steaming \\
\hline Katmai Group [Mt. Mageik] & $\begin{array}{l}\text { February 15, 2003; dust } \\
\text { cloud }\end{array}$ & $\begin{array}{l}\text { Reports of steaming; cloud of } \\
\text { resuspended ash mistaken for erup- } \\
\text { tion plume }\end{array}$ \\
\hline Pavlof Volcano & March 16, 2003 & Eruption reported; none detected \\
\hline Emmons Lake Caldera [Hague] & July 7, 2003 & Crater lake drains; refills \\
\hline Shishaldin Volcano & January 31, 2003 & Steam plumes \\
\hline Akutan Volcano & October 15,2003 & Anomalous steam plume \\
\hline Un-named source & February 2,2003 & Suspected ash cloud \\
\hline
\end{tabular}


Table 3. Summary of VOLCANIC ACTIVITY on Kamchatka Peninsula and the northern Kurile Island of Paramushir, Russia, 2003. Location of volcanoes shown in Figure 23.

\begin{tabular}{|l|l|l|}
\hline Volcano & Date of Activity & Type of Activity \\
\hline Sheveluch Volcano & Intermittently throughout the year. & $\begin{array}{l}\text { Lava dome growth, short-lived, } \\
\text { explosive episodes send ash as } \\
\text { high as } 8.5 \mathrm{~km}(\sim 28,000 \mathrm{ft}), \text { pyro- } \\
\text { clastic flows, localized ash fall, } \\
\text { one damaging lahar. }\end{array}$ \\
\hline Klyuchevskoy Volcano & Intermittently throughout the year. & $\begin{array}{l}\text { Elevated seismicity, ash explo- } \\
\text { sions, onset of intermittent strom- } \\
\text { bolian activity in mid-May. }\end{array}$ \\
\hline Bezymianny Volcano & $\begin{array}{l}\text { Early January and July 26 into } \\
\text { early August }\end{array}$ & $\begin{array}{l}\text { Late 2002 dome growth episode } \\
\text { continues into early 2003; explo- } \\
\text { sive dome collapse }\end{array}$ \\
\hline Karymsky Volcano & Intermittently throughout the year. & $\begin{array}{l}\text { Periods of increased seismicity } \\
\text { intensification of vulcanian } \\
\text { and strombolian explosions, } \\
\text { avalanches, degassing. }\end{array}$ \\
\hline Chikurachki Volcano & 18 April through mid-June, 2003 & $\begin{array}{l}\text { Strombolian/vulcanian eruption, } \\
\text { ash plumes, ash fall on Paramushir } \\
\text { Island }\end{array}$ \\
\hline
\end{tabular}

Table 4. Summary of SUSPECT VOLCANIC ACTIVITY on the northern Kurile Island of Atlasova, Russia, 2003. Location shown in Figure 22.

\begin{tabular}{|l|l|l|}
\hline Volcano & Date of Activity & Type of Activity \\
\hline Alaid Volcano & October through November 2003 & $\begin{array}{l}\text { Seismic tremor later interpreted to } \\
\text { be storm noise }\end{array}$ \\
\hline
\end{tabular}


Table 5. Chronology of modern seismic and other monitoring of Kamchatka as of December 2003.

[Compiled by Sergey Senyukov, Kamchatka Experimental and Methodical Seismology Department (KEMSD), and Tina Neal, Alaska Volcano Observatory. *Prior to 1979, other Institutes maintained programs of volcano monitoring in Kamchatka (a partial listing includes: 19611971, Pacific Seismological Department of Institute of Earth Physics; 1972 - 1978 - Institute of Volcanology)]

\begin{tabular}{|c|c|c|}
\hline VOLCANO & $\begin{array}{l}\text { APPROXIMATE START } \\
\text { DATE OF CONTINUOUS } \\
\text { SEISMIC MONITORING BY } \\
\text { KEMSD* }\end{array}$ & $\begin{array}{l}\text { OTHER MONITORING } \\
\text { TECHNIQUES } \\
\text { USED ROUTINELY }\end{array}$ \\
\hline Sheveluch & $\begin{array}{l}\text { Seismic station-12.02.1987; } \\
\text { Telemetered data-1980; } \\
\text { Digital format-Sep.1996; } \\
\text { Near-real time processing_1999. }\end{array}$ & $\begin{array}{l}\text { Near real-time video system (2002); } \\
\text { direct observation from nearby } \\
\text { Klyuchi; satellite imagery }\end{array}$ \\
\hline Klyuchevskoy & $\begin{array}{l}\text { Seismic station-1961; } \\
\text { Telemetered data-01.09.1987; } \\
\text { Digital format-Sep.1996; } \\
\text { Near-real time processing-1999. }\end{array}$ & $\begin{array}{l}\text { Near real-time video system (2000); } \\
\text { direct observation from nearby } \\
\text { Klyuchi and Kozyrevsk; satellite } \\
\text { imagery }\end{array}$ \\
\hline Bezymianny & $\begin{array}{l}\text { Seismic station-1961; } \\
\text { Telemetered data-31.10.1988; } \\
\text { Digital format-Sep.1996; } \\
\text { Near-real time processing-1999. }\end{array}$ & $\begin{array}{l}\text { Near real-time video system (2003); } \\
\text { direct observation from nearby } \\
\text { Kozyrevsk; satellite imagery }\end{array}$ \\
\hline Plosky Tolbachik & $\begin{array}{l}\text { Seismic station-12.01.1977; } \\
\text { Telemetered data-10.11.1990; } \\
\text { Digital format-Sep.1996; } \\
\text { Near-real time processing-1999. }\end{array}$ & $\begin{array}{l}\text { Direct observation from nearby } \\
\text { Kozyrevsk; satellite imagery }\end{array}$ \\
\hline Karymsky & $\begin{array}{l}\text { Telemetered data-Sep. 1989; } \\
\text { Digital format-Jan.1996; } \\
\text { Near-real time processing-1996. }\end{array}$ & Field observation; satellite imagery \\
\hline Koryaksky & $\begin{array}{l}\text { Seismic station-Apr.1963; } \\
\text { Telemetered data-July 1975; } \\
\text { Digital format-Jan.1996; } \\
\text { Near-real time processing_-1996. }\end{array}$ & $\begin{array}{l}\text { Direct observation from PK; satellite } \\
\text { imagery }\end{array}$ \\
\hline Avachinsky & $\begin{array}{l}\text { Seismic station_Apr.1963; } \\
\text { Telemetered data_July 1976; } \\
\text { Digital format_Jan.1996; } \\
\text { Near-real time processing_-1997. }\end{array}$ & $\begin{array}{l}\text { Direct observation from PK; satellite } \\
\text { imagery }\end{array}$ \\
\hline Gorely & $\begin{array}{l}\text { Telemetered data_-July } 1980 ; \\
\text { Digital format—Jan.1996; } \\
\text { Near-real time processing_-1996. }\end{array}$ & $\begin{array}{l}\text { Direct observation from PK; satellite } \\
\text { imagery }\end{array}$ \\
\hline Mutnovsky & $\begin{array}{l}\text { Telemetered data_July 1980; } \\
\text { Digital format—Jan.1996; } \\
\text { Near-real time processing_-1996. }\end{array}$ & $\begin{array}{l}\text { Direct observation from PK; satellite } \\
\text { imagery }\end{array}$ \\
\hline Alaid & $\begin{array}{l}\text { Telemetered data, digital format, near- } \\
\text { real time processing-Aug. } 2001 \text {. }\end{array}$ & Satellite imagery \\
\hline
\end{tabular}


Table 6. Level of Concern Color Code for volcanic activity.

\section{LEVEL OF CONCERN COLOR CODE}

To more concisely describe our level of concern about possible or ongoing eruptive activity at an Alaskan volcano, the Alaska Volcano Observatory uses the following color-coded classification system. Definitions of the colors reflect AVO's interpretations of the behavior of the volcano. Definitions are listed below followed by general description of typical activity associated with each color.

\begin{tabular}{c|l} 
GREEN & $\begin{array}{l}\text { No eruption anticipated. } \\
\text { Volcano is in quiet, "dormant" state. }\end{array}$ \\
\hline YELLOW & $\begin{array}{l}\text { An eruption is possible in the next few weeks and may occur with little or no } \\
\text { additional warning. } \\
\text { Small earthquakes detected locally and (or) increased levels of volcanic gas emissions. }\end{array}$ \\
\hline ORANGE & $\begin{array}{l}\text { Explosive eruption is possible within a few days and may occur with little or no } \\
\text { warning. Ash plume(s) not expected to reach } 25,000 \text { feet above sea level. } \\
\text { Increased numbers of local earthquakes. Extrusion of a lava dome or lava flows } \\
\text { (non-explosive eruption) may be occurring. }\end{array}$ \\
\hline RED & $\begin{array}{l}\text { Major explosive eruption expected within } 24 \text { hours. Large ash plume(s) expected } \\
\text { to reach at least } 25,000 \text { feet above sea level. } \\
\text { Strong earthquake activity detected even at distant monitoring stations. Explosive } \\
\text { eruption may be in progress. }\end{array}$ \\
\hline
\end{tabular}




\title{
GLOSSARY OF SELECTED TERMS
}

\author{
AAWA: \\ "Alaskan Aviation Weather Unit"
}

ADT:

"Alaska Daylight Time"

AEIC:

"Alaska Earthquake Information Center"

ASL:

"above sea level"

AST:

"Alaska Standard Time"

AVO:

"Alaska Volcano Observatory"

\section{AVHRR:}

“Advanced Very High Resolution Radiometer"; AVHRR provides one form of satellite imagery

andesite:

volcanic rock composed of about 53 to 63 percent silica $\left(\mathrm{SiO}_{2}\right.$, an essential constituent of most minerals found in rocks)

ash:

fine fragments (less than 2 millimeters across) of lava or rock formed in an explosive volcanic eruption

\section{basalt:}

general term for dark-colored igneous rock, usually extrusive, containing about 45 to 52 weight percent silica $\left(\mathrm{SiO}_{2}\right.$, an essential constituent of most minerals found in rocks)

\section{bomb:}

boulder-size chunk of partly solidified lava explosively ejected from a volcano

caldera:

a large, roughly circular depression usually caused by volcanic collapse or explosion

\section{CAVW:}

Smithsonian Institute's "Catalog of Active Volcanoes of the World" 


\section{cinder cone:}

small, steep-sided conical hill built mainly of cinder, spatter, and volcanic bombs

\section{COSPEC:}

"Correlation Spectrometer"; device for measuring sulfur dioxide emissions

\section{CWSU}

"Center Weather Service Unit"

\section{FAA:}

"Federal Aviation Administration"

\section{fallout:}

a general term for debris which falls to the earth from an eruption cloud

\section{fault:}

a fracture or zone of fractures along which there has been displacement of the sides relative to one another

\section{FIR:}

"Flight Information Region"

\section{FLIR}

"Forward Looking Infrared Radiometer"; used to delineate objects of different temperature

\section{fissure:}

a roughly linear or sinuous crack or opening on a volcano; a type of vent which commonly produces lava fountains and flows

\section{fumarole:}

a small opening or vent from which hot gases are emitted

glaciolacustrine:

pertaining to sediments deposited in glacial lakes, and resulting landforms

\section{GMS:}

"Geostationary Meteorological Satellite"

\section{GVN:}

"Global Volcanism Network"

\section{Holocene:}

geologic epoch extending from the last present to 10,000 years ago 


\section{incandescent:}

glowing red or orange due to high temperature

intracaldera:

refers to something within the caldera

\section{IVGG:}

Russian "Institute of Volcanic Geology and Geochemistry"

JMA:

"Japanese Meteorological Agency"

\section{KDT:}

"Kamchatkan Daylight Time", which = ADT + 21 hrs.

KEMSD:

Russian "Kamchatka Experimental and Methodical Seismology Department"

KST:

"Kamchatkan Standard Time", which = AST + 21 hrs.

KVERT:

Russian "Kamchatkan Volcano Eruption Response Team”

lava:

when molten material reaches the earth's surface, it is called lava

magma:

molten material below the surface of the earth

MODIS:

Satellite-based"Moderate Resolution Imaging Spectroradiometer"

NOAA:

"National Oceanic and Atmospheric Administration"

NOPAC:

"North Pacific Air Corridor"

\section{NOTAM:}

"Notice to Airmen", a notice containing information [not known sufficiently in advance to publicize by other means] concerning the establishment, condition, or change in any component [facility, service, or procedure of , or hazard in the National Airspace System] the timely knowledge of which is essential to personnel concerned with flight operations 


\section{NWS:}

"National Weather Service"

\section{phreatic activity:}

an explosive eruption caused by the sudden heating of ground water as it comes in contact with hot volcanic rock or magma

\section{phreatic ash:}

fine fragments of volcanic rock expelled during phreatic activity; this ash is usually derived from existing rock and not from new magma

\section{PIREP:}

"Pilot Weather Report-A report of meteorological phenomena encountered by aircraft in flight

\section{pixel:}

contraction of "picture element". A pixel is one of the many discrete rectangular elements that form a digital image or picture on a computer monitor or stored in memory. In a satellite image, resolution describes the size of a pixel in relation to area covered on the ground. More pixels per unit area on the ground means a higher resolution.

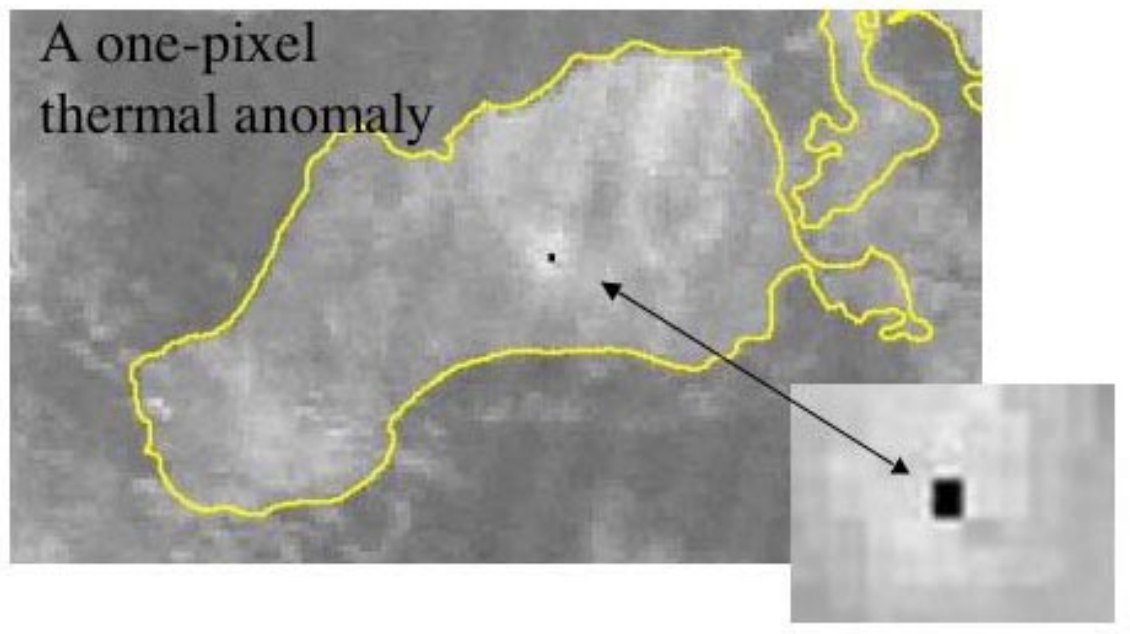

\section{PK:}

"Petropavlovsk-Kamchatsky", capital city of Kamchatka in the Russian Far East

\section{Pleistocene:}

geologic epoch extending from $2-3$ million years ago to approximately 10,000 years before present

regional earthquake:

earthquake generated by fracture or slippage along a fault; not caused by volcanic activity 
RFE:

"Russian Far East"

SAB:

"Synoptic Analysis Branch" of NOAA

SAR:

"Synthetic Aperture Radar"

satellite cone:

a subsidiary volcanic vent located on the flank of a larger volcano

seismic swarm:

a flurry of closely spaced earthquakes or other ground shaking activity; often precedes an eruption

\section{shield volcano:}

a broad, gently sloping volcano usually composed of fluid, lava flows of basalt composition (for example, Mauna Loa, Hawaii)

SIC:

"Scientist-in-Charge"; top management of a volcano observatory

SIGMET:

"Significant Meteorological information statement", issued by FAA

spectrogram:

a graphic depiction of seismic amplitude in different frequency bands

Spurr 13-May-2005 14:39:08 UT

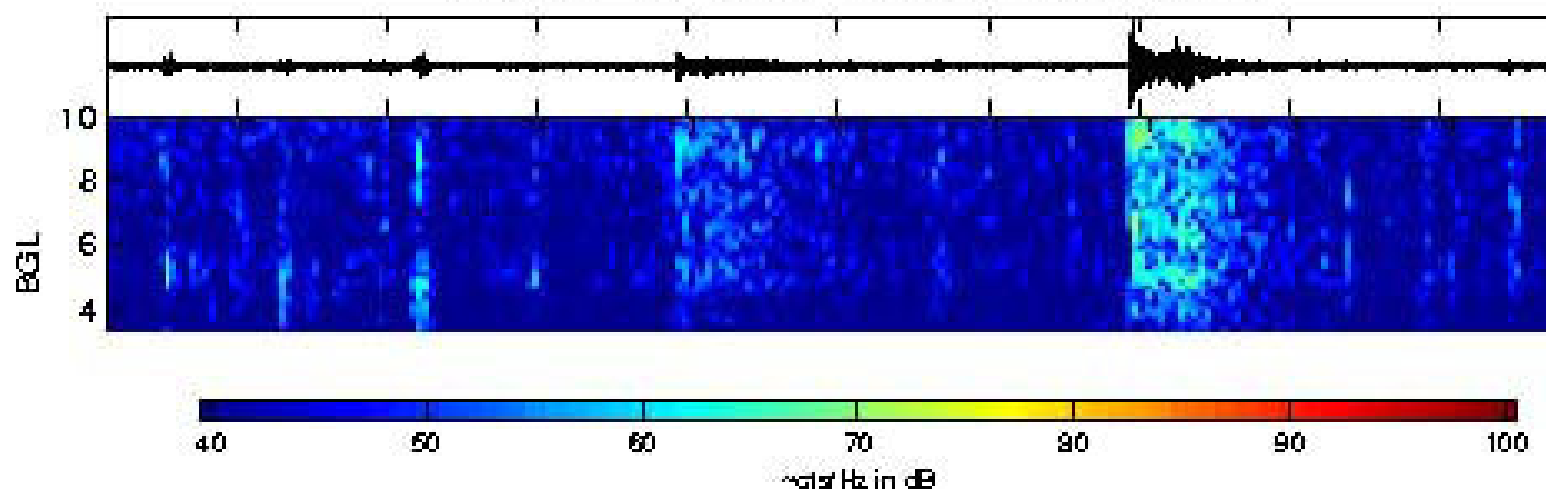

stratovolcano:

(also called a stratocone or composite cone) a steep-sided volcano, usually conical in shape, built of interbedded lava flows and fragmental deposits from explosive eruptions 


\section{strombolian:}

type of volcanic eruption characterized by intermittent bursts of fluid lava, usually basalt, from a vent or crater as gas bubbles rise through a conduit and burst at the surface

\section{subplinian:}

style of explosive eruptions characterized by vertical eruption columns and widespread dispersal of tephra

\section{SVA:}

"suspect volcanic activity"

\section{tephra:}

a general term covering all fragmental material expelled from a volcano (ash, bombs, cinders, etc.)

\section{TFR:}

“Temporary Flight Restriction”, issued by FAA

\section{USCG:}

"U.S. Coast Guard"

\section{USGS:}

"U.S. Geological Survey"

UTC:

"Coordinated Universal Time”; same as Greenwich Mean Time (GMT)

\section{VAAC:}

"Volcanic Ash Advisory Center"

vent:

an opening in the earth's surface through which magma erupts or volcanic gasses are emitted

volcano-tectonic earthquakes:

earthquakes generated within a volcano from brittle rock failure resulting from strain induced by volcanic processes

VTTS:

"Valley of Ten Thousand Smokes"in Katmai National Park and Preserve

\section{UAFGI:}

"University of Alaska Fairbanks Geophysical Institute" 


\section{webicorder:}

computer simulation of a drum seismograph, based on digital seismic data, posted to AVO's internal website

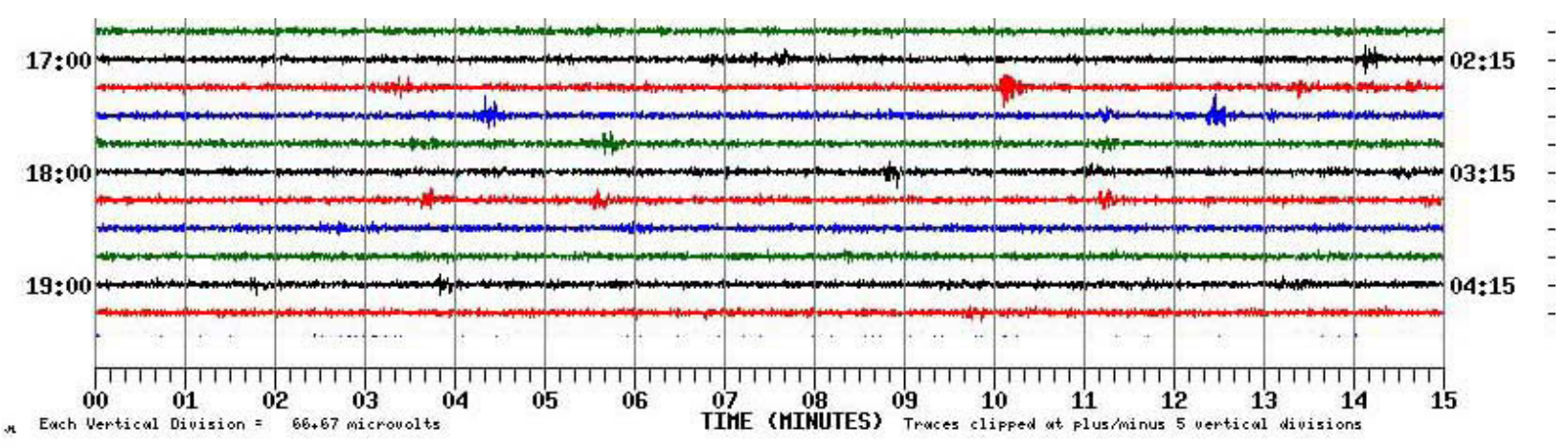

